\title{
Development of new membrane materials for direct methanol fuel cells
}


This research was financially supported by The Dutch Technology Foundation STW (project number: 5713).

Development of new membrane materials for direct methanol fuel cell

Ph.D. Thesis, University of Twente

ISBN: 978-90-365-2811-5

(C) Mustafa Hakan Yildirim, Enschede (The Netherlands), 2009

No part of this work may be reproduced by print, photocopy or any other means without permission of the author.

Cover design by Tugba-Hakan YILDIRIM

Printed by Wöhrmann Print Service 


\title{
DEVELOPMENT OF NEW MEMBRANE MATERI ALS FOR DI RECT METHANOL FUEL CELLS
}

\author{
DISSERTATION
}

to obtain

the degree of doctor at the University of Twente, on the authority of the rector magnificus, prof. dr. H. Brinksma, on account of the decision of the graduation committee, to be publicly defended

on Friday $20^{\text {th }}$ of March 2009 at 13:15

by

\section{Mustafa Hakan Yildirim}

born on $5^{\text {th }}$ of November 1979

in Ankara, Turkey 
This dissertation has been approved by:

Promoter:

Assistant-promoter:
Prof. Dr.-Ing. M. Wessling

Dr.D.F. Stamatialis 
Esime ve aileme 



\section{CONTENTS}

Chapter 1: Introduction

Chapter 2: Dimensionally stable Nafion ${ }^{\circledR}$-polyethylene composite membranes for direct methanol fuel cell applications

Chapter 3: Impregnated membranes for direct methanol fuel cells at high methanol concentrations

Chapter 4: Nafion $^{\circledR} /$ H-ZSM-5 composite membranes with superior performance for direct methanol fuel cells

Chapter 5: Micro-structured Nafion ${ }^{\circledR}$ membranes for direct methanol fuel cell applications 



\section{Chapter 1}

\section{Introduction}

The development of fuel cells started around $19^{\text {th }}$ century with the wish to convert the chemical energy of fossil fuels directly into electricity. After about hundred years of research, many types of fuel cells have been developed [1]. This chapter explains the historic trends of fuel cell research and also gives a short overview on different types of fuel cells. The main focus of this thesis is the direct methanol fuel cell. Therefore, an overview on the working principle and materials employed for DMFC are described. At the end of the chapter scope and structure of this thesis are presented.

\section{The historic trends}

Experiments with fuel cells started around 1839 when researchers tried to oxidize coal and coal gas electrochemically in 'piles'. During the period from 1920 till the Second World War more research was done and some practical fuel cells were built. But due to material problems causing short operating life times, fuel cells were not economically feasible [1]. In the 1960s researchers regained interest in fuel cells, resulting in an alkaline fuel cell system with porous metal electrodes which was used in the spacecraft which enabled men to fly to the moon in 1968. Besides, electrical automobiles propelled by fuel cells started to be developed. The first hybrid vehicle for four passengers with a hydrogen fuel cell was built in 1970 [1]. In the mid-1970s, fuel cells were developed which were used for power generation in large scale power plants (up to $10 \mathrm{MW}$ ). The strive for fuel cells with higher efficiencies resulted in the development of the molten carbonate fuel cell (MCFC) in the 1980s and the solid oxide fuel cell (SOFC) in the 1990s. A new development started in the 1990s when membranes came into the picture for the use in fuel cells. This resulted in high power densities and increasing life expectations for fuel cells.

\section{General aspects of fuel cells}

The definition of a fuel cell is: "An electrochemical cell which can continuously convert the chemical energy of a fuel and an oxidant to electrical 
energy by a process involving an essentially invariant electrode-electrolyte system" [1]. The basic principles of an electrochemical battery can be compared with the principles of a fuel cell. The only difference is that in a fuel cell, the chemical energy is stored outside the cell, while in batteries the fuel is stored inside the cell.

Electrical power generation by conventional methods is less efficient, for example extra conversion steps are needed to convert chemical energy via heat energy and kinetic energy into electrical energy. Fuel cells can obtain efficiencies up to $60 \%$ of the containing energy by converting chemical energy into power and heat [1].

\section{Types of fuel cells}

Fuel cell systems can be classified in different ways: working temperature, the pressure of operation, kind of fuel and/or oxidant used or type of electrolyte. In this chapter the fuel cells will be distinguished by the latter and a short description will be given.

\section{Alkaline Fuel Cell (AFC)}

The Alkaline Fuel Cell uses $\mathrm{H}_{2}$ as fuel and $\mathrm{O}_{2}$ as oxidant. $35-45 \% \mathrm{KOH}$ is used as an electrolyte. Charge carrier is the $\mathrm{OH}^{-}$ions. A big disadvantage is that $\mathrm{CO}_{2}$ can permeate through the electrolyte, so only pure $\mathrm{H}_{2}$ and $\mathrm{O}_{2}$ can be used [1].

\section{Molten Carbonate Fuel Cell (MCFC)}

This type of fuel cell operates at very high temperatures of about $600-700$ ${ }^{\circ} \mathrm{C}$. At these temperatures the alkali carbonates, which are used as electrolyte, form a highly conductive molten salt in which carbonate ions provide ionic conduction. Noble metals are not required, because $\mathrm{Ni}$ (anode) and nickel oxide (cathode) can be used as catalysts [2].

\section{Solid Oxide Fuel Cell (SOFC)}

A SOFC operates at $650-1000{ }^{\circ} \mathrm{C}$ where ionic conduction by oxygen ions takes place. The electrolyte used is a solid, nonporous metal oxide, usually $\mathrm{Y}_{2} \mathrm{O}_{3}$ stabilized $\mathrm{ZrO}_{2}[2]$. 
Polymer Electrolyte Membrane Fuel Cell (PEMFC)

The main topic in this thesis is the Polymer Electrolyte Membrane (PEM). This is the electrolyte used in a PEMFC. In most PEMFCs, $\mathrm{H}_{2}$ is used as fuel. A product of this fuel cell is water. The main challenge is to control the evaporation of water. Because the membrane must be hydrated, the amount of water which is produced must be higher than the amount of water which is evaporated. Therefore, the operating temperature is usually less than $100^{\circ} \mathrm{C}$. A DMFC is a type of PEMFC. The characteristics of a DMFC will be explained in the next chapter.

\section{Direct Methanol Fuel Cell}

The direct methanol fuel cell (DMFC) produces electric power by direct conversion of liquid methanol and is therefore been called "the electrochemist's dream" and "the ideal fuel cell system" [3]. A DMFC combines the properties of direct hydrogen/air fuel cells with the advantages of a liquid fuel. Because it is a liquid, it can be transported and stored easily. Methanol needs no cryogenic container maintained at a temperature of $-253^{\circ} \mathrm{C}$. Methanol is cheap, plentiful and easy to manufacture. Moreover, it has a higher energy density than hydrogen [2].

\subsection{Working principle}

A DMFC consists of two electrodes (anode and cathode), two compartments where the oxidation and reduction take place and a proton exchange membrane (PEM) as shown in Figure 1. The fuel is fed to the anode compartment and oxidized in a half reaction that produces protons, electrons and $\mathrm{CO}_{2}$. The formed protons are transported through the PEM and the electrons run through electrical wires outside the cell to complete the circuit. The energy in the current that flows through the wires can be used to generate power. At the cathode compartment the oxidant, $\mathrm{O}_{2}$ or air, reacts with the protons and electrons to form water [1,2].

The membrane electrode assembly (MEA) is the heart of the fuel cell. The MEA consists of five parts. The diffusion layer is the first layer, an electrically conductive layer with an open structure. This layer, which is in contact with the fuel, improves the diffusion of the fuel to, and the decomposition products from the anode. Another function of this diffusion layer is to 
work as a current collector for the electrons released in the second layer of the MEA, the anode catalyst $(\mathrm{Pt}-\mathrm{Ru})$. The catalyst in this layer accelerates the decomposition of the fuel into electrons, protons and combustion products, usually $\mathrm{CO}_{2}$. The anode half reaction for a DMFC is given in Equation $1[1,2,4]$ :

$$
\mathrm{CH}_{3} \mathrm{OH}+\mathrm{H}_{2} \mathrm{O} \leftrightarrow \mathrm{CO}_{2}+6 \mathrm{H}^{+}+6 \mathrm{e}^{-}
$$

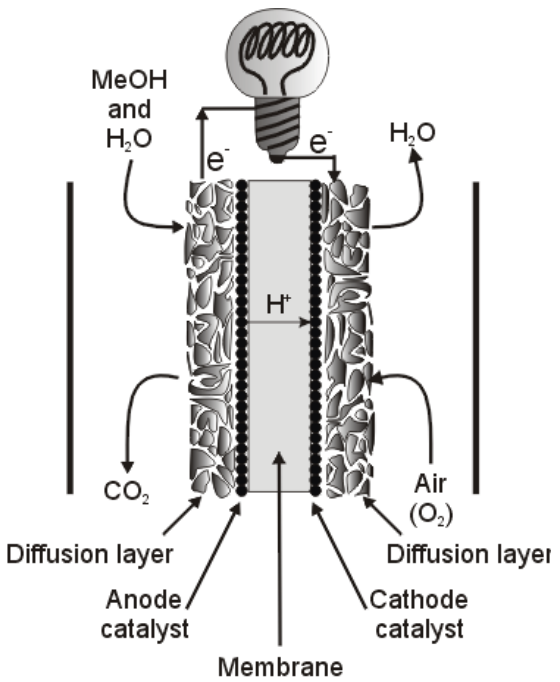

Figure 1. Schematic drawing of a direct methanol fuel cell.

The released protons diffuse through the electrolyte, the third layer. Because this layer is non conductive for electrons, the electrons must be transported externally through electrical wires. At the cathode catalyst, the fourth layer, the protons and electrons react with oxygen to form water, as can be seen in Equation 2. This reaction is usually accelerated by the catalyst platinum (Pt).

$$
\frac{3}{2} \mathrm{O}_{2}+6 \mathrm{H}^{+}+6 \mathrm{e}^{-} \leftrightarrow 3 \mathrm{H}_{2} \mathrm{O}
$$


The diffusion layer at the cathode compartment is used to transport the oxygen from the bulk gas phase. This fifth layer is also used to transport the water, which is formed at the cathode, to the bulk gas phase where it will be removed.

When the half reactions are combined, it can be seen in the overall reaction that methanol is combusted to water and carbon dioxide (see equation 3 ):

$$
\mathrm{CH}_{3} \mathrm{OH}+\frac{3}{2} \mathrm{O}_{2} \leftrightarrow 2 \mathrm{H}_{2} \mathrm{O}+\mathrm{CO}_{2}
$$

The Gibbs free energy of methanol and oxygen is much higher than those of water and carbon dioxide. As a result, the combustion of methanol is a spontaneous reaction with a Gibbs free energy difference of $-702,5 \mathrm{~kJ} / \mathrm{mol}$ under standard conditions at $25{ }^{\circ} \mathrm{C}$ [2]. This energy difference is used to generate electrical energy.

\subsection{DMFC performance losses}

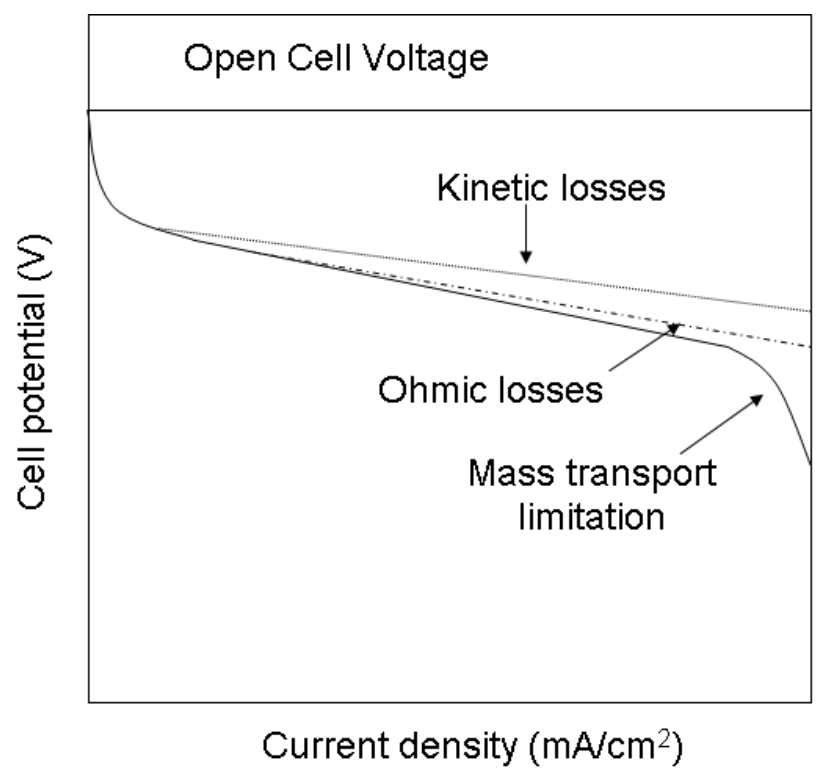

Figure 2. Typical polarization curve of a fuel cell. 
The performance of a fuel cell is usually determined by obtaining a polarization curve, where cell voltage is plotted as a function of current density. Naturally, a higher cell voltage at a specific current indicates better performance. However, we can also gain information from the polarization curve about factors that are affecting cell performance. Performance losses caused by slow kinetics, ohmic resistance and mass transport can all be diagnosed from a polarization curve. Figure 2 shows a typical polarization curve of a fuel cell. Also shown are the regions where kinetic, ohmic and mass transport losses occur. Kinetic losses are typical seen as a sharp drop in potential at low current densities due to slow electrode kinetics. Ohmic losses (i.e. from the membrane/electrode resistances) are usually observed in the linear region at intermediate current densities Mass transport losses, which is caused by the slow mass transport of the reactants at the electrode/electrolyte interface, can be diagnosed from sudden drops in potential at high current densities.

\subsection{Materials for DMFC}

Membrane electrode assembly (MEA) is the heart of DMFC and consists of a proton exchange membrane, catalyst layers and gas diffusion layers (GDLs). These components are fabricated individually and then pressed together at high temperatures and pressures [5]. Figure 3 illustrates transport through PEM fuel cell cathode.

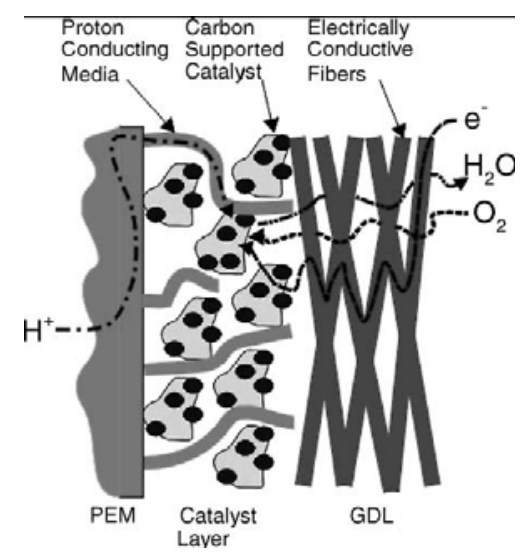

Figure 3. Transport of gases, protons, and electrons in a PEM fuel cell electrode (cathode) [5]. 
The interface between the membrane and electrode is critical, because the transport processes required for an operational fuel cell have to be balanced correctly. The three transport processes are:

1. transport of protons from the membrane to the catalyst;

2. transport of electrons from the current collector to the catalyst through the gas diffusion layer;

3. transport of the reactant and product gases to and from the catalyst layer and the gas channels.

In order to reduce transport losses, the three-phase contact of protons, electrons and gases has to be optimized. Therefore, the amount of volume in the catalyst layer between the transport media for each of the three phases needs to be correctly distributed. Above that, an intimate contact of all three phases at the catalyst particles is needed for effective operation of a PEM fuel cell $[1,2]$. The most used electrode design consists of a thin-film electrolyte (e.g. Nafion ${ }^{\circledR}$ ) and a diffusion layer made of woven or non-woven carbon cloths. The next chapters will give some more information on the components of a PEM fuel cell MEA.

\subsubsection{Catalyst layer}

As well as in the anode as in the cathode the catalyst layer is the location of the half-cell reaction and is therefore also referred to as the active layer. This layer is either applied to the membrane or to the gas diffusion layer. It is important, for effective operation of a fuel cell, that the catalyst particles (Pt or Pt alloys, shown as black ellipses in Figure 3 ) are placed within close proximity of the membrane. Catalyst loadings between $1-5 \mathrm{mg} / \mathrm{cm}^{2}$ are normally used in DMFC operation [6].

The catalysts accelerate the reactions by lowering the energy barrier between the reactants and products. As a result, the fuel cell can be operated at lower temperatures. A combination of platinum and ruthenium is normally used at the anode side. At the cathode side, only platinum is used as catalyst.

Because platinum is a very expensive material, high platinum loadings cause a major barrier to the commercialization of DMFCs. Therefore, much research is done to increase the utilization of the platinum that is depos- 
ited. The utilization can be increased by optimizing reactant diffusivity, ionic and electrical conductivity, and the level of hydrophobicity of the catalyst layer [5]. These properties have to be carefully balanced. Another factor which can be improved is the catalyst life time by decreasing the rate of poisoning of the catalyst.

\subsubsection{Gas diffusion layer}

The function of the gas diffusion layer is to ensure that reactants effectively diffuse to the catalyst layer. The GDL is the electrical conductor that transports electrons to and from the catalyst layer. Another function of the GDL is to facilitate the transport of methanol and the reaction products at the anode side. At the cathode side, the GDL has to facilitate the transport of water and oxygen.

Most used materials for GDLs are porous carbon paper or carbon cloth, with a thickness in the range of $100-300 \mu \mathrm{m}$ [5]. These materials are usually coated with Teflon $^{\circledR}$ to increase the hydrophobicity. This way, the GDL can partially control the hydration of the membrane by transporting water to the membrane. If water is not transported fast enough from cathode then that compartment can be flooded which causes a barrier for the oxygen to reach the cathode [7].

\subsubsection{Polymer electrolyte membrane}

Nafion ${ }^{\circledR}$ is an example of a homogenous perfluorinated ionomer membrane. The main advantages of perfluorinated membranes are the outstanding chemical stability and the high ionic conductivity. Disadvantages are the high price (US\$600-1200/ $\mathrm{m}^{2}$, [8]) and high methanol and water permeabilities. Nevertheless, Nafion ${ }^{\circledR}$ is the most widely used membrane in DMFCs (mainly as a reference material). Since its introduction in the 1960 s by DuPont, it is the standard material for PEMFC technology. Its chemical structure is shown in Figure 4. Its molecular weight has been estimated at $10^{5}$ $10^{6} \mathrm{Da}$ [9], but usually the equivalent weight (EW) and material thickness are used to describe it. The EW is defined as the weight of Nafion per mole of sulfonic acid group. The most used membrane in DMFC applications is Nafion ${ }^{\circledR} 117$ which represents $1100 \mathrm{EW}$ and 0.007 inch $(178 \mu \mathrm{m})$ in thickness. Membranes can also be described in terms of their ion exchange capacity (IEC) which is inversely proportional to the equivalent weight. 
Nafion ${ }^{\circledR}$ is a perfluorsulfonic acid membrane which possesses high proton conductivity of $90-120 \mathrm{mS} \mathrm{cm}^{-1}$ at $80{ }^{\circ} \mathrm{C}$ in the relative humidity (RH) range of $34-100 \%$ and has a good chemical as well as mechanical stability [10]. Nafion ${ }^{\circledR}$ is chemically inert in reducing and oxidizing environments due to the polytertrafluorethylene (PFTE)-based structure.

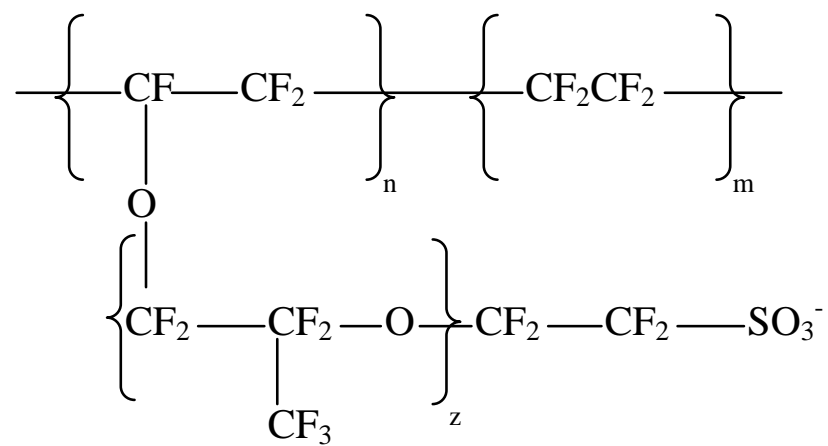

Figure 4. Chemical structure of Nafion ${ }^{\circledR}$ (based on a figure of [11]).

A very important property for membranes in fuel cells is the water uptake. According to the manufacturer, Nafion ${ }^{\circledR}$ membranes show an increase of about $10 \%$ in thickness and linear expansion when it is brought in contact with liquid water $\left(23^{\circ} \mathrm{C}\right)$. Due to the hydrophobic backbones and the hydrophilic end groups, a spontaneous phase separation takes place in the membrane [10]. Hydrophilic clusters are formed in the hydrated condition that are connected through water channels thereby forming a water network. The clusters contain the solvated $\mathrm{SO}_{3}^{-}$groups, water and cations. The configuration of these clusters minimizes the hydrophobic interaction of ions and water with the backbone as well as the electrostatic repulsion of close sulfonate groups as illustrated in Figure 5.

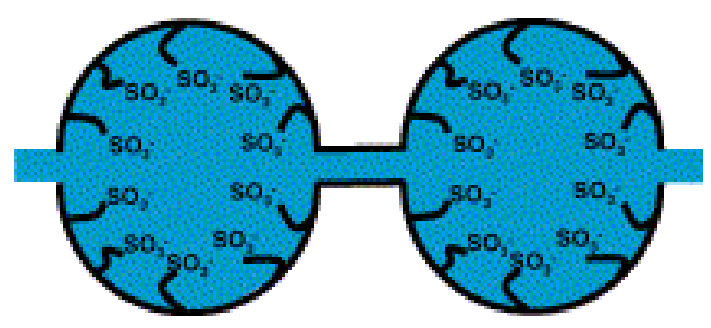

Figure 5. Cluster model ([11]). 
Because of this water filled network in a hydrophobic backbone, protons can be transported through these channels in $\mathrm{H}_{3} \mathrm{O}^{+}$form by Grotthuss diffusion (i.e. proton hopping). In this mechanism, a proton connects to a water molecule to form $\mathrm{H}_{3} \mathrm{O}^{+}$. Therefore, the membranes have to be hydrated. On the other side of the hydride ion, one of the other protons is released, which can form a bond with the next water molecule. In this way the acid group can diffuse very fast. A schematic of this process can be seen in Figure 6.

This mechanism explains the high proton conductivity of perfluorinated membranes. Also, the strong electrostatic interactions of the ionic clusters cause the high mechanical stability of the membrane.

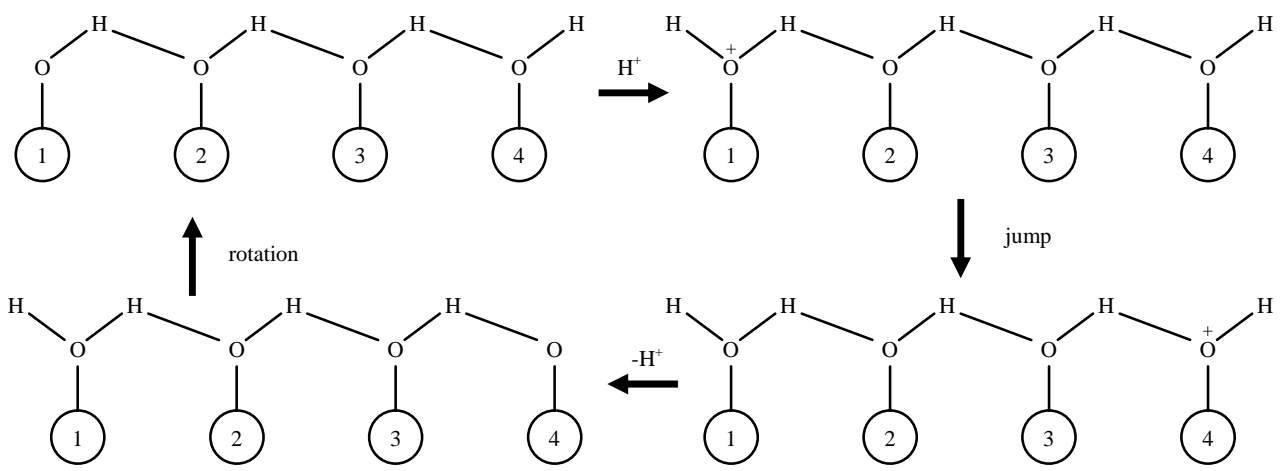

Figure 6. Grotthuss mechanism (adapted from [12]).

Proton transport through the membrane shows the same characteristics as in an aqueous solution. For every proton a shell of water is also transported through the membrane because of the electroosmotic water drag through the cell. Another factor influencing the water uptake in a membrane is the back diffusion of product water from the cathode into the membrane.

A big disadvantage of $\mathrm{Nafion}^{\circledR}$ for the DMFC application is the high methanol cross-over. The high methanol permeability reduces the efficiency of a DMFC substantially. Methanol permeation is associated with the high water content and the proton conduction mechanism [13]. This is because water and methanol can also be transported easily through the hydrophilic regions. Methanol crossover can be reduced by increasing the thickness or $\mathrm{EW}$ of the membrane, but this leads to higher voltage losses especially at 
higher current density operation [14]. The methanol crossover rate can also be reduced by decreasing the temperature, but this also decreases the reaction rates in the fuel cell.

Not only methanol crossover is a big disadvantage of the use of Nafion ${ }^{\circledR}$, but also Ruthenium $(\mathrm{Ru})$ cross-over has a large impact on the performance of DMFCs that utilize Ru at the anode. Ruthenium and Platinum (Pt) are catalysts at the anode which accelerate the half reaction given in Equation 1. After the diffusion of $\mathrm{Ru}$ through the membrane, it re-deposits at the cathode, decreasing the performance of the DMFC [8].

Another drawback of $\mathrm{Nafion}^{\circledR}$ is the high price because of the complicated and very toxic production method $[15,16]$. Therefore, there is a strong need to develop new membrane materials with low methanol cross-over and high proton conductivity.

\section{Scope and structure of this thesis}

High proton conductivity and low methanol cross-over are two desired properties of a good DMFC membrane. Although, Nafion, the current state of the art polymeric membrane, has high proton conductivity, it suffers from high methanol cross-over. This contributes to decreased overall cell efficiency and lifetime. The reaction of methanol at the cathode results in a loss of fuel and cathode voltage. In order to compete with lithium ion batteries for portable application market, these problems have to be solved. Therefore, there is a strong need to develop and modify new membrane materials for DMFC. To achieve this, in this thesis we attempt to answer the following important questions:

1. Can impregnation of the polyelectrolyte into microporous support decrease membrane swelling and methanol crossover producing a better DMFC membrane? (Chapters 2 and 3)

2. Does incorporation of conductive inorganic fillers into the polyelectrolyte polymer produce DMFC membranes with high proton conductivity and low methanol permeability? (Chapter 4)

3. Does micro-structuring of the polyelectrolyte membrane offer any advantage concerning better catalyst utilization in DMFC?

(Chapter 5) 
Finally, in Chapter 6, we reflect on the challenges faced in the project and give an outlook for future.directions for the development of DMFC membranes.

\section{References}

1. Kordesch, K. and Simader, G., Fuel Cells and Their Applications. 1996: VCH.

2. Vielstich, W., Lamm, A. and Gasteiger, H. A., Handbook of fuel cells: Volume 1 Fundamentals and survey of systems. 1 ed. 2003: John Wiley \& Sons Ltd.

3. Hogart, M. P. and Hards, G. A., Platinum Metals Rev., 1996. 150(40).

4. Scott, K., Shukla, A., Jackson, C. and Meuleman, W., A mixedreactants-solid-polymer-electrolyte direct methanol fuel cell. Journal of Power Sources, 2004. 126: p. 67-75.

5. Litster, S. and McLean, G., PEM fuel cell electrodes. Journal of Power Sources, 2004. 130: p. 61-76.

6. Witham, C. K., Chun, W., Valdez, T. I. and Narayanan, S. R., Performance of Direct Methanol Fuel Cells with Sputter-Deposited Anode Catalyst Layers. Electrochemical and Solid-State Letters, 2000. 3(11): p. 497-500.

7. Gulzow, E., Kaz, T., Reissner, R., Sander, H., Schilling, L. and Bradke, M. V., Study of membrane electrode assemblies for direct methanol fuel cells. Journal of Power Sources, 2002. 105: p. 261266.

8. Neburchilov, V., Martin, J., Wang, H. and Zhang, J., A review of polymer electrolyte membranes for direct methanol fuel cells. Journal of Power Sources, 2007. 169: p. 221-238.

9. Heitner-Wirguin, C., Recent advances in perfluorinated ionomer membranes: structure, properties and applications. Journal of Membrane Science, 1996. 120: p. 1-33. 
10. Vielstich, W., Lamm, A. and Gasteiger, H. A., Handbook of fuel cells: Volume 4 Fuel Cell Technology and Applications Part 2. 1 ed. 2003: John Wiley \& Sons Ltd.

11. Balster, J., Stamatialis, D. F. and Wessling, M., Electro-catalytic membrane reactors and the development of bipolar membrane technology. Chemical Engineering and Processing, 2003. 43(9): p. 11151127.

12. Alkorta, I. and Elguero, J., Theoretical models of directional proton molecular transport. Organic \& biomolecular chemistry, 2006.

13. Baxter, S. F., Bataliglia, V. S. and White, R. E., Journal Electrochemical Society, 1999. 437(146).

14. Vielstich, W., Lamm, A. and Gasteiger, H. A., Handbook of fuel cells: Volume 3 Fuel Cell Technology and Applications Part 1. 1 ed. 2003: John Wiley \& Sons Ltd.

15. Gil, M., Direct synthesis of sulfonated aromatic poly(ether ether ketone) proton exchange membranes for fuel cell applications. Journal of Membrane Science, 2004. 234: p. 75-81.

16. Chang, H., Protonconducting composite membranes derived from sulfonated hydrocarbon and inorganic materials. Journal of Power Sources, 2003(124): p. 18-25. 



\title{
Chapter 2
}

\section{Dimensionally stable Nafion-polyethylene composite \\ membranes for \\ direct methanol fuel cell applications}

M. Hakan Yildirim, Dimitris Stamatialis, Matthias Wessling

\begin{abstract}
Nafion ${ }^{\circledR}$ impregnated Solupor ${ }^{\circledR}$, microporous UHMWPE film, (N-PE), Nafion ${ }^{\circledR} 117$ (N117) and a membrane prepared using a DE2020 Nafion ${ }^{\circledR}$ dispersion (DE2020) were characterized with respect to their swelling degree, methanol cross-over, proton conductivity and DMFC performance at various methanol concentrations in order to understand the effect of impregnation of an ion-conductive polymer membrane to the fuel cell performance.

Introducing Nafion ${ }^{\circledR}$ into the pores of Solupor ${ }^{\circledR}$ causes reduction of both methanol cross-over and proton conductivity. Low proton conductivity of the N-PE membrane is compensated by its significantly low methanol crossover and this leads to better DMFC performance at 1 and $6 \mathrm{M}$ concentrations in comparison to $\mathrm{N} 117$ and DE2020 membranes. In addition to that, $\mathrm{N}-\mathrm{PE}$ composite membrane has high dimensional stability, low membrane thickness, good performance using less Nafion ${ }^{\circledR}$ ionomer, with reduced cost.

In addition to the real fuel cell measurements, characteristic $\beta$ values of the membranes were also calculated using both thickness dependent and independent methods. All characteristic values failed to predict the real fuel cell performance and should be used with caution.
\end{abstract}

Yildirim, M.H. et al. J. Membr. Sci., 2008. 321(2): p. 364. 


\section{Introduction}

Direct methanol fuel cells (DMFCs) can convert the chemical energy of a fuel directly into electrical energy. DMFCs can be used mainly as power sources to portable electronic devices like laptops, computers, cell phones and, to some extent, vehicular applications [1-5]. In order to compete with Li-ion batteries for portable applications higher power densities must be achieved. For that reason DMFCs should be operated at high methanol concentrations [6].

The proton exchange membrane (PEM) is the heart of DMFC. Currently, perfluorosulfonated ionomer (PFSI) membranes, like DuPont's Nafion ${ }^{\circledR}$ and Asahi Chemical's Aciplex ${ }^{\circledR}$, are used due to their excellent proton conductivity, mechanical strength and thermal and chemical stability [7-11]. However, these materials have also drawbacks like high methanol cross-over, especially at high methanol concentrations and, high cost $\left(\mathrm{US} \$ 700 / \mathrm{m}^{2}\right)$ due to the expensive fluorination step. To decrease the methanol cross over and cost, and at the same time increase the dimensional stability, PFSIs can be impregnated into a porous support. Polytetrafluoroethylene (PTFE) [12], Polyethylene-terephthalate (PETE) [13], Polycarbonate [14] and PE materials have been used as a support for the impregnation. Excessive swelling of the composite membrane can be suppressed by the porous support, while the methanol cross-over can also be minimized [6]. Yamaguchi et al. confirmed the advantages of impregnated membranes concerning low methanol crossover and high dimensional stability[15-18].

In this work, Nafion ${ }^{\circledR}$ impregnated Solupor ${ }^{\circledR}(\mathrm{N}-\mathrm{PE})$ composite membranes (kindly provided by DSM-Solutech, The Netherlands) are systematically characterized with respect to their swelling degree, proton conductivity, methanol permeability and DMFC performance at various methanol concentrations. For comparison, the performance of Nafion $₫ 117$ (N117) and DE2020 (membrane prepared using DE2020 Nafion ${ }^{\circledR}$ dispersion) membranes are investigated. Our research aims to get a better insight into effects of impregnation of conductive polymer into a non-conductive porous substrate and evaluate the performance of the membranes with respect to the above mentioned characterization methods.

\section{Experimental}

\subsection{Materials}

N-PE membranes $(26 \mu \mathrm{m})$ were kindly provided by DSM-Solutech (The Netherlands) $[19,20]$. N117 membranes $(185 \mu \mathrm{m}$ and 1100 equivalent weight 
(EW)) and DMSO were purchased from Aldrich (Germany). DE2020 Nafion ${ }^{\circledR}$ dispersion (20wt. \% Nafion ${ }^{\circledR}+80$ wt. \% water and VOCs, 1000EW), which is also the material impregnated into PE by DSM-Solutech, was purchased from DuPont Fluoroproducts (U.S.A.). E-TEK electrodes were purchased from E-TEK DeNora (U.S.A.).

\subsection{Preparation of DE2020 membranes}

A certain amount of DMSO was added to the DE2020 dispersion to decrease the evaporation rate of the solvent at the drying step and get a defect free membrane. The added amount of DMSO was the same as the dry weight of Nafion ${ }^{\circledR}$ in the dispersion. The dispersion was cast on Teflon plate with a casting knife and then placed in a fumehood for 18 hours. After that the membrane was annealed at $150^{\circ} \mathrm{C}$ for 1 hour and was peeled off from the teflon plate. The final dry thickness of the membrane was $80 \mu \mathrm{m}$.

\subsection{Membrane characterization}

\section{Scanning electron microscopy (SEM)}

Membranes were visualized by a scanning electron microscope (Jeol JSM $5600 \mathrm{LV})$. The membrane samples were sputtered with a thin layer of gold (30 nm) using a Balzers Union SCD 040 sputtering device prior to the SEM observation.

\section{Porosity of the composite membrane}

The porosity of the N-PE membrane, $\varphi_{\mathrm{p}}(\%)$, was estimated using the following equation (Eq. 1) [22], where $w_{f p}^{d}$ weight of the dry Nafion $\AA, w_{s u b}^{d}$ weight of the dry poly(ethylene) substrate, $\rho_{f p}$ the density of Nafion ${ }^{\circledR}, \rho_{P E}$ the density of $\mathrm{PE}$, and $V_{m e m}^{d}$ is the dry membrane volume estimated from the geometric membrane area $(A)$ and thickness $(I)$.

$$
\varphi_{P}=\left\{1-\frac{\frac{w_{f p}^{d}}{\rho_{f p}}+\frac{w_{s u b}^{d}}{\rho_{P E}}}{V_{m e m}^{d}}\right\} .100
$$


Swelling degree (SD)

Membranes were dried in the vacuum oven at $30^{\circ} \mathrm{C}$ for 1 day and then immersed in ultra pure water or methanol solutions of various concentrations. The weight, thickness and the area of the wet (Value ${ }_{\text {wet }}$ ) and the dry (Value $\left._{\text {dry }}\right)$ samples were measured. The SD of the membrane was calculated using:

$$
S D(\%)=\left(\frac{\text { Value }_{w e t}-\text { Value }_{d r y}}{\text { Value }_{d r y}}\right) \cdot 100
$$

\section{Methanol permeability}

A two compartment diffusion cell was used for the methanol permeability experiments. Prior to all experiments, the membrane was equilibrated in ultra pure water for $24 \mathrm{~h}$. Then it was clamped between the two cell compartments. One compartment was filled with ultra pure water and the other with methanol solution. Both sides were stirred and the temperature was controlled at $25^{\circ} \mathrm{C}$. Samples were taken from both compartments at various times and analyzed by GC (Shimadzu 2010, with a Hayesep Q 80/100 column). The methanol permeability, $\mathrm{P}\left[\mathrm{cm}^{2} / \mathrm{s}\right]$, and the diffusivity, $\mathrm{D}\left[\mathrm{cm}^{2} / \mathrm{s}\right]$, were calculated using the equations:

$$
\begin{gathered}
\frac{C_{B}(t) \cdot V_{B} \cdot l}{\left(C_{A}(t)-C_{B}(t)\right) \cdot A}=P \cdot\left(t-t_{0}\right), \\
t_{0}=\frac{l^{2}}{6 D}
\end{gathered}
$$

where $C_{B}[\mathrm{~mol} / \mathrm{L}]$ and $\mathrm{C}_{\mathrm{A}}[\mathrm{mol} / \mathrm{L}]$ are concentrations in the water and methanol compartments respectively, $V_{B}[\mathrm{~L}]$ is the volume of the water compartment, $l[\mathrm{~m}]$ is the thickness of the wet membrane, A $\left[\mathrm{m}^{2}\right]$ is the surface area of the membrane, $t[s]$ is the time and $t_{0}$ is the time lag, for the permeation of methanol through the membrane. 


\section{Proton conductivity}

The proton conductivity measurements were performed by impedance spectroscopy in a home-made cell. Prior to all experiments, the membrane was equilibrated in ultra pure water or various methanol solutions from $1 \mathrm{M}$ to $10 \mathrm{M}$ for $24 \mathrm{~h}$. The cell has Teflon interior with two circular gold electrodes, with surface area of $0.28 \mathrm{~cm}^{2}$. Both electrodes are connected with two wires, one for carrying the current and one for acting as potential probe. The cell was connected to a frequency response analyzer (Solatron 1255). A membrane sample was sandwiched between the gold electrodes and the resistance through the plane was measured. The impedance spectrum was measured in the frequency range $100 \mathrm{~Hz}-0.2 \mathrm{MHz}$ with a potential of $0.01 \mathrm{~V}$ at $25^{\circ} \mathrm{C}$ and $100 \%$ relative humidity. The resistance value associated with the membrane conductivity was determined from the high frequency intercept of the impedance with the real axis. The conductivity was calculated using the equation:

$$
\sigma=\frac{l}{R \cdot A_{e}}
$$

where, $\sigma$ is the proton conductivity of the membrane $[\mathrm{S} / \mathrm{cm}], \mathrm{R}$ is the membrane resistance $[\Omega]$ and $A_{e}$ is the surface area of the electrodes $\left[\mathrm{cm}^{2}\right]$.

\subsection{Fabrication of membrane-electrode assemblies}

E-TEK commercial electrodes were used to fabricate the membraneelectrode assemblies (MEAs). Both anode and cathode contain $5 \mathrm{mg} / \mathrm{cm}^{2} \mathrm{Pt}$ $\mathrm{Ru}$ and Pt, respectively. The geometric area of each electrode was $6.25 \mathrm{~cm}^{2}$. The MEAs were prepared by hot pressing of the anode and cathode on both sides of the membrane at 2,10 and 29 bar for $3-5$ minutes at $120-125^{\circ} \mathrm{C}$.

\subsection{Single cell DMFC performance}

The performance of the MEAs was evaluated using a DMFC set-up constructed by the Energy Research Centre (ECN, The Netherlands). The MEA was clamped between two graphite blocks. A serpentine flow pattern is etched in each of the graphite blocks to provide fuel to the MEA. Both graphite blocks were connected with electrical wires to an adjustable elec- 
trical load. The cell was thermostated with a heating bath and the temperature of the cell was measured with a thermocouple. The methanol solution was fed to the anode at flow rates of $20 \mathrm{ml} / \mathrm{min}$ and dry oxygen was fed to the cathode at flow rates of $75 \mathrm{ml} / \mathrm{min}$ and back pressure of 2 bar. The temperature of the cell was kept at $80^{\circ} \mathrm{C}$. Polarization curves were measured by applying different currents and measuring the correspondent cell voltages. The current was increased step by step till the cell voltage became zero. The equilibration time between the measured points was at least 30 seconds and the difference between the voltages in the last two seconds of each point was less than $1 \mathrm{mV}$.

\section{Results and discussion}

\subsection{SEM study of N-PE composite membrane}

Figure 1 shows SEM image of the cross-section of N-PE composite membrane. It seems that the N-PE membrane consists of an impregnated middle layer of $13-15 \mu \mathrm{m}$ and two layers of pure conductive polymer at the top and bottom $(\sim 5 \mu \mathrm{m})$. The porosity of the pure Solupor ${ }^{\circledR}$ film is $85 \%$ according to the manufacturer. The porosity of the middle layer of the N-PE composite membrane is obtained by subtracting, weight and volume of the top and bottom Nafion ${ }^{\circledR}$ layer using eq. 1 and it is $27 \%$. This indicates that the impregnation is rather incomplete and air might be trapped in the non-filled pores of the substrate.

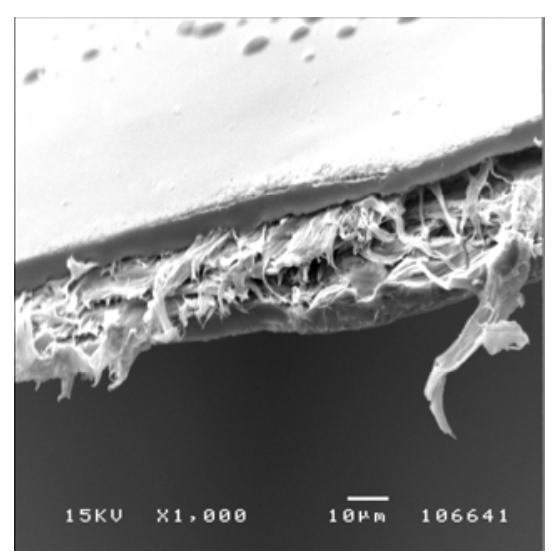

Figure 1. SEM images of cross-section of N-PE composite membrane. 
3.2. Swelling experiments
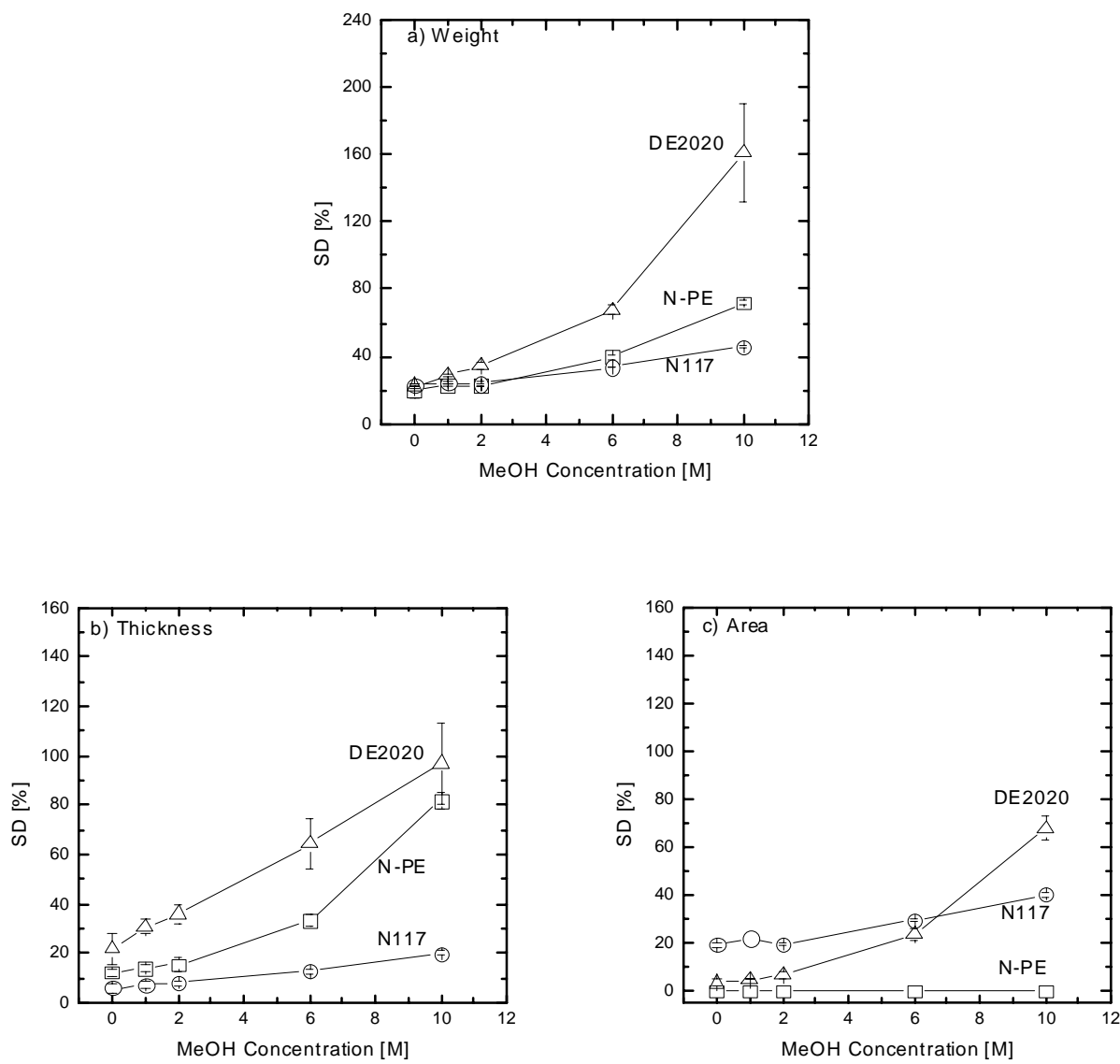

Figure 2. Swelling degrees of N-PE, N117 and DE2020 membranes, (a) by weight, (b) in the thickness and (c) in the area direction.

Figure 2 shows the results of the swelling experiments of N-PE, N117 and DE2020 membranes. For all membranes, swelling by weight increases with methanol concentration (Fig. 2a). DE2020 membrane swells more than N117 and N-PE, probably due to its higher ion-exchange capacity. The swelling of the N-PE membrane in the thickness direction is significantly higher than the N117 membrane especially at high methanol concentrations 
(Fig. 2b). This might be due to the swelling of the top and bottom Nafion ${ }^{\circledR}$ layers (see Fig. 1). However, swelling of the N-PE membrane is almost negligible in the area direction (Fig. 2c). Probably, the Solupor ${ }^{\circledR}$ substrate suppresses the swelling of the composite membrane. This is expected to be very advantageous to the dimensional stability of the MEAs. In contrast the swelling in the area direction of the N117 and DE2020 membranes increases at high methanol concentration. These findings are consistent with the work of Yamaguchi et al. [6] and Liu et al [12] with other types of composite membrane swelling data.

\subsection{Methanol permeability}

Figure 3 shows the methanol permeabilities of the membranes as a function of methanol concentration. Table 1 presents the permeability and diffusivity results for the three membranes at $1 \mathrm{M}$ (the diffusivity was calculated from the lag time (see eq. 4)). For both DE2020 and N117 membranes, methanol permeability increases with methanol concentration. DE2020 has higher methanol permeability than the $\mathrm{N} 117$ membrane in the whole concentration range, probably due to its higher ion-exchange capacity, which leads to high swelling. For N-PE membrane the methanol permeability is more or less constant till $6 \mathrm{M} \mathrm{MeOH}$, but increases significantly at $10 \mathrm{M}$. Still, the methanol permeability of N-PE is much lower than that of N117 and DE2020 membranes (Fig. 3). It seems that the low methanol cross-over of the N-PE is due to the low methanol diffusivity through the membrane and especially through the middle layer.

To get a better insight into this, we made a calculation using the resistance in series model. The N-PE membrane consists of three layers, two layers of DE2020 (top and bottom) and one middle layer of impregnated Solupor ${ }^{\circledR}$ (see Fig.1). Using the resistance model and assuming the permeability of the top/bottom layer is that of pure DE2020, one can calculate the permeability of the middle layer at $1 \mathrm{M}$ using the equation:

$$
\frac{l_{N-P E}}{P_{N-P E}}=2 \cdot \frac{l_{D E 2020}}{P_{D E 2020}}+\frac{l_{\text {middle layer }}}{P_{\text {middle layer }}}
$$

where, $l_{N-P E}, P_{N-P E}, l_{D E 2020}, P_{D E 2020}, l_{\text {middle layer }}$ and $P_{\text {middle layer }}$ are the thicknesses and permeabilities of the composite membrane, top/bottom layer of the 
composite membrane and the middle layer of the composite membrane, respectively. Table 1 presents the results where one can see that the methanol permeability of the middle layer seems to determine the overall methanol permeability. The low methanol permeability at the middle layer is probably due to the presence of the non-conductive hydrophobic Solupor ${ }^{\circledR}$ and the presence of the unfilled pores of PE (as indicated by the porosity calculation) contributes to this, too.

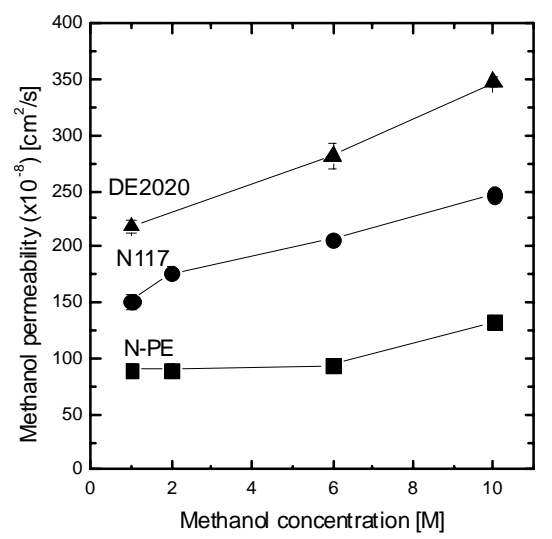

Figure 3. Methanol permeabilities of N-PE, DE2020 and N117 membranes as a function of methanol concentration.

Table 1. Methanol permeabilities (in $1 \mathrm{M} \mathrm{MeOH}$ ), diffusivities (in $1 \mathrm{M} \mathrm{MeOH}$ ) and proton conductivities (in ultra pure water (upw)) of the membranes.

\begin{tabular}{|c|c|c|c|}
\hline Membrane & $\begin{array}{l}\text { Permeability } \\
\left(x 10^{-8}\right)\left[\mathrm{cm}^{2} / \mathrm{s}\right] \\
\text { (in } 1 \mathrm{M} \mathrm{MeOH)}\end{array}$ & $\begin{array}{c}\text { Diffusivity } \\
\left(x 10^{-8}\right)\left[\mathrm{cm}^{2} / \mathrm{s}\right] \\
(\text { in } 1 M \mathrm{MeOH})\end{array}$ & $\begin{array}{c}\text { Conductivity } \\
\left(x 10^{-2}\right)[\mathrm{S} / \mathrm{cm}] \\
\text { (in upw) }\end{array}$ \\
\hline DE2020 & 220 & 16 & 3.5 \\
\hline N117 & 150 & 9 & 6.3 \\
\hline N-PE & 95 & 0.8 & 0.6 \\
\hline N-PE middle layer* & 66 & 0.5 & 0.4 \\
\hline
\end{tabular}

*Estimated by resistance in series model. 


\subsection{Proton conductivity}

Figure $4 \mathrm{a}$ presents the proton conductivities of N117, N-PE and DE2020 membranes as a function of methanol concentration. The proton conductivity of DE2020 membrane is low in water and then increases reaching a plateau at $\sim 7.5 \times 10^{-2} \mathrm{~S} / \mathrm{cm}$. The proton conductivity of the $\mathrm{N} 117$ membrane is also high and does not change much up to $6 \mathrm{M}$ methanol concentration, but decreases slightly at $10 \mathrm{M}$. The conductivity of the N-PE membrane increases with increasing methanol concentration over the measured concentration range. However, it is much lower than the N117 and DE2020 membranes. Application of resistance in series model indicates that the conductivity of the middle layer ( $\mathrm{PE}+\mathrm{DE} 2020)$ determines again the overall N-PE conductivity (see example for the conductivity in ultra pure water in Fig. $4 \mathrm{~b}$ and Table 1).
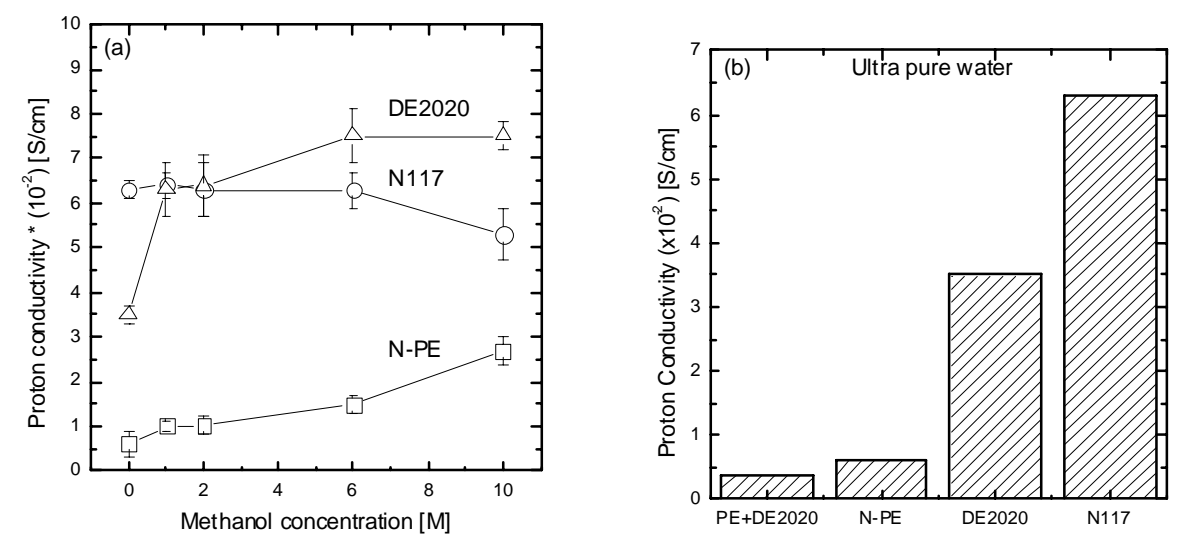

Figure 4. (a) Proton conductivities of N-PE, DE2020 and N117 as a function of methanol concentration. (b) The proton conductivity of the various membranes in ultra pure water (see details in text and Table 1).

\subsection{Single cell performance prediction}

As we have seen in previous paragraphs, the impregnation of Nafion ${ }^{\circledR}$ into $\mathrm{PE}$ support causes a decrease in both methanol cross-over and proton conductivity. High proton conductivity and low methanol cross-over is desired to obtain high fuel cell performance. In literature, especially when fuel cell 
data are not available, prediction of the fuel cell performance is often made [21-23] using the so-called characteristic number of a specific membrane, $\beta_{1}$; the ratio of the proton conductivity of the membrane over to its methanol permeability:

$$
\beta_{1}=\frac{\sigma}{P}
$$

It is important to keep in mind that this characteristic number is independent of membrane thickness.

In order to compare the performances of membranes of different thicknesses, it might be better to estimate characteristic numbers dependent on membrane thickness, such as those in eq. 8 and 9 .

$$
\begin{aligned}
& \beta_{2}=\frac{\text { Areal resistance }}{\text { Flux }_{\mathrm{MeOH}}} \\
& \beta_{3}=\frac{1}{\text { Areal resistance }} \\
& \text { Flux } \\
& \mathrm{MeOH}
\end{aligned}
$$

Figure 5 presents the estimated $\beta_{1}, \beta_{2}$ and $\beta_{3}$ values for all membranes of this study at various methanol concentrations. N117 membrane has the highest $\beta_{1}$ value at $1 \mathrm{M}$ and N-PE has the lowest (Fig. 5a). The values of both N117 and DE2020 membranes decrease at higher methanol concentration whereas the $\beta_{1}$ of N-PE membrane increases due to its low methanol permeability and increasing conductivity at higher methanol concentration.

For both $\beta_{2}$ and $\beta_{3}, \mathrm{~N} 117$ membrane has the highest value at $1 \mathrm{M}$. Interestingly, there is no difference between the trend of $\beta_{2}$ and $\beta_{3}$ of all membranes at high concentrations.

As a conclusion, thickness dependent $\left(\beta_{2}\right.$ and $\left.\beta_{3}\right)$ and independent $\left(\beta_{1}\right)$ methods predict that the N117 membrane will perform better than N-PE and DE2020 membranes at 1M, but the differences will become smaller at 
high methanol concentration. In fact, one should expect more or less the same performance to all membranes at 6 and 10M. In the next chapter real fuel cell performances of these membranes will be investigated and compared to these predictions.
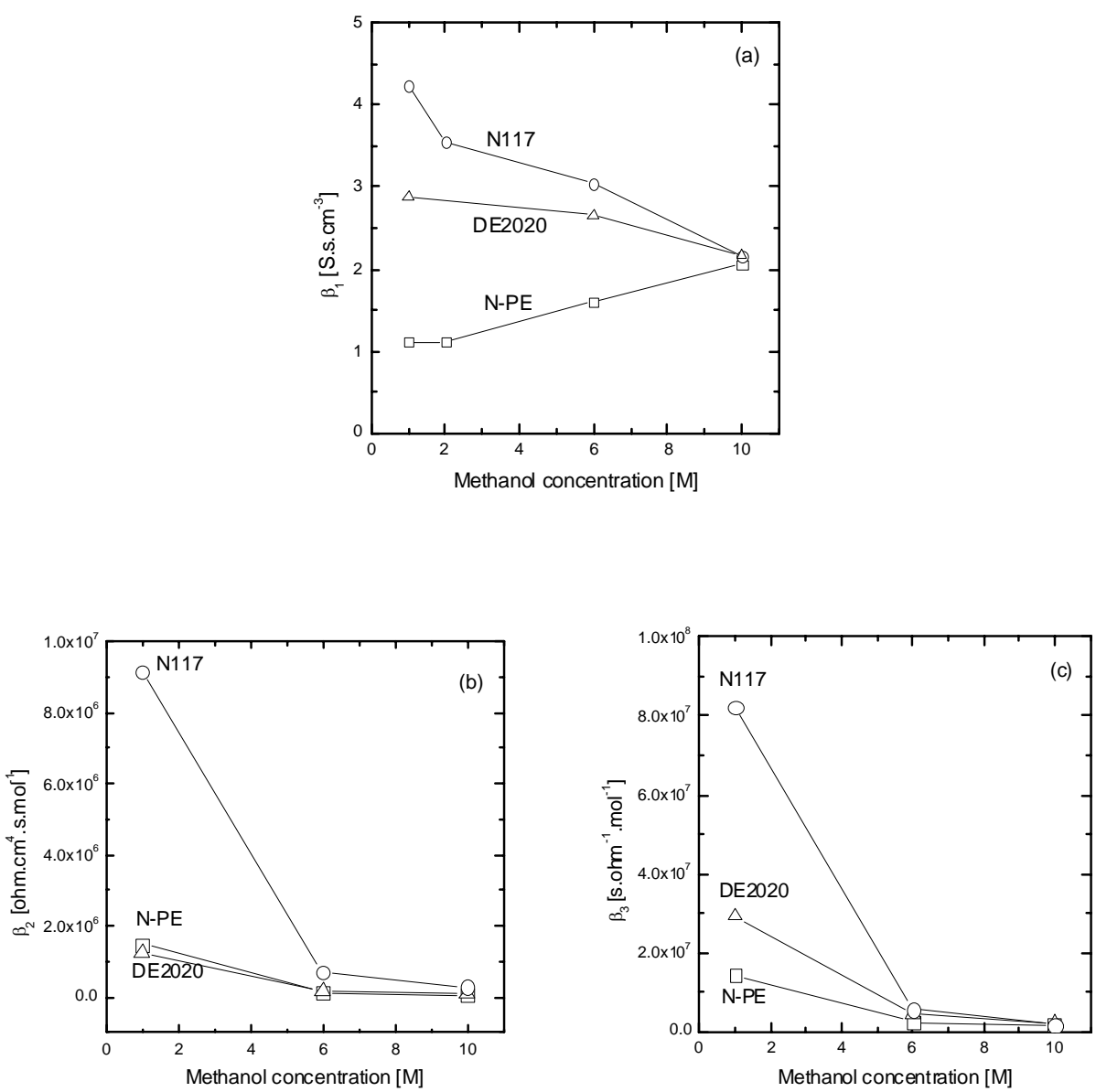

Figure 5. $\beta_{1}, \beta_{2}$ and $\beta_{3}$ characteristic values as a function of methanol concentration.

\subsection{Single cell performance}

As mentioned in the experimental part, MEAs were prepared by hot pressing two E-TEK commercial electrodes on both sides of the N-PE, N117 and DE2020 membranes at various pressures. Approximately 70 polarization 
curves were measured for each MEA. Figure 6 presents typical results of maximum power density of each polarization curve as a function of time for N117 membrane at various pressures. It seems that in the beginning of the experiment maximum power densities increase due to the activation of all catalyst particles and also due to wetting of the membrane. After all catalyst particles are accessible and the membrane is wetted, the maximum power density reaches a plateau. (All polarization curves of this study were taken when the max power density value reached the plateau).
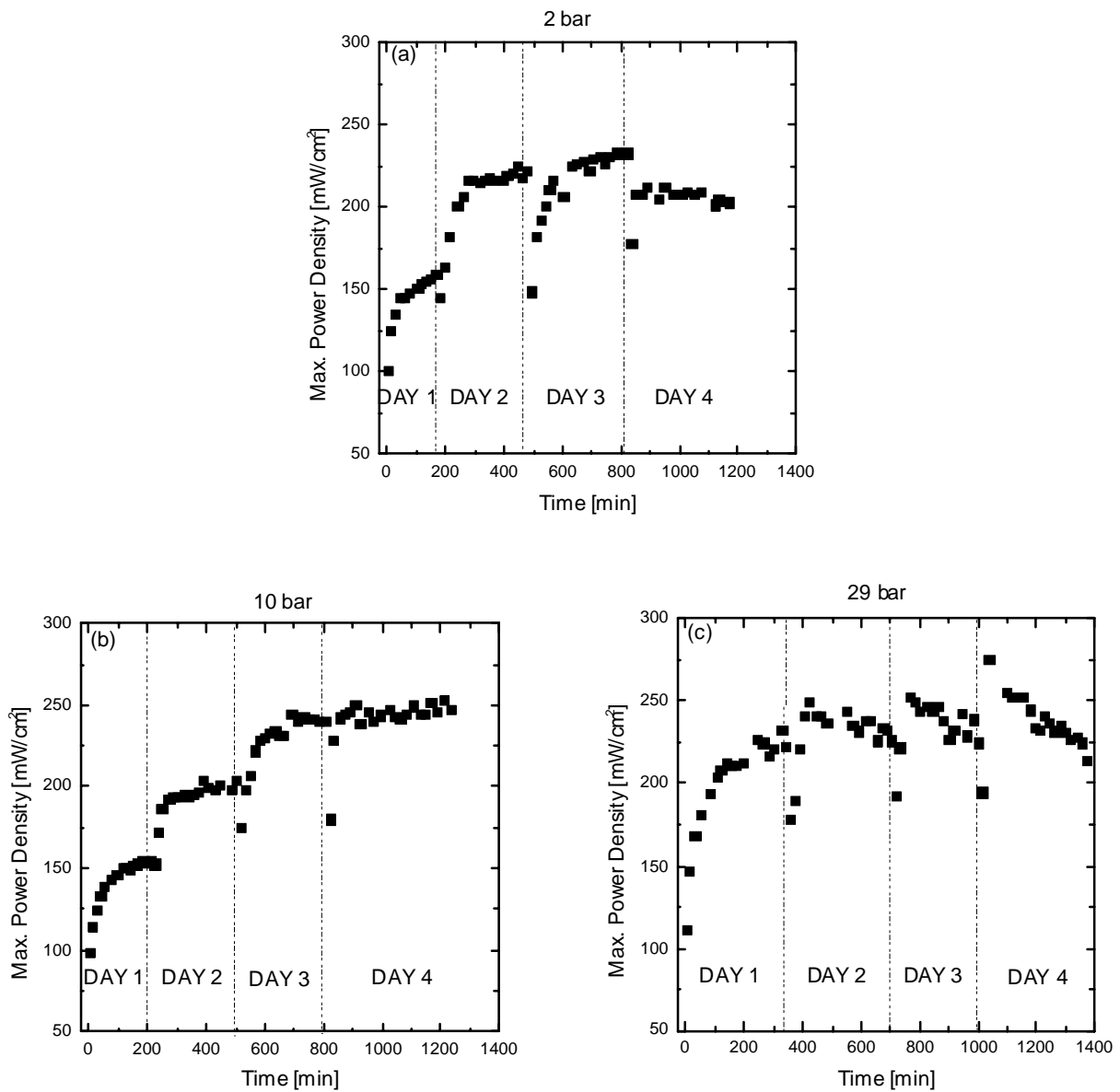

Figure 6. Maximum power density values of N117 membrane (at $1 \mathrm{M}$ methanol concentration) as a function of measurement time for various MEA preparation pressures, (a) 2bar, (b) 10bar and (c) 29 bar. 
When the electrodes are hot pressed at 2bar, the MEA produces around $220 \mathrm{~mW} / \mathrm{cm}^{2}$ (Fig. 6a). In the case of 10 and 29 bar (Fig. 6b, c), MEA performs slightly better and the maximum value is about $250 \mathrm{~mW} / \mathrm{cm}^{2}$. However, it seems that the maximum power density of MEA prepared at 29 bar pressure is rather unstable in time. In the beginning of the day it shows an increase and then starts to decrease till the end of the measurement time. MEA's prepared under 10 bar pressure perform slightly better and are also stable at least after the $3^{\text {rd }}$ day. Based on these results, we used 10 bar to prepare MEAs with N117, N-PE and DE2020 membranes, reported in the following sections.

Figure 7 shows the polarization curves of $\mathrm{N} 117$ membrane on day 1 and day 4 for various MEA preparation pressures. The performances of each MEA on day 4 are significantly improved in comparison to day 1 due to the conditioning effects of all measurements on the membrane.

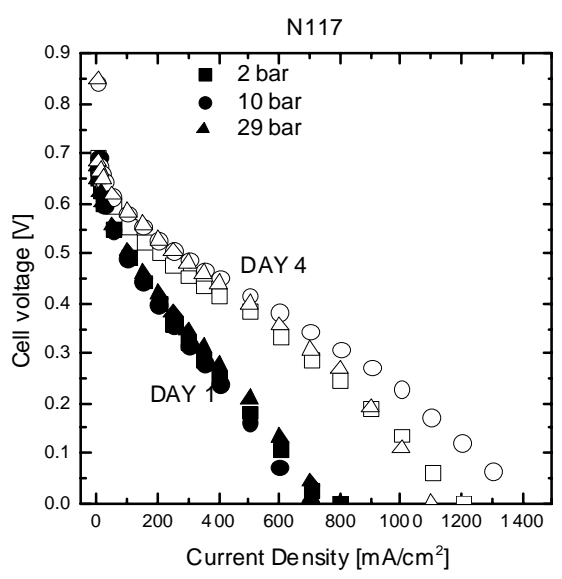

Figure 7. Day 1 (filled symbols) and day 4 (open symbols) performance of N117 membrane for various MEA preparation pressures (1M methanol concentration).

Figure 8 shows the maximum power densities of various membranes as a function of time. The concentration of methanol at the anode side was 1M. Each symbol in the graph corresponds to a different MEA. For all membranes, the maximum power density increases in time and reaches a plateau. The average power densities of N-PE, N117 and DE2020 membranes 
are $280 \mathrm{~mW} / \mathrm{cm}^{2}$ (Fig. 8a), $225 \mathrm{~mW} / \mathrm{cm}^{2}$ (Fig. 8 b) and $250 \mathrm{~mW} / \mathrm{cm}^{2}$ (Fig. 8c), respectively.
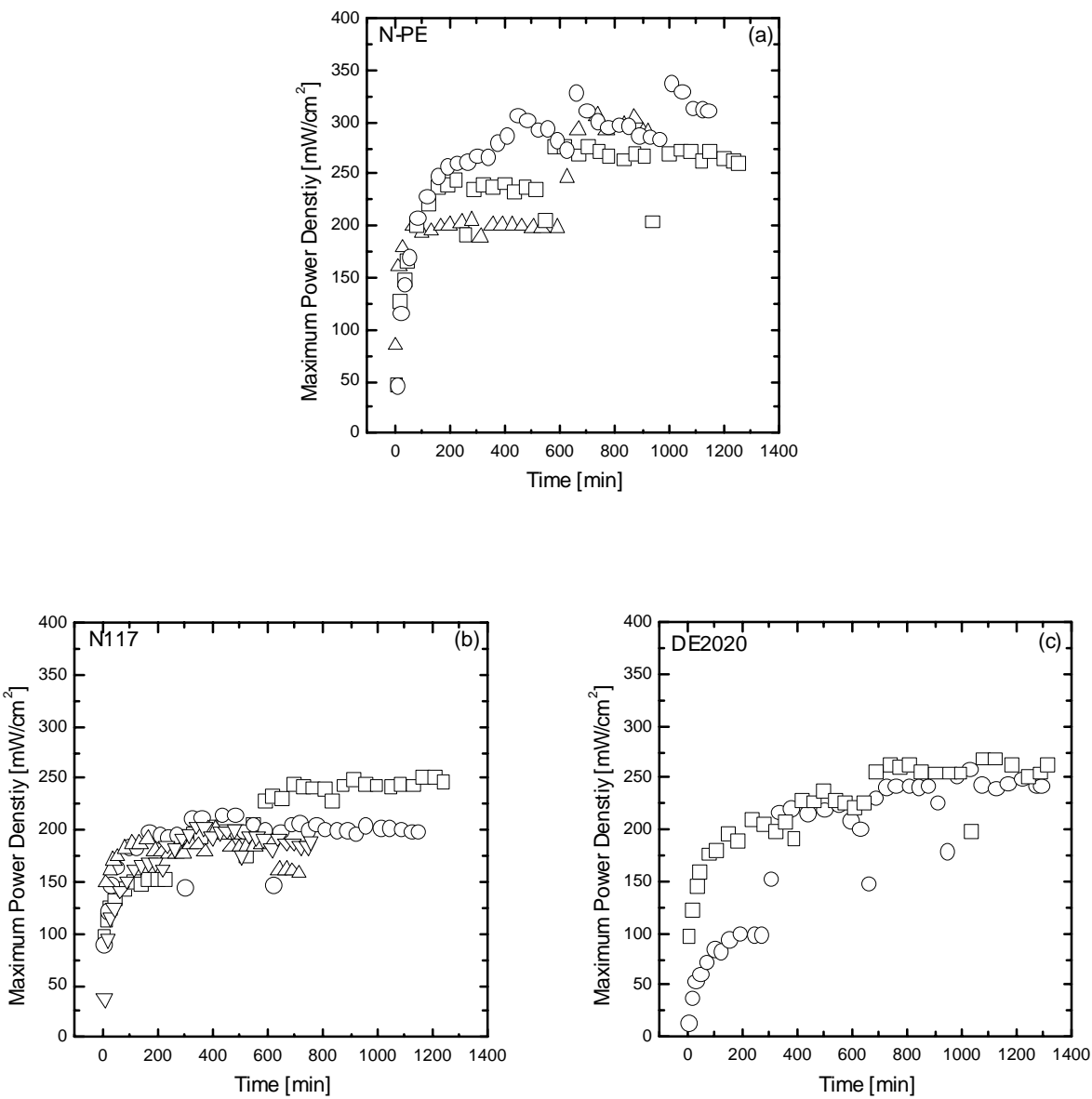

Figure 8. Maximum power densities of N-PE, N117 and DE2020 membranes (at 1M) as a function of time. The different symbols in each case correspond to different MEA.

Figure 9 presents polarization and power density curves corresponding to the plateau values of Fig. 8. N-PE is the thinnest membrane of all three and has the lowest open cell voltage $(\mathrm{OCV})(\sim 0.65 \mathrm{~V})$. When the membrane thickness is small the pathway for methanol cross-over gets short. Therefore the 
OCV value of the membrane gets lower. In fact the OCV values correspond to the membrane thickness and follow the order of N117 $(185 \mu \mathrm{m})>\mathrm{DE} 2020$ $(80 \mu \mathrm{m})>\mathrm{N}-\mathrm{PE}(26 \mu \mathrm{m})$ (see Fig. 9a). Chen et al [24] also reported lower OCV for their composite membrane in comparison to the thicker Nafion ${ }^{\circledR}$ membrane. Small membrane thickness also leads to a shorter pathway for the protons to pass through the membrane. High proton flux compensates the high methanol flux of the composite membrane and leads to a better overall performance of the composite membrane than N117 and DE2020 membranes.
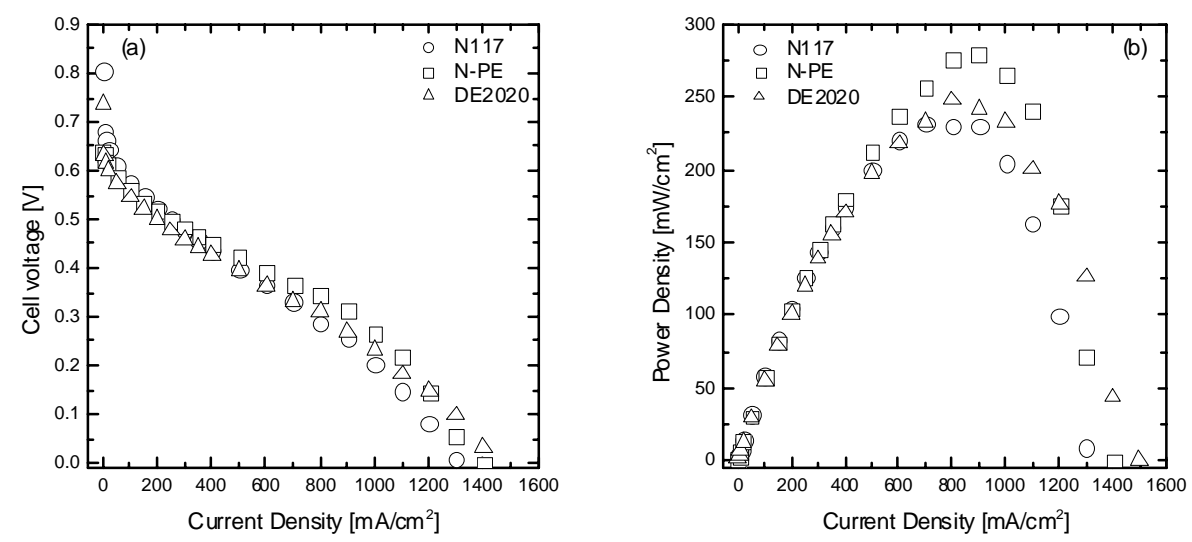

Figure 9. Polarization and power density curves of N-PE, N117 and DE2020 membranes (at $1 \mathrm{M})$.

In the literature one can find several papers reporting the performance of

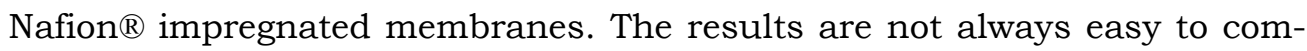
pare with our own, since the experimental conditions differ. For example, Chen et al [24], Lin et al [25] and Huang et al [26] also measured the performances of their Nafion ${ }^{\circledR}$ impregnated PTFE (N-PTFE) composite membranes and N112 or N117 membranes. Measurements were performed with $2 \mathrm{M}$ and $5 \mathrm{M}$ methanol solutions which were fed to the anode at a flow rate of $5 \mathrm{ml} / \mathrm{min}$. Dry oxygen was fed to the cathode at a flow rate of $150 \mathrm{ml} / \mathrm{min}$. The temperature of the cell was $70^{\circ} \mathrm{C}$ for Lin et al [25] and Huang et al [26] and $80^{\circ} \mathrm{C}$ for Chen et al [24]. Anode and cathode contained $4 \mathrm{mg} / \mathrm{cm}^{2} \mathrm{Pt}-\mathrm{Ru}$ and $2 \mathrm{mg} / \mathrm{cm}^{2} \mathrm{Pt}$, respectively. At $2 \mathrm{M}$ methanol concentration, the N-PTFE 
composite membrane reached approximately $90 \mathrm{~mW} / \mathrm{cm}^{2}$ and the $\mathrm{N} 117$ and $\mathrm{N} 112$ reached almost $55 \mathrm{~mW} / \mathrm{cm}^{2}$. The lower power densities reported in their studies might be due to the low catalyst loading in comparison to our study.
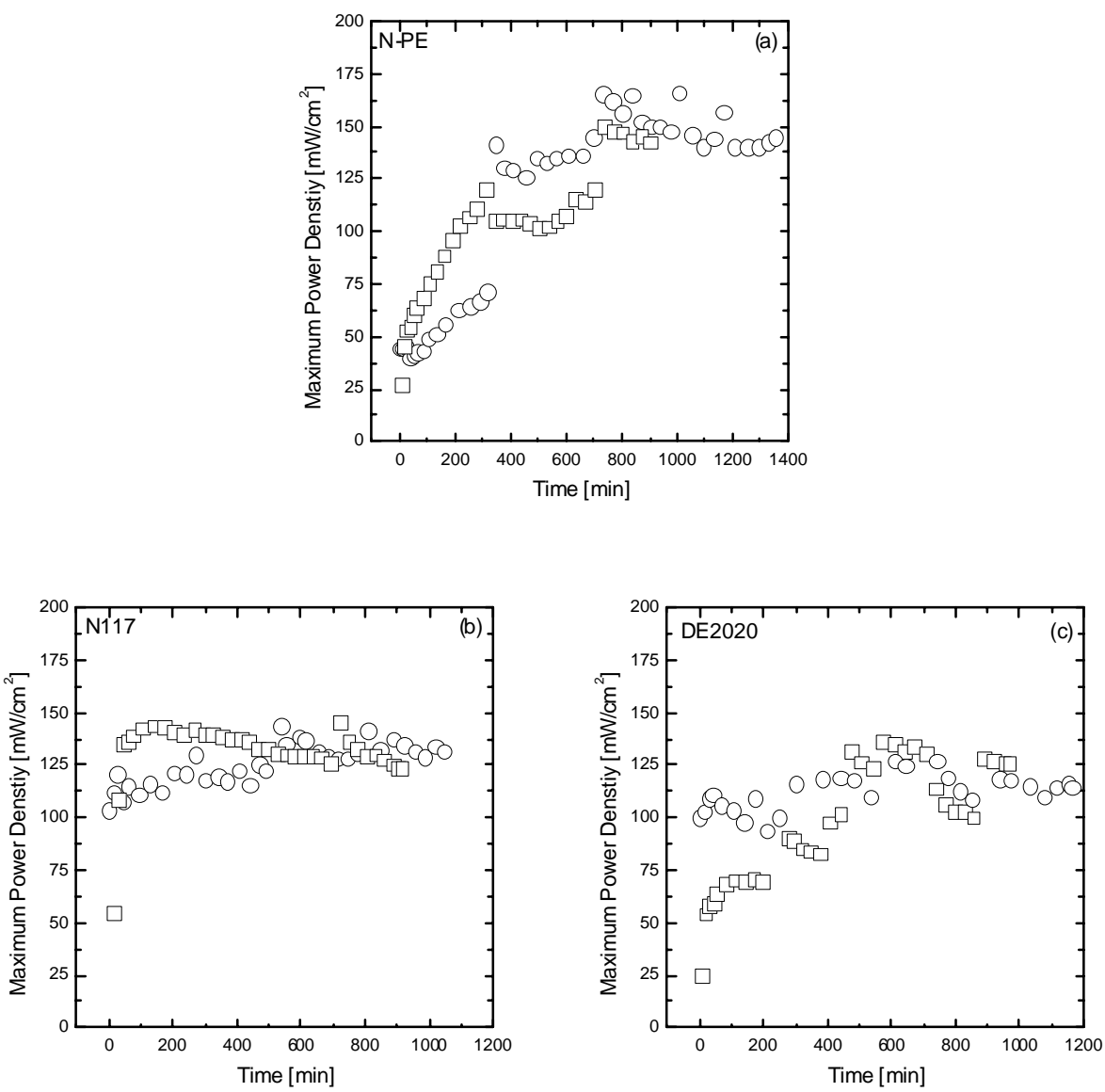

Figure 10. Maximum power densities of N-PE, N117 and DE2020 membranes (at 6M) as a function of measurement time. The different symbols in each case correspond to different MEA.

Figure 10 shows the maximum power densities of various membranes at $6 \mathrm{M}$ methanol concentration as a function of measurement time. Each symbol corresponds to a different MEA. Average maximum power densities of N- 
PE (Fig. 10a), N117 (Fig. 10b) and DE2020 (Fig. 10c) membranes are $145 \mathrm{~mW} / \mathrm{cm}^{2}, 130 \mathrm{~mW} / \mathrm{cm}^{2}$ and $115 \mathrm{~mW} / \mathrm{cm}^{2}$, respectively.

Figure 11 presents polarization and power density curves corresponding to the plateau values of Fig. 10. The OCV of N117 is higher than N-PE and DE2020 due to its higher thickness. Although DE2020 is thicker than N$\mathrm{PE}$, they have similar OCV values, probably due to the high methanol crossover through the DE2020 membrane. N-PE performs better than N117 and DE2020 when the current density is above $400 \mathrm{~mA} / \mathrm{cm}^{2}$. N117 and DE2020 show mass transport limitations at around $800 \mathrm{~mA} / \mathrm{cm}^{2}$, whereas N-PE reaches up to $1200 \mathrm{~mA} / \mathrm{cm}^{2}$ (Fig. 11a). Lin et al [25] and Huang et al [26] have also measured the performances of their Nafion impregnated PTFE membrane and N112 membrane at 5M methanol solution. Both N-PTFE and N112 membranes showed similar performances, approximately $30 \mathrm{~mW} / \mathrm{cm}^{2}$, much lower than the measurements at $2 \mathrm{M}$. The same behavior is observed in our measurements as well. The performance at $6 \mathrm{M}$ of all three membranes is lower than in $1 \mathrm{M}$. However, the N-PE shows better performance than both N117 and DE2020. This may be due to the low methanol cross-over and to the dimensional stability of N-PE (see Fig. 2).
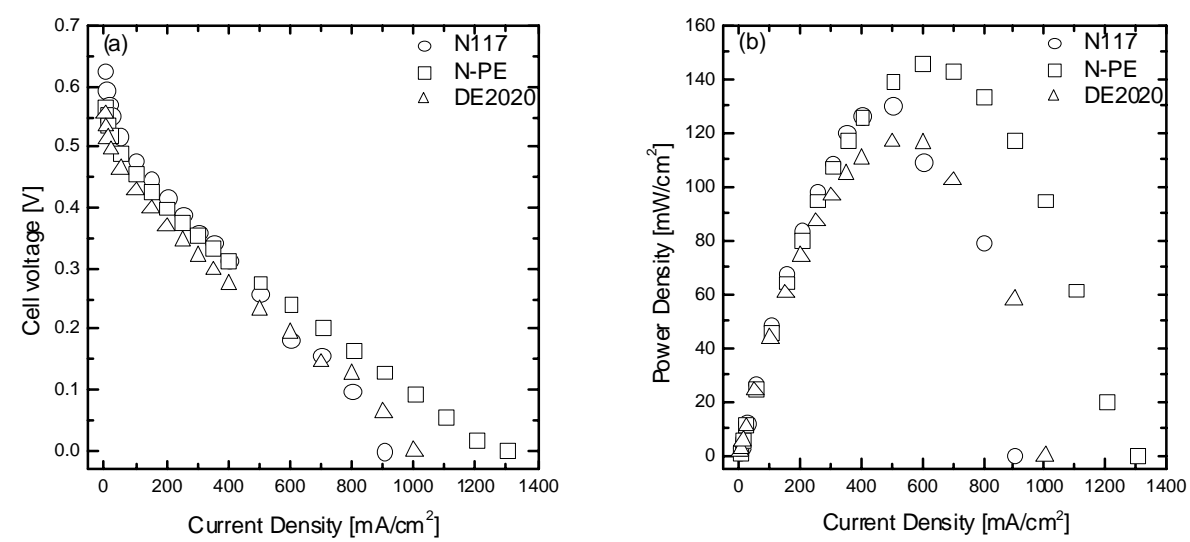

Figure 11. Polarization and power density curves of N-PE, N117 and DE2020 membranes (at $6 \mathrm{M})$.

In section 3.5, characteristic values of the investigated membranes were calculated using thickness dependent $\left(\beta_{2}\right.$ and $\left.\beta_{3}\right)$ and independent $\left(\beta_{1}\right)$ methods to predict the fuel cell performance. Both methods predicted that the N117 membrane will perform better than N-PE and DE2020 membranes 
at $1 \mathrm{M}$, in contrast to the actual fuel cell results. In fact, N-PE membrane performed better than both $\mathrm{N} 117$ and DE2020 membranes. According to $\beta_{1}$, the performance of $\mathrm{N} 117$ and DE2020 should become worse and of N-PE better at high methanol concentration. $\beta_{2}$ and $\beta_{3}$ predict that the performance of all membranes would become worse at high methanol concentration and all membranes would have similar performances at high concentrations. The actual fuel cell data show indeed a decrease in the performance for all membranes at $6 \mathrm{M}$. The order in performance of the membranes as predicted by $\beta_{1}$ (N117 should be the best) and $\beta_{2}, \beta_{3}$ (all should be the same) does not correspond to the fuel cell results. In conclusion, our study shows clearly that one should be very critical when using characteristic values to predict the fuel cell performance. It seems that all characteristic values have very little predictive value. One should perform real fuel cell experiments in order to select the suitable membrane for DMFC application.

\section{Conclusions}

N-PE, N117 and DE2020 membranes were characterized with respect to their swelling degree, methanol cross-over, proton conductivity and DMFC performance in order to understand the effect of impregnation of a conductive polymer into a porous non-conductive substrate. The methanol permeability and the proton conductivity of the N-PE composite membrane are lower than N117 and DE2020 membranes. N-PE membrane consists of an impregnated middle layer and two layers of pure conductive polymer at the top and bottom. The middle layer is the transport controlling layer. Low proton conductivity of the N-PE membrane is compensated by its significantly low methanol cross-over and this leads to a better DMFC performance at 1 and $6 \mathrm{M}$ concentrations in comparison to N117 and DE2020 membranes. In addition to these, N-PE composite membrane has the advantages of high dimensional stability, low membrane thickness, good performance with less amount of Nafion ${ }^{\circledR}$ ionomer. All characteristic values $\beta_{1}, \beta_{2}$ and $\beta_{3}$ calculated in this study failed to predict the order of performances of the membranes.

\section{Acknowledgements}

This research was financially supported by the Dutch Technology Foundation STW (Project no: 5713). The authors wish to thank: 
- Dr. Gijs Calis and Ir. Harold Smelt (DSM Solutech, The Netherlands) for supplying the N-PE membranes and discussions.

- Dr. Bernard Boukamp (University of Twente) for building the conductivity set-up.

- Dr. Bernd Bauer (FumaTech GmbH, Germany) and Dr. Ronald Mallant (ECN, The Netherlands) for discussions and suggestions concerning this work.

\section{References}

1. S. Surampudi, Narayanan, S. R., Vamos, E., Frank, H., Halpert, G., LaConti, A., Kosek, J., Prakash, G. K. Surya, and Olah, G. A., Advances in direct oxidation methanol fuel cells. Journal of Power Sources, 1994. 47(3): p. 377.

2. C.Y. Chen and P. Yang, Performance of an air-breathing direct methanol fuel cell. Journal of Power Sources, 2003. 123(1): p. 37.

3. A. Simoglou, Argyropoulos, P., Martin, E. B., Scott, K., Morris, A. J. and Taama, W. M., Dynamic modelling of the voltage response of direct methanol fuel cells and stacks Part I: Model development and validation. Chemical Engineering Science, 2001. 56(23): p. 6761.

4. S.C. Kelly, G.A. Deluga and W.H. Smyrl, A Miniature Methanol/Air Polymer Electrolyte Fuel Cell. Electrochem. Solid-State Lett., 2000. 3: p. 407.

5. A. Blum, T. Duvdevani, M. Philosoph, N. Rudoy, and E. Peled, Water-neutral micro direct-methanol fuel cell (DMFC) for portable applications. Journal of Power Sources, 2003. 117(1-2): p. 22.

6. T. Yamaguchi, H. Kuroki, and F. Miyata, DMFC performances using a pore-filling polymer electrolyte membrane for portable usages. Electrochemistry Communications, 2005. 7(7): p. 730.

7. W.Y. Hsu, J.R. Barkley, and P. Meakin, Ion Percolation and Insulator-to-Conductor Transition in Nafion Perfluorosulfonic Acid Membranes. Macromolecules, 1980. 13(1): p. 198-200. 
8. G. Scibona, C. Fabiani, and B. Scuppa, Electrochemical behaviour of nafion type membrane. Journal of Membrane Science, 1983. 16: p. 37.

9. H.L.a.Y. Yeager, R.S., Structural and transport properties of perfluorinated ion-exchange membrane. Mod. Aspects Electrochem., 1985. 16: p. 437.

10. P.C. Rieke and N.E. Vanderborgh, Temperature dependence of water content and proton conductivity in polyperfluorosulfonic acid membranes. Journal of Membrane Science, 1987. 32(2-3): p. 313.

11. N.a.N. Vanderborgh, T.V., The rate of isothermal hydration of polyperfluorosulfonic acid membranes. J. Membr. Sci., 1998. 143: p. 235.

12. F. Liu, B. Yi, D. Xing, J. Yu, and H. Zhang, Nafion/PTFE composite membranes for fuel cell applications. Journal of Membrane Science, 2003. 212(1-2): p. 213.

13. J.H. Shim, I.G. Koo, and W.M. Lee, Nafion-impregnated polyethylene-terephthalate film used as the electrolyte for direct methanol fuel cells. Electrochimica Acta, 2005. 50(12): p. 2385.

14. K.H. Kim, S.Y. Ahn, I.H. Oh, H.Y. Ha, S.A. Hong, M.S. Kim, Y. Lee, and Y.C. Lee, Characteristics of the Nafion ${ }^{\circledR}$-impregnated polycarbonate composite membranes for PEMFCs. Electrochimica Acta, 2004. 50(2-3 SPEC. ISS.): p. 577.

15. T. Yamaguchi, Ibe, M., Nair, B.N., Nakao, S.I., A pore-filling electrolyte membrane-electrode integrated system for a direct methanol fuel cell application. J. Electrochem. Soc., 2002. 149: p. A1448.

16. T. Yamaguchi, Hayashi, H., Kasahara, S., Nakao, S.I., Plasma-graft pore-filling electrolyte membranes using a porous poly(tetrafluoroethylene) substrate. Electrochemistry Communications, 2002. 70: p. 950.

17. T. Yamaguchi, F. Miyata, and S.-i. Nakao, Pore-filling type polymer electrolyte membranes for a direct methanol fuel cell. Journal of Membrane Science, 2003. 214(2): p. 283.

18. T. Yamaguchi, Miyata, F., Nakao, S.I., Polymer electrolyte membranes with a pore-filling structure for a direct methanol fuel cell. Adv. Mater., 2003. 15: p. 1198. 
19. C. Stone and D.A. Summers, Composite ion exchange membrane, Eur. Patent 1,263,066. 2002.

20. G. Calis, M. Hendrikus, E. Steenbakkers, and A. Hendricus, Electrolytic membrane, WO2008009430. 2008.

21. J. Qiao and T. Okada, Highly durable, proton-conducting semiinterpenetrating polymer networks from PVA/PAMPS composites by incorporating plasticizer variants. Electrochemical and Solid-State Letters, 2006. 9(8): p. A379.

22. M.M. Nasef, N.A. Zubir, A.F. Ismail, K.Z.M. Dahlan, H. Saidi, and M. Khayet, Preparation of radiochemically pore-filled polymer electrolyte membranes for direct methanol fuel cells. Journal of Power Sources, 2006. 156(2): p. 200.

23. M.M. Nasef, N.A. Zubir, A.F. Ismail, M. Khayet, K.Z.M. Dahlan, H. Saidi, R. Rohani, T.I.S. Ngah, and N.A. Sulaiman, PSSA pore-filled PVDF membranes by simultaneous electron beam irradiation: Preparation and transport characteristics of protons and methanol. Journal of Membrane Science, 2006. 268(1): p. 96.

24. L.C. Chen, T.L. Yu, H.L. Lin, and S.H. Yeh, Nafion/PTFE and zirconium phosphate modified Nafion/PTFE composite membranes for direct methanol fuel cells. Journal of Membrane Science, 2008. 307(1): p. 10.

25. H.-L. Lin, T.L. Yu, L.-N. Huang, L.-C. Chen, K.-S. Shen, and G.-B. Jung, Nafion/PTFE composite membranes for direct methanol fuel cell applications. Journal of Power Sources, 2005. 150: p. 11.

26. L.-N. Huang, L.-C. Chen, T.L. Yu, and H.-L. Lin, Nafion/PTFE/silicate composite membranes for direct methanol fuel cells. Journal of Power Sources, 2006. 161(2): p. 1096. 


\title{
Chapter 3
}

\section{I mpregnated membranes for direct methanol fuel cells at high methanol concentrations}

M. Hakan Yildirim, Alexander Schwarz, Dimitris Stamatialis, Matthias Wessling

\begin{abstract}
Sulfonated poly(phthalazinone ether ketone) (SPPEK) impregnated Solupor $\AA$, microporous film, (SPPEK-PE) and pure SPPEK membranes with two different ion-exchange capacities (IECs), were prepared and characterized for use in DMFC applications. Swelling, proton conductivity, diffusion and DMFC experiments were performed at various methanol concentrations to understand the effect of impregnation of an ion-conductive polymer membrane to the fuel cell performance.

Impregnating SPPEK into PE decreases swelling degree and methanol permeability of the membranes, but at the same time the proton conductivity. Unlike perfluorinated membranes, SPPEK-PE shows an increase in its DMFC performance at high methanol concentration and that makes it more attractive for mobile DMFC applications where high methanol concentrations are needed to compete with Li-Ion batteries.
\end{abstract}

Yildirim, M.H. et al. J. Membr. Sci., 2009. 328, p. 127. 


\section{Introduction}

The development of fuel cells has become the focus of intense worldwide R\&D activities, which is stimulated by the legislative pollution control in most industrialized countries [1]. Direct methanol fuel cells (DMFCs), which can convert the chemical energy of a fuel directly into electrical energy, have gained attention as candidates for mobile power sources to portable electronic devices [2-6].

The proton exchange membrane is the heart of DMFC. Currently, perfluorosulfonated ionomer (PFSI) membranes, like DuPont's Nafion ${ }^{\circledR}$ and Asahi Chemical's Aciplex ${ }^{\circledR}$, are used due to their excellent proton conductivity, mechanical strength and thermal and chemical stability 7-11]. However, these materials also have drawbacks like high cost (US\$700/m²) due to the expensive fluorination step and high methanol cross-over, especially at high methanol concentrations. In order to compete with Li-ion batteries for portable applications, higher power densities must be achieved. For that reason DMFCs should be operated at high methanol concentrations [12]. Therefore there is a strong need to develop new membrane materials, which would have low methanol cross-over and high dimensional stability

To achieve a membrane stable at high methanol concentration, one strategy would be impregnation of a conductive polymer into a porous support [1316]. In fact, we showed previously that excessive swelling of the membrane can be suppressed by impregnation of Nafion into polyethylene porous support, while the methanol cross-over can be minimized [17]. An alternative strategy to minimize methanol crossover is by using a polymer with low methanol cross-over such as Sulfonated Poly(Phthalazinone Ether Ketone) (SPPEK). Its low methanol cross-over and reasonable proton conductivity make it attractive for hydrogen and methanol fuel cells $[1,17$ 21]. In this study we combine both strategies, in fact we impregnate SPPEK polymer into a polyethylene support, Solupor ${ }^{\circledR}$ microporous film, (SPPEK$\mathrm{PE}$ ) aiming to decrease the methanol cross over and cost, and at the same time to increase their dimensional stability and fuel cell performance. The composite membranes are systematically characterized with respect to their swelling degree, proton conductivity, methanol permeability and DMFC performance at various methanol concentrations. For comparison, the performance of Nafion ${ }^{\circledR} 117$ (N117), Nafion impregnated PE (N-PE) and pure SPPEK membranes is also investigated. 


\section{Experimental}

2.1. Materials and membrane preparation

Materials

SPPEK-polymers (Fig. 1), with two different ion-exchange capacities (IECs) (1.4 and $1.6 \mathrm{mmol} / \mathrm{g}$ ), were kindly provided by FuMA-Tech $\mathrm{GmbH}$ (Germany). For the composite membranes a porous PE film, Solupor ${ }^{\circledR}$ microporous UHMWPE, (provided by DSM Solutech), with a thickness of 13 $\mu \mathrm{m}$, mean flow pore size of $0.7 \mu \mathrm{m}$, and porosity of $85 \%$, was used. The density of $\mathrm{PE}$ is $0.97 \mathrm{~g} / \mathrm{cm}^{3}$. N117 membranes $(185 \mu \mathrm{m}$ and 1100 equivalent weight (EW)) were purchased from Aldrich (Germany). N-Methyl-2Pyrrolidone (NMP) was purchased from Aldrich (Germany). E-TEK electrodes were purchased from E-TEK DeNora (U.S.A.).

\section{Preparation of SPPEK membranes}

The SPPEK polymers were dissolved in NMP to obtain 10wt\%-solutions. The mixture, SPPEK/NMP, was stirred over night in the fumehood to get a homogenous solution. After dissolving, the solutions were filtered with metal mesh filters first with $40 \mu \mathrm{m}$ and afterwards with $15 \mu \mathrm{m}$ pore size to remove undissolved and dirt particles. The solution was cast on a glass plate with a casting knife of $0.5 \mathrm{~mm}$ to get dense membranes with a thickness of $50 \mu \mathrm{m}$. The membranes were dried in the fumehood for 3 days, and afterwards in an oven for 5 days at $80^{\circ} \mathrm{C}$. To remove the remaining NMP, they were placed in demineralized water for one day; the water was exchanged several times. The membranes were dried for 5 days under vacuum at $30^{\circ} \mathrm{C}$ and finally were stored in a dry place at room temperature.

\section{Preparation of SPPEK-PE composite membranes}

A 10wt\% SPPEK/NMP solution was used for the impregnation. A PE-film $(30 \times 15 \mathrm{~cm})$ was fixed on a glass frame with scotch tape. For the impregnation of the PE substrate, an airbrush gun with a $0.5 \mathrm{~mm}$ nozzle was used. The gas pressure was set to 2 bar. After filling $20 \mathrm{ml}$ of the solution into the airbrush gun, the PE film was impregnated at a distance of $10 \mathrm{~cm}$ from both sides $(10 \mathrm{ml}$ solution at each side). The impregnated membranes were dried in the same way as the SPPEK membranes (see earlier). 


\subsection{Membrane characterization}

Scanning electron microscopy (SEM)

Membranes were visualized by a scanning electron microscope (Jeol JSM $5600 \mathrm{LV})$. The membrane samples were sputtered with a thin layer of gold (30 nm) using a Balzers Union SCD 040 sputtering device prior to the SEM observation.

Porosity of the composite membrane

The porosity of the N-PE membrane, $\varphi_{p}(\%)$, was estimated using the equation [12]:

$$
\varphi_{P}=\left\{1-\frac{\frac{w_{f p}^{d}}{\rho_{f p}}+\frac{w_{s u b}^{d}}{\rho_{P E}}}{V_{m e m}^{d}}\right\} .100
$$

where $w_{f p}^{d}$ weight of the dry Nafion ${ }^{\circledR}, w_{s u b}^{d}$ weight of the dry poly(ethylene) substrate, $\rho_{f p}$ the density of Nafion ${ }^{\circledR}, \rho_{P E}$ the density of $\mathrm{PE}$, and $V_{m e m}^{d}$ is the dry membrane volume estimated from the geometric membrane area $(A)$ and thickness $(l)$.

Swelling degree (SD)

Membranes were dried in the vacuum oven at $30^{\circ} \mathrm{C}$ for 1 day and then immersed in ultra pure water or methanol solutions of various concentrations. The weight and the area of the wet (Value wet $_{\text {) }}$ and the dry (Valuedry) samples were measured. The SD of the membrane was calculated using: 


$$
S D(\%)=\left(\frac{\text { Value }_{\text {wet }}-\text { Value }_{d r y}}{\text { Value }_{d r y}}\right) \cdot 100,
$$

Methanol permeability

The methanol permeability, $\mathrm{P}\left[\mathrm{cm}^{2} / \mathrm{s}\right]$, at $25^{\circ} \mathrm{C}$ was measured using a two compartment diffusion cell following the procedure described elsewhere [13].

Proton conductivity

The proton conductivity measurements were performed by impedance spectroscopy in a home-made cell following the procedure described elsewhere [13]. Prior to all experiments, membranes were equilibrated for $24 \mathrm{~h}$ in ultra pure water and various methanol solutions (from $1 \mathrm{M}$ to $10 \mathrm{M}$ ).

\subsection{Fabrication of membrane-electrode assemblies}

E-TEK commercial electrodes were used to fabricate the membraneelectrode assemblies (MEAs). Both anode and cathode contain $5 \mathrm{mg} / \mathrm{cm}^{2} \mathrm{Pt}$ $\mathrm{Ru}$ and Pt, respectively. For both electrodes DE2020 Nafion ${ }^{\circledR}$ dispersion was used as a binder layer. The Nafion loading was about $1.2 \mathrm{mg} / \mathrm{cm}^{2}$. The geometric area of each electrode was $6.25 \mathrm{~cm}^{2}$. The MEAs were prepared by hot pressing of the anode and cathode on both sides of the membrane with a pressure of 10 bar for 5 minutes at $120^{\circ} \mathrm{C}$.

\subsection{Single cell DMFC performance}

The performance of the MEAs was evaluated using a DMFC set-up constructed by the Energy Research Centre (ECN, The Netherlands). The MEA was clamped between two graphite blocks. A serpentine flow pattern is etched in each of the graphite blocks to provide fuel to the MEA. Both graphite blocks were connected with electrical wires to an adjustable electrical load. The cell was thermostated with a heating bath and the temperature of the cell was measured with a thermocouple. The methanol solution was fed to the anode at flow rates of $20 \mathrm{ml} / \mathrm{min}$ and dry oxygen was fed to the cathode at flow rates of $75 \mathrm{ml} / \mathrm{min}$ and back pressure of 2 bar. The temperature of the cell was kept at $80^{\circ} \mathrm{C}$. Polarization curves were measured by applying different currents and measuring the correspondent cell voltages. The current was increased step by step till the cell voltage became 
zero. The equilibration time between the measured points was at least 30 seconds and the difference between the voltages in the last two seconds of each point was less than $1 \mathrm{mV}$.

\section{Results and discussion}

\subsection{SEM study of SPPEK-PE composite membrane}

Figure 2 shows SEM images of the cross-section of SPPEK-PE composite membrane. SPPEK-PE membrane consists of an impregnated middle layer of about $13 \mu \mathrm{m}$ and two layers of pure conductive polymer at the top and bottom $(\sim 2-3 \mu \mathrm{m})$. The porosity of the pure PE film is $85 \%$ according to the manufacturer. The porosity of the middle layer of the composite membrane was estimated (using Eq. 1) to be $30 \%$. This indicates that the impregnation is rather incomplete and air might be trapped in the non-filled pores of the substrate. In our previous work [13], we studied commercial Nafion impregnated PE membrane with similar porosity ( 27\%). Those membranes had superior DMFC performance than N117 membranes.
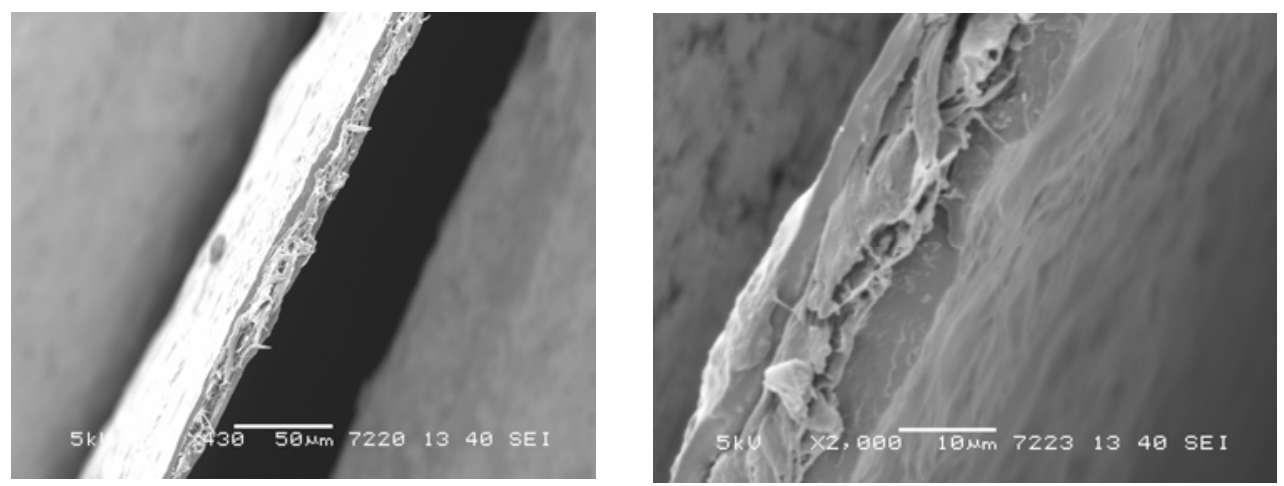

Figure 2. SEM images of cross-sections of the SPPEK-PE composite membranes.

\subsection{Swelling experiments}

Figure 3 shows the swelling degree (SD) of all membranes as a function of time in ultra pure water (Fig. 3a) and $10 \mathrm{M} \mathrm{MeOH}$ (Fig. 3b). After 24h, the swelling degree remains constant. It seems that the membranes soaked the maximum amount of water or methanol within the first day. The swelling of all membranes is higher in $10 \mathrm{M} \mathrm{MeOH}$ solution than in ultra pure water. In 
all cases SPPEK1.6 swells more than SPPEK1.4 due to its higher ionexchange capacity. The swelling of the impregnated membranes are lower than pure membranes due to the presence of hydrophobic PE substrate.
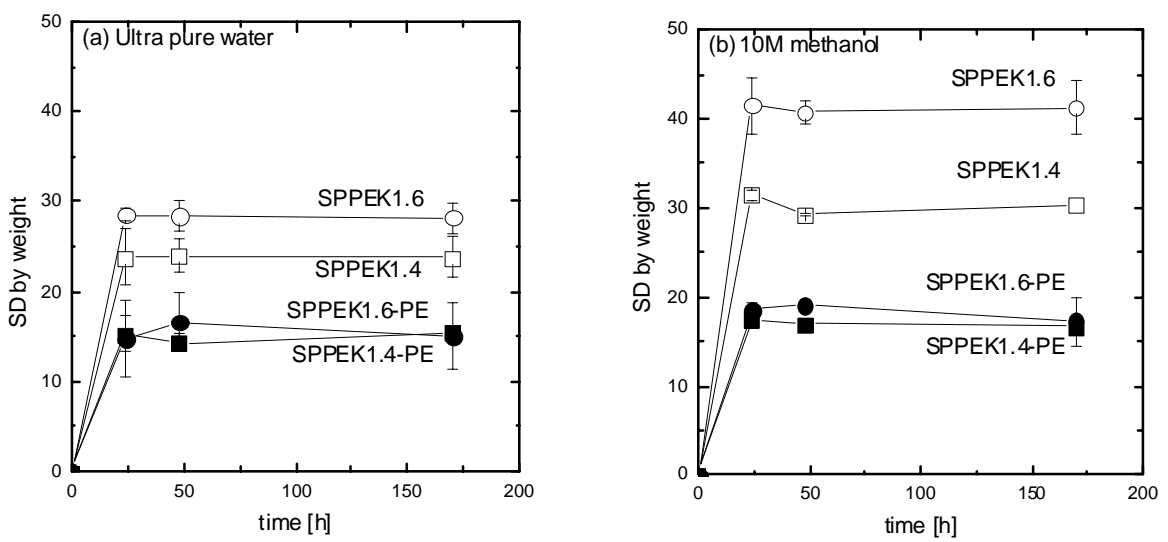

Figure 3. Swelling degrees by weight in (a) ultra pure water and (b) 10M methanol solution.

Figure $4 \mathrm{a}$ and $4 \mathrm{~b}$ show the results of the SD by weight and area, respectively, of all membranes at various methanol concentrations. Swelling by weight of SPPEK1.4 and SPPEK1.6 show a slight increase till $6 \mathrm{M}$ and then increase more sharply up to $10 \mathrm{M}$ methanol concentration (especially, the SPPEK1.6) (Fig. 4a). Swelling by weight of SPPEK1.6 is higher than SPPEK1.4 due to its higher ion-exchange capacity. For comparison, the swelling by weight of N117 and N-PE membranes are much higher than SPPEK and SPPEK-PE membranes at high concentrations and they are in the range of $70 \%$ and $50 \%$, respectively [13].

Swelling by weight of both composite membranes (SPPEK1.4-PE and SPPEK1.6-PE) is independent of methanol concentration and almost factor of two lower than the pure SPPEK1.4 and SPPEK1.6 membranes. This is probably due to the suppression of the swelling degree of the composite membranes by the PE substrate.

In Figure 4b, one can see similar trends concerning the swelling by area of the various membranes. At higher methanol concentrations, the SD by area of the SPPEK1.4 and SPPEK1.6 increases, but of the composite membranes 
stay constant and most importantly is very low (5-10\%). Even at $10 \mathrm{M}$ methanol concentration the dimensional stability of composite membranes is high; the PE support effectively suppresses swelling in the area direction. For comparison, the swelling by area of N117 membrane is much higher than SPPEK and SPPEK-PE membranes at high concentrations and it in the range of $40 \%$. The N-PE shows a significantly low swelling in the area direction, like SPPEK1.4-PE composite membrane, even at high methanol concentrations and it is about $5 \%$ [13].
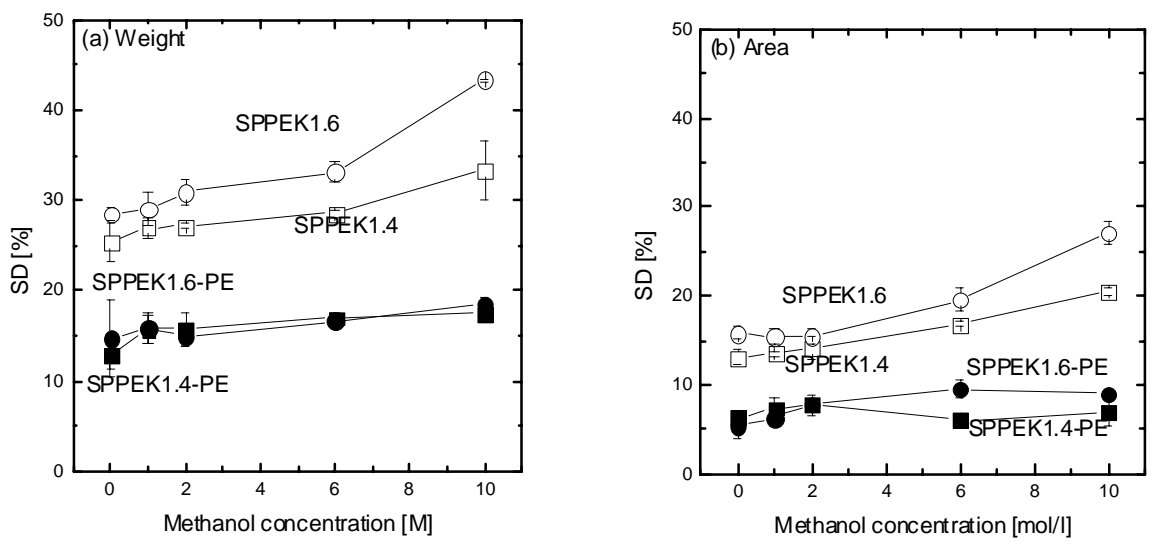

Figure 4. Swelling degrees (a) by weight and (b) area as a function of methanol concentration.

\subsection{Methanol permeability}

High methanol crossover from the anode to the cathode is detrimental to the fuel cell performance as it reduces the efficiency and cell voltage. Figure $5 \mathrm{a}$ and $5 \mathrm{~b}$ show methanol permeabilities of pure and composite SPPEK membranes in comparison to $\mathrm{N} 117$ and N-PE membranes [13] as a function of methanol concentration.

SPPEK and SPPEK-PE membranes have one order of magnitude lower methanol permeability than $\mathrm{N} 117$ and N-PE membranes. This is an advantage of these membranes, because the efficiency losses caused by methanol crossover are expected to be much lower. We think that the difference in methanol transport between the two cases is due to the difference in chemical structures of Nafion and SPPEK polymers. The 
microstructure of N117 (and generally of perfluorosulfonic polymers) consists of extremely hydrophobic backbone and extremely hydrophilic sulfonic groups. In the presence of water, the hydrophilic sulfonic groups aggregate to form ion clusters, which form the water channels with good connectivity. Compared with Nafion, the backbone of SPPEK is less hydrophobic and the sulfonic groups are less acidic. This results in larger hydrophobic-hydrophilic interface corresponding to highly disperse sulfonic groups and less nano-separation. Thus, the water filled channels in SPPEK are probably more branched with more dead-end pockets compared with those of Nafion. This results in low methanol and water transport and lower proton conductivity (as we see later). In addition to that, the methanol permeability of SPPEK-PE composite membranes is factor of 2 to 3 lower than pure SPPEK membranes showing once more that the impregnation to the support is an effective method to lower methanol permeability. The same phenomenon has been reported by Yamaguchi et al. with other filling electrolytes into various supports [12, 22].
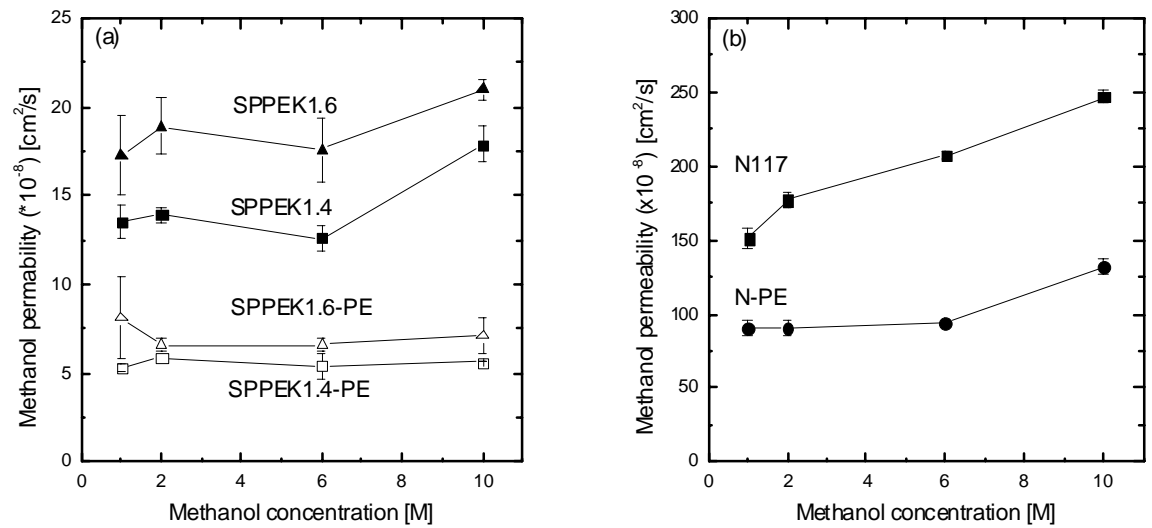

Figure 5. Methanol permeabilities of (a) SPPEK, (b) N117 and N-PE membranes as a function of methanol concentration (Data from N117 and N-PE are replotted from [13] ).

\subsection{Proton conductivity}

The proton conductivity or our membranes are generally low and in the

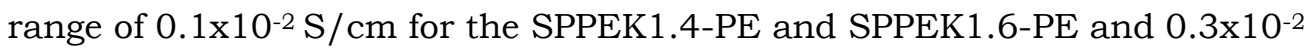
$\mathrm{S} / \mathrm{cm}$ for the SPPEK1.4 and SPPEK1.6 membranes. In general, the values of SPPEK membranes are in the lower range with values reported in literature $\left(0.2\right.$ to $\left.5.0 \times 10^{-2} \mathrm{~S} / \mathrm{cm}\right)[1,17,18,20,23]$. Although one should be careful 
with the experimental conditions used there. Many parameters can influence the proton conductivity i.e. pre-treatment, casting solvent, etc. For example, in literature N,N-Dimethylacetamide (DMAc) was often used as a casting solvent $[19,21]$, while our membranes were prepared in NMP.

Figure 6 shows the proton conductivities of the membranes as a function of methanol concentration. Proton conductivities of SPPEK1.4 and SPPEK1.6 are in the same range for methanol concentration up to 6M. At higher methanol concentration, the proton conductivity of SPPEK1.6 increases sharply, whereas increases modestly for SPPEK1.4. SD measurements show the same effect. The rate of increase is smaller for SPPEK1.4 than SPPEK1.6. It seems that there is a threshold for swelling as well as conductivity at $\sim 6 \mathrm{M}$ especially for the SPPEK1.6 membrane. This phenomenon is not observed for the SPPEK-PE impregnated membranes. The conductivity of those membranes is independent of the methanol concentration at around $0.1 \times 10^{-2} \mathrm{~S} / \mathrm{cm}$ (Fig. 6) and a factor 3 lower than pure membranes, due to the presence of the non-conductive PE material. For comparison, the proton conductivities of N117 and N-PE membranes are much higher and they are in the range of $5-6 \times 10^{-2} \mathrm{~S} / \mathrm{cm}$ and $0.5-3 \times 10^{-2}$ $\mathrm{S} / \mathrm{cm}$, respectively for methanol concentrations of 1-10M [13].

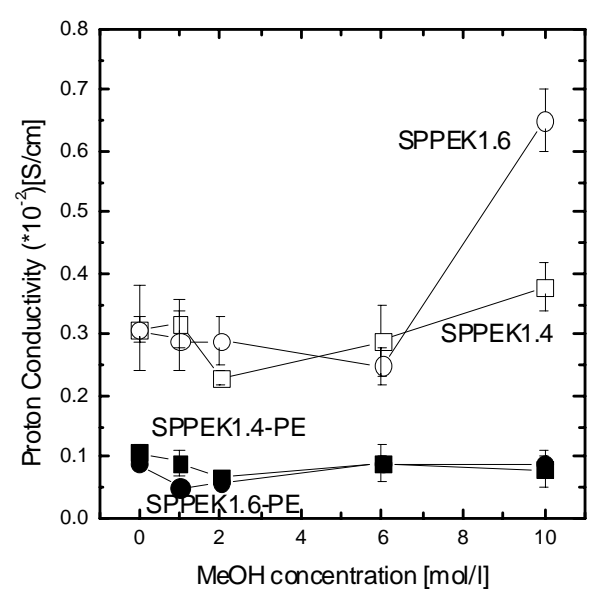

Figure 6. Proton conductivities of SPPEK membranes as a function of methanol concentration.

3.5. Single cell performance

SPPEK1.4 and SPPEK1.4-PE membranes were selected for further tests in the DMFC due to their low swelling and methanol cross-over. MEAs were 
prepared by hot pressing two E-TEK commercial electrodes on both sides of the membranes at 10bar. At least two MEAs were prepared and measured for each methanol concentration. Minimum 70 polarization curves were measured for each MEA and the values presented in this work are their average values.
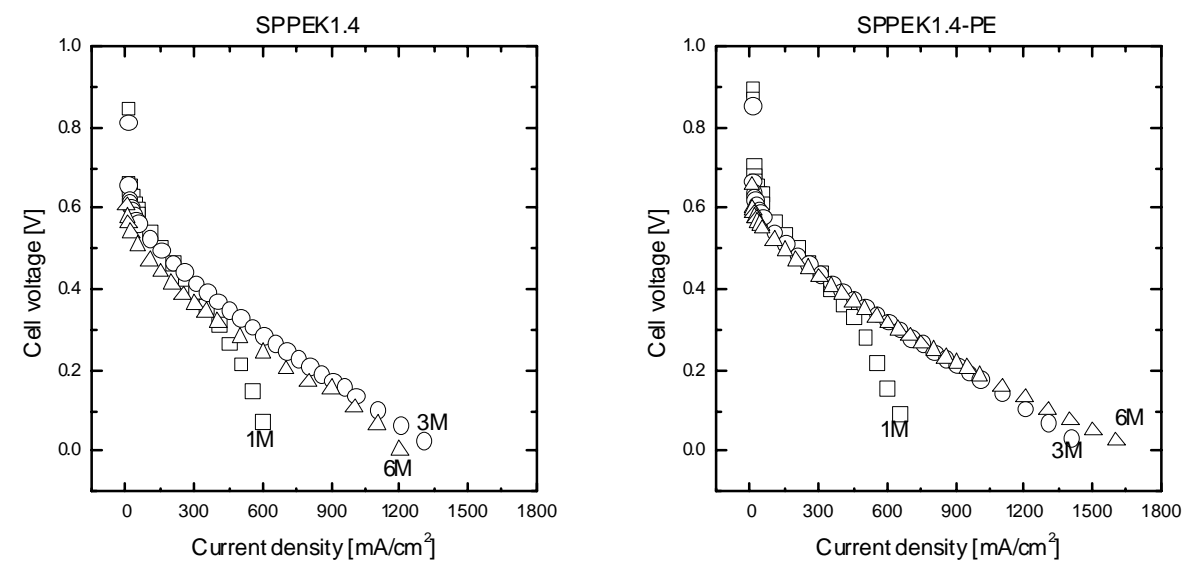

Figure 7. Polarization curves of SPPEK1.4 and SPPEK1.4-PE membranes at various methanol concentrations.

Figure 7 presents polarization curves of SPPEK1.4 and SPPEK1.4-PE membranes at various methanol concentrations. The open cell voltage (OCV) values of each membrane decreases at higher methanol concentration due to the increasing driving force for the methanol cross-over. In all graphs, there are clear regions of activation, ohmic and concentration polarization. The concentration polarization is significant at $1 \mathrm{M}$, but becomes lower at $3 \mathrm{M}$ and $6 \mathrm{M}$. For SPPEK1.4 membrane, it seems that the performance at $6 \mathrm{M}$ is slightly worse than at 3M. However, for the SPPEK1.4-PE, the performance at $6 \mathrm{M}$ is better than $3 \mathrm{M}$. In fact, the impregnated membrane can be used up to $1600-1700 \mathrm{~mA} / \mathrm{cm}^{2}$ at high methanol concentrations. This is also obvious when comparing the power density curves of the membranes at various methanol concentrations (see Fig. 8). SPPEK1.4-PE composite membrane shows superior performance than SPPEK1.4 membrane at every concentration and at low and high current density regions of the curves due to its significantly low methanol cross-over and reasonable proton conductivity. Since the composite membrane has significantly low methanol cross- 
over, the performance increases with increasing methanol concentration, which is also an advantage over the perfluorinated Nafion based membranes.
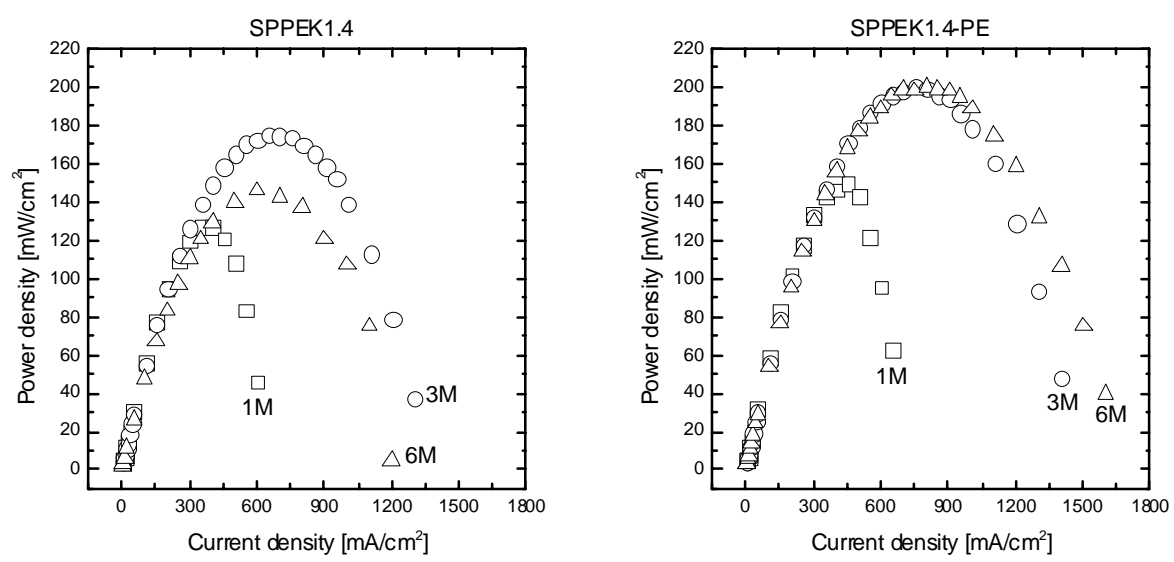

Figure 8. Power density curves of SPPEK1.4 and SPPEK1.4-PE membranes at various methanol concentrations.

Figure 9 summarizes the DMFC measurements of this study and compares our results with our previous study for N117 and N-PE membranes [13]. It presents the maximum power densities as a function of methanol concentration at the anode side of the fuel cell (lines are used to guide the eye of the reader and do not correspond to experimental result). The power density of the N117 and N-PE is higher than SPPEK1.4 and SPPEK1.4-PE at $1 \mathrm{M}$, but decreases sharply at $6 \mathrm{M}$. The maximum power density of SPPEK1.4 increases with increasing methanol concentration up to $3 \mathrm{M}$ and then shows a slight decrease at $6 \mathrm{M}$, but the power density at $6 \mathrm{M}$ is still higher than $1 \mathrm{M}$. The power density of the SPPEK1.4-PE is always higher than SPPEK1.4 and interestingly is independent of methanol concentration above 3M. The performance of the SPPEK1.4-PE composite membrane at 6M is higher not only than the pure SPPEK1.4 membrane, but also significantly higher than those results of $\mathrm{N} 117$ and N-PE membranes at $6 \mathrm{M}$. This shows that the SPPEK1.4-PE membrane is a very promising material for DMFC applications at high methanol concentrations. In order to compete with $\mathrm{Li}$ Ion batteries, high methanol concentrations should be used as a fuel in DMFCs and SPPEK1.4-PE is the best material at $6 \mathrm{M}$ in comparison to all the other materials we have tested. 


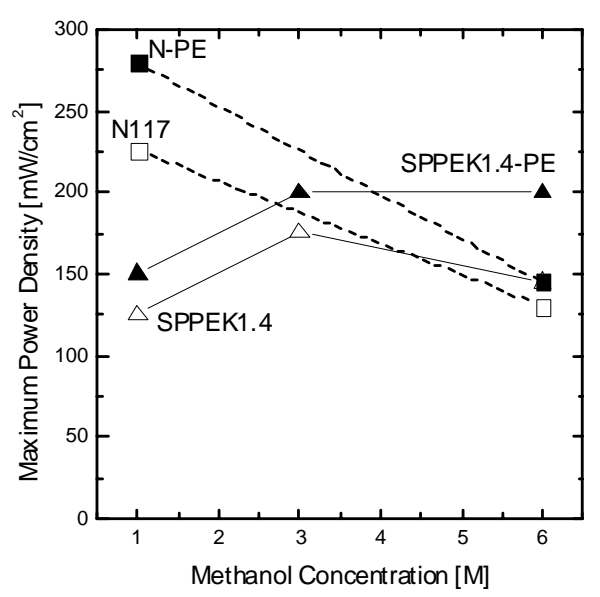

Figure 9. Maximum power densities of SPPEK1.4 and SPPEK1.4-PE as a function of methanol concentration (Data from N117 and N-PE are replotted from [13] ).

\section{Conclusions}

In the present work, SPPEK and SPPEK-PE membranes, with two different IECs, were prepared and characterized for use in DMFC applications. Swelling, proton conductivity, diffusion and DMFC experiments were performed to understand the effect of impregnation of a conductive polymer into a non-conductive porous substrate.

The swelling of the composite membrane is very low. Diffusion measurements show that the methanol permeability of SPPEK-PE is one order of magnitude lower than $\mathrm{Nafion}^{\circledR}$ and N-PE membranes and a factor 2 lower than pure SPPEK membrane. The proton conductivity, however, is rather low at $1 \mathrm{mS} / \mathrm{cm}^{2}$. It seems, however, that the substantially low methanol cross-over compensates the low proton conductivity and therefore the composite membrane shows superior performance than SPPEK, N117 and N-PE membranes at high methanol concentrations (6M). Unlike perfluorinated membranes, SPPEK-PE shows an increase in its DMFC performance with increasing methanol concentration and this makes it more attractive material for mobile DMFC applications where high methanol concentrations are needed to compete with Li-Ion batteries. 


\section{Acknowledgements}

This research was financially supported by the Dutch Technology Foundation STW (Project no: 5713). The authors wish to thank:

- Dr. Bernd Bauer (FuMA-Tech GmbH, Germany) for supplying the SPPEK polymer solutions and discussions concerning this work.

- Dr. Gijs Calis and Ir. Harold Smelt (DSM Solutech, The Netherlands) for supplying the PE porous substrate and discussions concerning this work.

- Dr. Bernard Boukamp (University of Twente) for building the conductivity set-up.

- Dr. Ronald Mallant (ECN, The Netherlands) for discussions concerning this work.

\section{References}

1. Gao, Y., Robertson, G.P., Guiver, M.D., Jian, X., Mikhailenko, S.D., Wang, K., and Kaliaguine, S., Sulfonation of poly(phthalazinones) with fuming sulfuric acid mixtures for proton exchange membrane materials. Journal of Membrane Science, 2003. 227(1-2): p. 39.

2. Blum, A., Duvdevani, T., Philosoph, M., Rudoy, N., and Peled, E., Water-neutral micro direct-methanol fuel cell (DMFC) for portable applications. Journal of Power Sources, 2003. 117(1-2): p. 22.

3. Simoglou, A., Argyropoulos, P., Martin, E. B., Scott, K., Morris, A. J. and Taama, W. M., Dynamic modelling of the voltage response of direct methanol fuel cells and stacks Part I: Model development and validation. Chemical Engineering Science, 2001. 56(23): p. 6761.

4. Chen, C.Y. and Yang, P., Performance of an air-breathing direct methanol fuel cell. Journal of Power Sources, 2003. 123(1): p. 37.

5. Surampudi, S., Narayanan, S. R., Vamos, E., Frank, H., Halpert, G., LaConti, A., Kosek, J., Prakash, G. K. Surya, and Olah, G. A., Advances in direct oxidation methanol fuel cells. Journal of Power Sources, 1994. 47(3): p. 377. 
6. Kelly, S.C., Deluga, G.A. and Smyrl, W.H., A Miniature Methanol/Air Polymer Electrolyte Fuel Cell. Electrochem. Solid-State Lett., 2000. 3: p. 407.

7. Rieke, P.C. and Vanderborgh, N.E., Temperature dependence of water content and proton conductivity in polyperfluorosulfonic acid membranes. Journal of Membrane Science, 1987. 32(2-3): p. 313.

8. Scibona, G., Fabiani, C., and Scuppa, B., Electrochemical behaviour of nafion type membrane. Journal of Membrane Science, 1983. 16: p. 37.

9. Hsu, W.Y., Barkley, J.R., and Meakin, P., Ion Percolation and Insulator-to-Conductor Transition in Nafion Perfluorosulfonic Acid Membranes. Macromolecules, 1980. 13(1): p. 198-200.

10. Vanderborgh, N. and Nguyen, T.V., The rate of isothermal hydration of polyperfluorosulfonic acid membranes. J. Membr. Sci., 1998. 143: p. 235.

11. Yeager, H.L. and Yeo, R.S., Structural and transport properties of perfluorinated ion-exchange membrane. Mod. Aspects Electrochem., 1985. 16: p. 437.

12. Yamaguchi, T., Kuroki, H., and Miyata, F., DMFC performances using a pore-filling polymer electrolyte membrane for portable usages. Electrochemistry Communications, 2005. 7(7): p. 730.

13. Yildirim, M.H., Stamatialis, D., and Wessling, M., Dimensionally stable Nafion-polyethylene composite membranes for direct methanol fuel cell applications. J. Membr. Sci., 2008. 321 (2): p. 364.

14. Kim, K.H., Ahn, S.Y., Oh, I.H., Ha, H.Y., Hong, S.A., Kim, M.S., Lee, Y., and Lee, Y.C., Characteristics of the Nafion ${ }^{\circledR}$-impregnated polycarbonate composite membranes for PEMFCs. Electrochimica Acta, 2004. 50(2-3 SPEC. ISS.): p. 577.

15. Liu, F., Yi, B., Xing, D., Yu, J., and Zhang, H., Nafion/PTFE composite membranes for fuel cell applications. Journal of Membrane Science, 2003. 212(1-2): p. 213.

16. Shim, J.H., Koo, I.G., and Lee, W.M., Nafion-impregnated polyethylene-terephthalate film used as the electrolyte for direct methanol fuel cells. Electrochimica Acta, 2005. 50(12): p. 2385. 
17. Gao, Y., Robertson, G.P., Guiver, M.D., Jian, X., Mikhailenko, S.D., and Kaliaguine, S., Proton exchange membranes based on sulfonated poly(phthalazinone ether ketone)s/aminated polymer blends. Solid State Ionics, 2005. 176(3-4): p. 409.

18. Su, Y.-H., Liu, Y.-L., Sun, Y.-M., Lai, J.-Y., Guiver, M.D., and Gao, Y., Using silica nanoparticles for modifying sulfonated poly(phthalazinone ether ketone) membrane for direct methanol fuel cell: A significant improvement on cell performance. Journal of Power Sources, 2006. 155(2): p. 111.

19. Zhang, H., Zhu, B., and Xu, Y., Composite membranes of sulfonated poly(phthalazinone ether ketone) doped with 12-phosphotungstic acid (H3PW12O40) for proton exchange membranes. Solid State Ionics, 2006. 177(13-14): p. 1123.

20. Tian, S.H., Shu, D., Chen, Y.L., Xiao, M., and Meng, Y.Z., Preparation and properties of novel sulfonated poly(phthalazinone ether ketone) based PEM for PEM fuel cell application. Journal of Power Sources, 2006. 158(1): p. 88.

21. Sun, Y.-M., Wu, T.-C., Lee, H.-C., Jung, G.-B., Guiver, M.D., Gao, Y., Liu, Y.-L., and Lai, J.-Y., Sulfonated poly(phthalazinone ether ketone) for proton exchange membranes in direct methanol fuel cells. Journal of Membrane Science, 2005. 265(1-2): p. 108.

22. Yamaguchi, T., Miyata, F., and Nakao, S.-i., Pore-filling type polymer electrolyte membranes for a direct methanol fuel cell. Journal of Membrane Science, 2003. 214(2): p. 283.

23. Gao, Y., Robertson, G.P., Guiver, M.D., Wang, G., Jian, X., Mikhailenko, S.D., Li, X., and Kaliaguine, S., Sulfonated copoly(phthalazinone ether ketone nitrile)s as proton exchange membrane materials. Journal of Membrane Science, 2006. 278(1-2): p. 26 . 


\title{
Chapter 4
}

\section{Nafion ${ }^{\circledR} /$ H-ZSM-5 composite membranes with superior performance for direct methanol fuel cells}

M. Hakan Yildirim, Anna Roca Curòs, Julius Motuzas, Anne Julbe,

Dimitris Stamatialis, Matthias Wessling

\begin{abstract}
Solution cast composite direct methanol fuel cell membranes (DEZ) based on DE2020 Nafion ${ }^{\circledR}$ dispersion and in house prepared H-ZSM-5 zeolites with different $\mathrm{Si} / \mathrm{Al}$ ratios were prepared to increase the proton conductivity and decrease the methanol cross-over at the same time.

All composite membranes have indeed lower methanol permeability and higher proton conductivity than pure DE2020 membrane. The composite membranes with $\mathrm{Si} / \mathrm{Al}$ ratio 25 and $5 \mathrm{wt} . \%$ of zeolites (DEZ25-5) having the lowest methanol permeability and the membrane with $\mathrm{Si} / \mathrm{Al}$ ratio 50 and 1wt.\% of zeolites (DEZ50-1) having the highest proton conductivity are tested in the direct methanol fuel cell (DMFC) for several days. At the end of the 5th day it seems that DEZ25-5 has the best performance namely high power density and stable performance in time with low fluctuations.
\end{abstract}

Yildirim, M.H. et al. J. Membr. Sci., submitted for publication. 


\section{Introduction}

Direct methanol fuel cells (DMFCs) gain recently attention as candidates for mobile power sources to portable electronic devices [1-5] due to their high energy density and easy and significantly fast charging times.

In order to increase the proton conductivity and decrease the methanol cross-over of the electrolyte membrane, zeolites can be used. Zeolites have two important properties: 1 . they have very high water retention ability, which can only be eliminated at around $200^{\circ} \mathrm{C}$ and 2. they have molecular sieving properties, which can help to selective separations based on molecular size and shape [6-8]. Unfortunately, membranes made of pure zeolites suffer from the brittleness, fragility and defects [9]. Therefore composite membranes can be made using zeolites as fillers and a polymeric matrix as a host. If the zeolites are well dispersed in the matrix, they can serve as extra route for proton transport in the membrane in addition to the already existing water channels. This leads to increase of the membrane conductivity and at the same time, the tortuous pathway, created by the zeolites, can decrease the methanol cross-over.

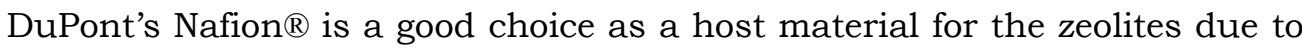
its excellent proton conductivity, mechanical strength and thermal and chemical stability [10-14]. In fact, researchers made already several attempts to prepare and characterize Nafion/zeolite composite membranes for DMFC applications [15-17]. In most cases the proton conductivity and methanol cross-over is reported without DMFC results. The ratio of proton conductivity and methanol permeability (often indicated as " $\beta$ ") is then used to predict DMFC performance. As we showed in earlier study [18], very often $\beta$ value has very low predictive power.

In this study, $\mathrm{H}-\mathrm{ZSM}-5$ zeolites with various $\mathrm{Si} / \mathrm{Al}$ ratios are prepared in house using microwaves-assisted heating. Then, they are incorporated into Nafion membranes at various loadings (1, 3 and 5 wt \%). All composite membranes are tested with respect to swelling degree, proton conductivity and methanol permeability. Selected membranes with the highest proton conductivity and lowest methanol cross-over are tested fro several days in DMFC. For comparison, the performance of pure DE2020 (membrane prepared using DE2020 Nafion ${ }^{\circledR}$ dispersion) membranes are also investigated. 


\section{Experimental}

\subsection{Materials}

DE2020 Nafion ${ }^{\circledR}$ dispersion (20wt. \% Nafion ${ }^{\circledR}+80$ wt. \% water and VOCs, 1000 equivalent weight (EW)) was purchased from Ion Power Inc. (U.S.A.). DMSO was purchased from Aldrich (Germany). E-TEK electrodes were purchased from E-TEK DeNora (U.S.A.). Aluminum sulfate hexadecanohydrate $\left(\mathrm{Al}_{2}\left(\mathrm{SO}_{4}\right)_{3} * 16 \mathrm{H}_{2} \mathrm{O}, 98 \%\right)$ and tetraethylorthosilicate (TEOS, 98\%) was purchased from Aldrich. Tetrapropylammonium hydroxide (TPAOH, 20\% aqueous solution) was purchased from Sigma.

\subsection{Seeds synthesis}

Polymer-zeolite composite membranes can be prepared using small zeolite crystals obtained by milling of big crystals. A precise control of the process parameters is needed for controlling crystal size and homogeneity. Besides, nanosized zeolite crystals can be prepared by hydrothermal synthesis, although long ageing times and/or durations are generally required for obtaining small and uniform crystal sizes by conventional heating methods $[19,20]$. Microwaves-assisted heating is an attractive strategy for reducing synthesis time and obtaining uniform nanocrystals [21].

In the present study microwave heating is used to prepare ZSM-5 nanosized crystals within a few hours, starting from sol with a $\mathrm{Si} / \mathrm{Al}$ molar ratio in the range $25-100$. Mother sols were prepared by mixing TEOS $(98 \%)$, ultrapure water (18.2 $\mathrm{M} \Omega)$ and TPAOH $\left(20 \%\right.$ aqueous solution). $\mathrm{Al}_{2}\left(\mathrm{SO}_{4}\right)_{3}{ }^{*} 16 \mathrm{H}_{2} \mathrm{O}(98 \%)$ was used as $\mathrm{Al}$ precursor. The mother sol composition was: $\mathrm{xAl}_{2} \mathrm{O}_{3}: 1 \mathrm{SiO}_{2}$ : $0.4 \mathrm{TPAOH}: 19.5 \mathrm{H}_{2} \mathrm{O}: 4 \mathrm{C}_{2} \mathrm{H}_{5} \mathrm{OH}$. The alumina concentration $\mathrm{x}$ was varied in the range 0.05-0.2 ( $\mathrm{Si} / \mathrm{Al}=25-100)$ in the mother sol. Sols were aged at room temperature $\left(25^{\circ} \mathrm{C}\right)$ under stirring for $24 \mathrm{~h}$ in air. A sol quantity of about 20 $\mathrm{g}$ was used for each experiment. The microwave assisted hydrothermal (MW-HT) synthesis of seeds was performed in two steps as reported by Motuzas et al. [21], using computer controlled Milestone ETHOS 1600 MW oven. The synthesis parameters have been chosen as follows - for the first step $\mathrm{T}_{1}=80^{\circ} \mathrm{C}, \mathrm{t}_{1}=90 \mathrm{~min}, \mathrm{P}_{1}=250 \mathrm{~W}$ and for the second step $\mathrm{T}_{2}=160^{\circ} \mathrm{C}, \mathrm{t}_{2}=60$ min, $\mathrm{P}_{2}=400 \mathrm{~W}$. After synthesis, the suspensions were cooled to $50-60^{\circ} \mathrm{C}$ and removed from the autoclave. This cooling step occurred by classical convection and lasted typically 30 to $40 \mathrm{~min}$. 
The solid product was separated from the liquid phase by centrifugation at $9500 \mathrm{rpm}$ (JOUAN B4i), washed twice with distilled water and centrifuged in order to reach a neutral $\mathrm{pH}$. The recovered solid product was dried for 4 hours at $155^{\circ} \mathrm{C}$ and calcined at $550^{\circ} \mathrm{C}$ during $4 \mathrm{~h}$ with a slope up and down of $0.5{ }^{\circ} \mathrm{C} / \mathrm{min}$. The phase purity and dimensions of the calcined crystals were respectively characterized by X-ray diffraction and scanning electron microscopy.

\subsection{Membrane preparation}

A predetermined amount of zeolite was added to $10 \mathrm{~g}$ of DMSO and sonicated for 1-2 $\mathrm{h}$ in an ultrasonic bath to disperse the zeolite. Then $50 \mathrm{~g}$ of DE2020 Nafion ${ }^{\circledR}$ dispersion was added and mixed vigorously for $1 \mathrm{~h}$. After that it was cast on Teflon plate with a casting knife and placed in the fumehood for 18 hours. The obtained membrane was annealed at $150^{\circ} \mathrm{C}$ for 1 hour and then was peeled off from the Teflon plate. Membranes of dry thickness of $50 \mu \mathrm{m}$ and with zeolite content of 1,3 and $5 \mathrm{wt} . \%$ of the dry Nafion weight, were prepared.

Same method was followed to prepare pure DE2020 membranes, but this time no zeolite was added. Membranes were named as follows: DEZ X-Y, where DE, Z, X and Y stands for DE2020 Nafion, ZSM-5 zeolite, Si/Al ratio of the zeolite and the weight percentage of the zeolite, respectively (i.e. DEZ $75-3$ is DE2020 membrane containing $3 \mathrm{wt} . \%$ of ZSM-5 zeolite with the 75 $\mathrm{Si} / \mathrm{Al}$ ratio).

\subsection{Membrane characterization}

Scanning electron microscopy (SEM)

Membranes were visualized by a scanning electron microscope (Jeol JSM $5600 \mathrm{LV})$. The membrane samples were sputtered with a thin layer of gold (30 nm) using a Balzers Union SCD 040 sputtering device prior to the SEM observation.

Swelling degree (SD)

Membranes were dried in the vacuum oven at $30^{\circ} \mathrm{C}$ for 1 day and then immersed in ultra pure water. The weight of wet (Weightwet) and dry (Weightdry) samples were measured. The SD of the membrane was calculated using: 


$$
S D(\%)=\left(\frac{\text { Weight }_{\text {wet }}-\text { Weight }_{d r y}}{W e i g h t_{d r y}}\right) \cdot 100,
$$

Methanol permeability

The methanol permeability, $\mathrm{P}\left[\mathrm{cm}^{2} / \mathrm{s}\right]$, at $25^{\circ} \mathrm{C}$ was measured using a two compartment diffusion cell following the procedure described elsewhere [18].

\section{Proton conductivity}

Proton conductivity measurements were carried out at $25^{\circ} \mathrm{C}$ and $100 \%$ relative humidity, in cells with two-probe configuration following the procedure described elsewhere [22]. Prior to all experiments, membranes were equilibrated in ultra pure water for $24 \mathrm{~h}$.

\subsection{Fabrication of membrane-electrode assemblies}

E-TEK commercial electrodes were used to fabricate the membraneelectrode assemblies (MEAs). Both anode $(\mathrm{Pt}-\mathrm{Ru})$ and cathode $(\mathrm{Pt})$ contain $5 \mathrm{mg} / \mathrm{cm}^{2}$ of catalyst. The geometric area of each electrode was $6.25 \mathrm{~cm}^{2}$. The MEAs were prepared by hot pressing of the anode and cathode on both sides of the membrane at 10 bar for 5 minutes at $125^{\circ} \mathrm{C}$.

\subsection{Single cell DMFC performance}

The DMFC performance of the MEAs was evaluated following the procedure described elsewhere [18].

\section{Results and discussion}

\subsection{Characterization of the H-ZSM-5 zeolites}

As shown in Fig. 1, independent from the Al concentration in the mother sol, well crystallized seeds with XRD patterns consistent with the MFI reference, were obtained after only $1 \mathrm{~h}$ synthesis at $160^{\circ} \mathrm{C}$. 


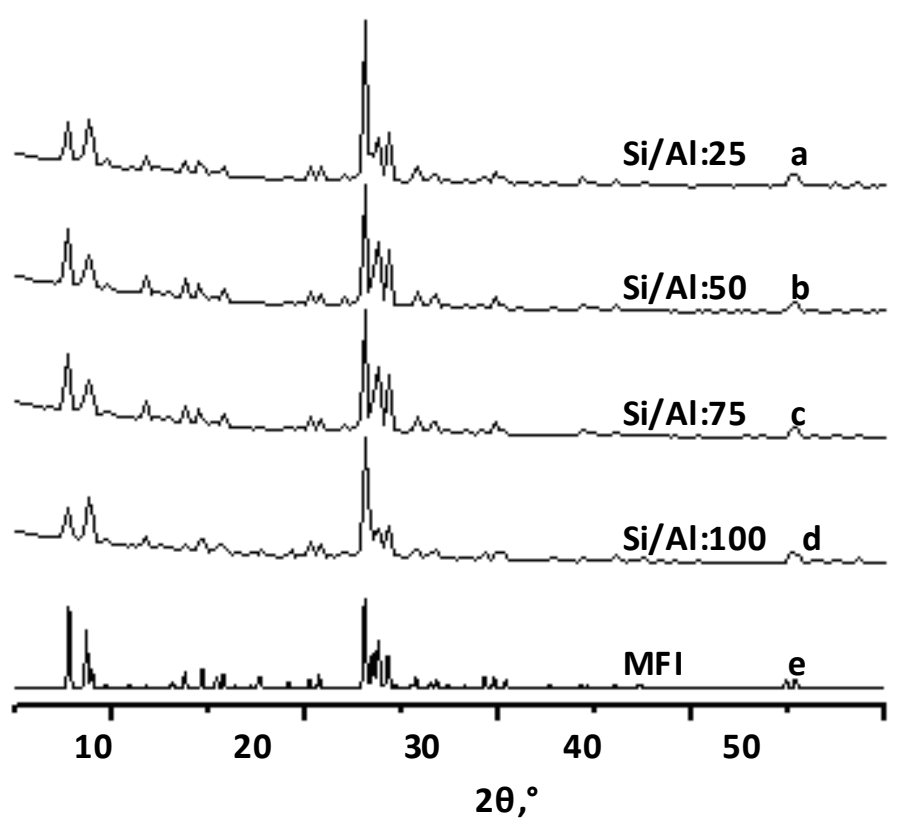

Figure 1. XRD patterns of the MW-derived ZSM- 5 crystals, prepared with different $\mathrm{Si} / \mathrm{Al}$ molar ratios: a) 25 , b) 50 , c) 75 , d) 100 . A MFI reference pattern is reported in e) for comparison.

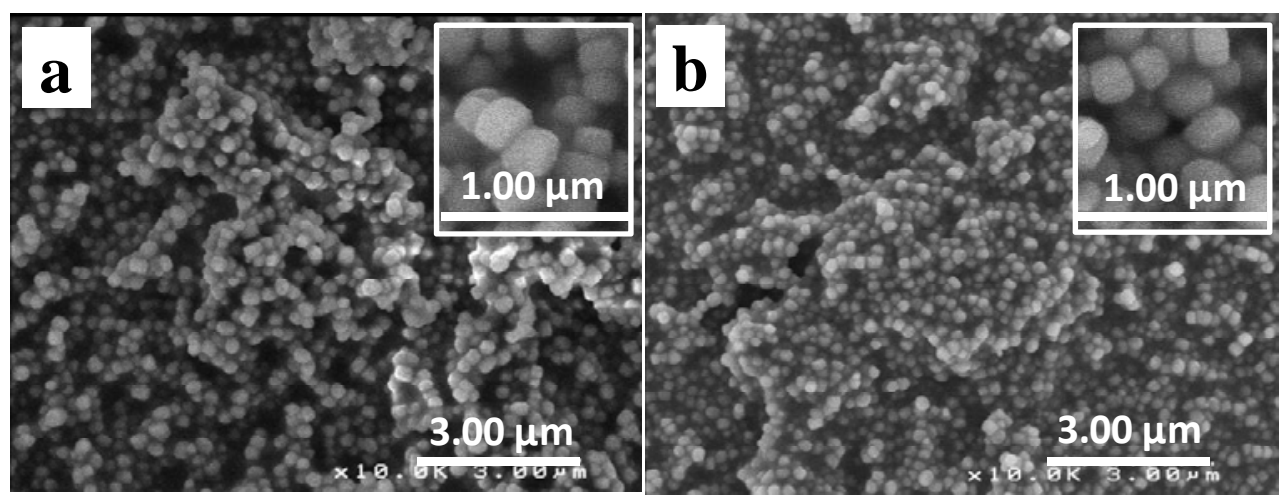

Figure 2. SEM observations of the ZSM-5 crystals prepared by a two steps MW- assisted hydrothermal synthesis method $\left(T_{1}=80^{\circ} \mathrm{C}, t_{1}=90 \mathrm{~min}, P_{1}=250 \mathrm{~W} ; T_{2}=160^{\circ} \mathrm{C}, t_{2}=60 \mathrm{~min}, P_{2}=400 \mathrm{~W}\right)$ using different $\mathrm{Si} / \mathrm{Al}$ molar ratios in the sol: a) 25 and b) 100.

Figure 2 shows SEM images of the seeds. Although generally sols with increasing $\mathrm{Al}$ concentrations tend to yield bigger seeds, in our case very similar crystal sizes (in the range of 200-300 nm) were obtained independent 
from the $\mathrm{Al}$ content in the mother sol. Consequently the influence of ZSM-5 seed size on the derived composite membrane performance will be neglected in comparison with the influence of crystal hydrophilicity which strongly increases with the $\mathrm{Al}$ concentration.

\subsection{SEM study of DE2020/ZSM-5 composite membranes}

Figure 3 shows typical SEM images of the surfaces and cross-section of DE2020 membrane and DEZ25-1 composite membrane. Top side of the composite membrane (facing the air) seems to be smoother and have more particles than the side facing the Teflon plate probably due to the difference in hydrophilicity of zeolites and Teflon. Besides, the zeolite particles might be dragged to the surface of the membrane during solvent evaporation.

Cross-sections of the composite membrane show that the distribution of the zeolite particles is good probably due to the ultrasonication during the membrane preparation. Pure DE2020 membrane has no zeolites in it and has clear surface and cross-section SEM images.

Figure 4 shows typical cross-section SEM images of the DEZ25-1, DEZ25-3 and DEZ25-5 composite membranes. Although aggregation might occur for DEZ25-5 membrane, the dispersion of the zeolite particles inside the membrane looks good. There is no visible accumulation of the zeolites towards any of the sides. Similar phenomena have been observed for the other composite membranes, as well.

Figure 5 shows typical cross-section SEM images of the composites with the highest zeolite loading (DEZ25-5, DEZ50-5, DEZ75-5 and DEZ100-5). All composite membranes have similar SEM images, no accumulation of the zeolites at the top or the bottom side of the membranes.

\subsection{Swelling experiments}

Figure 6 shows the swelling degrees of the membranes in ultra pure water. All composite membranes swell similar to DE2020 membrane. The difference in hydrophobicity of the zeolites (this increase in the order DEZ100>DEZ75>DEZ50>DEZ25) does not seem to have a significant effect on the membrane swelling in ultra pure water. 


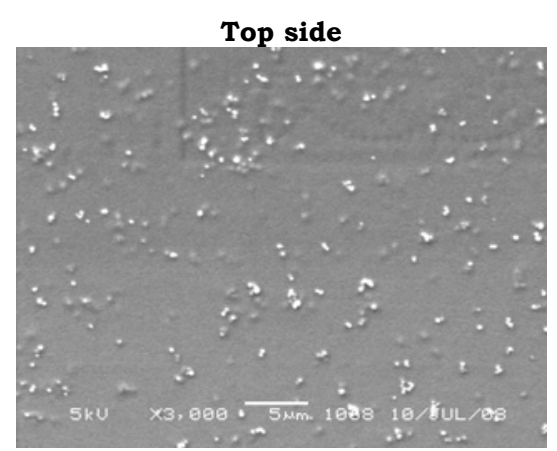

DEZ25-1
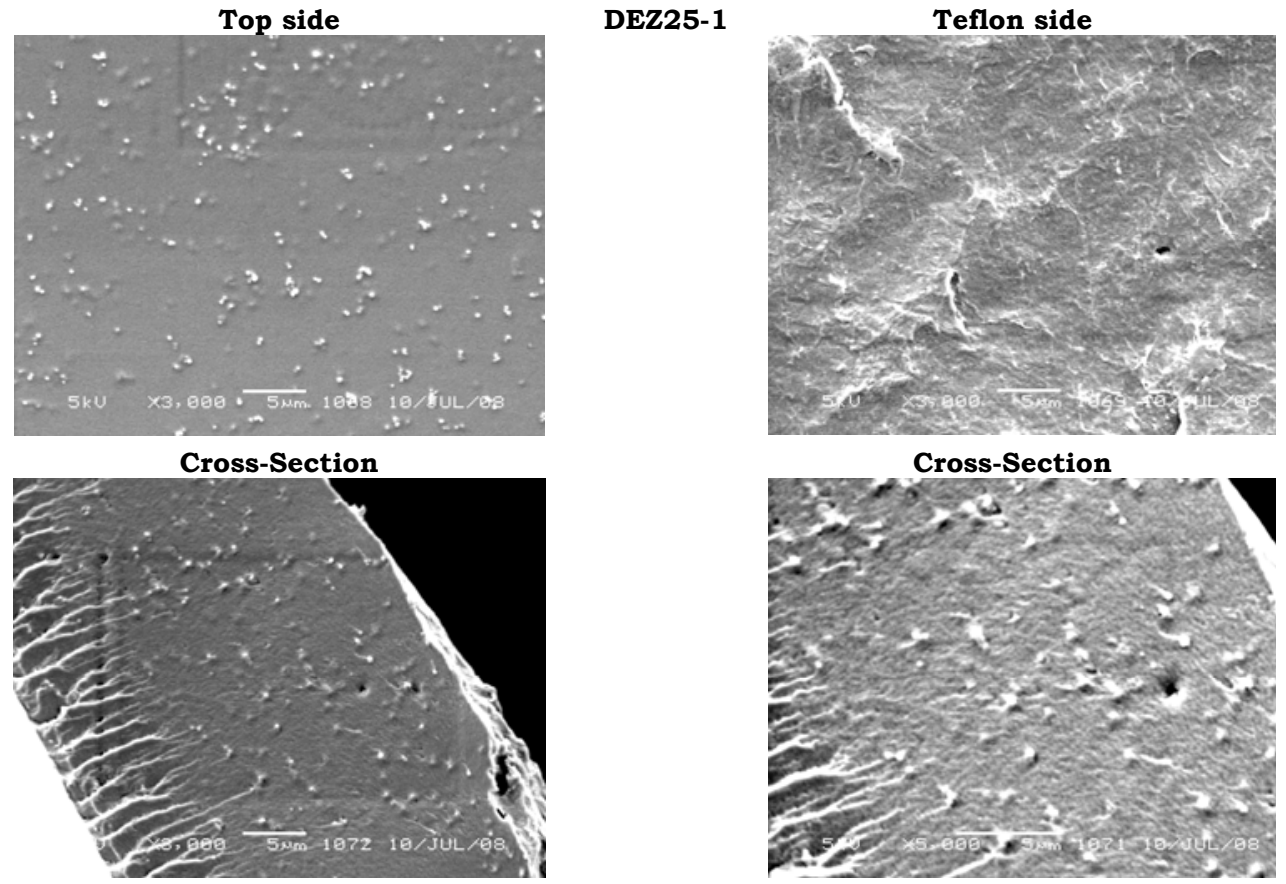

Top side

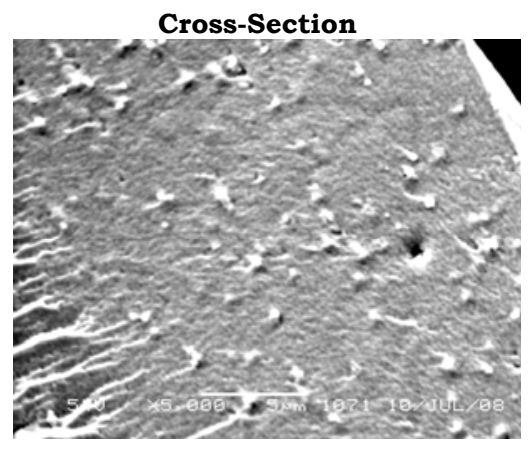

DE2020

Teflon side
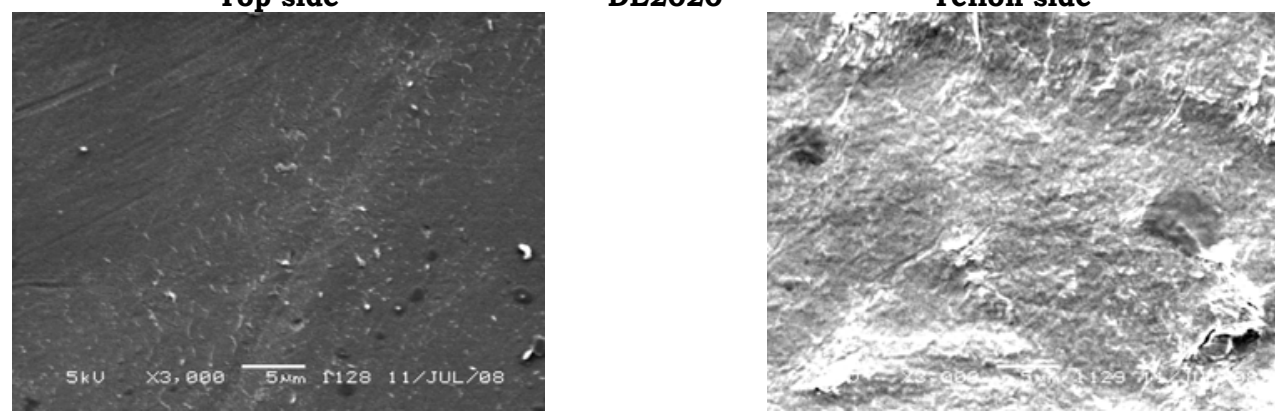

Cross-Section

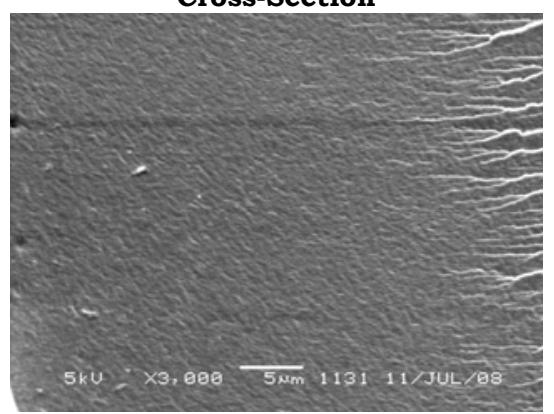

Cross-Section

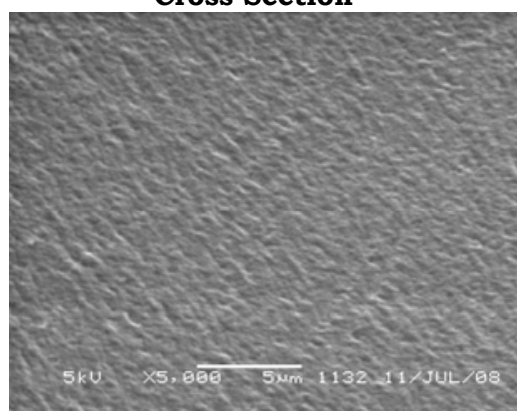

Figure 3. SEM images of the DEZ25-1 and DE2020 membranes. 
(a)
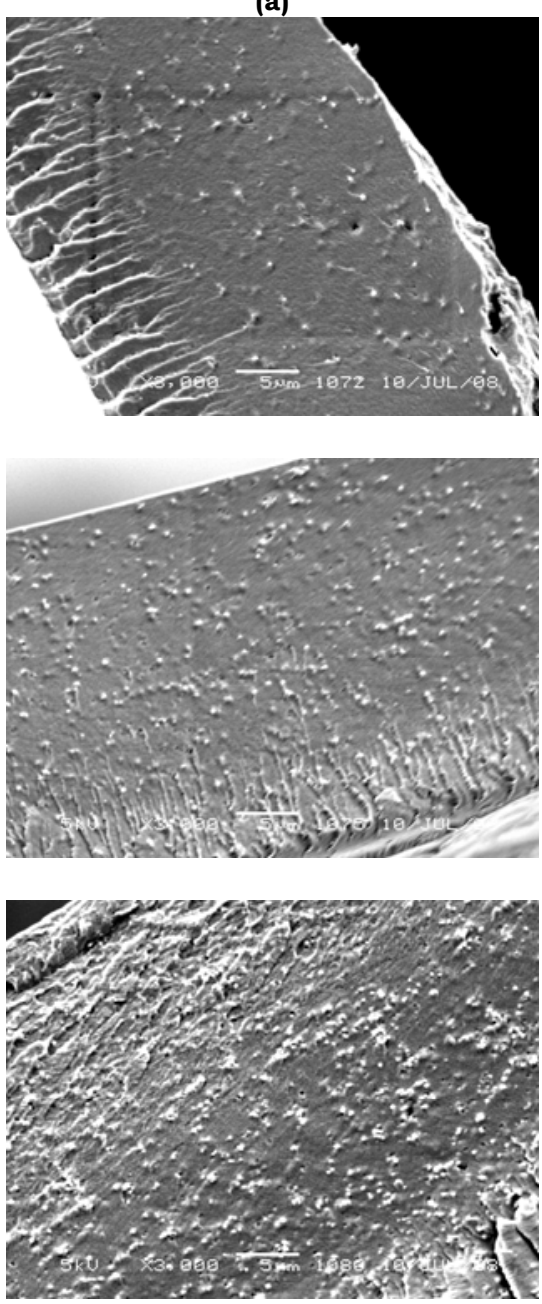

DEZ25-1

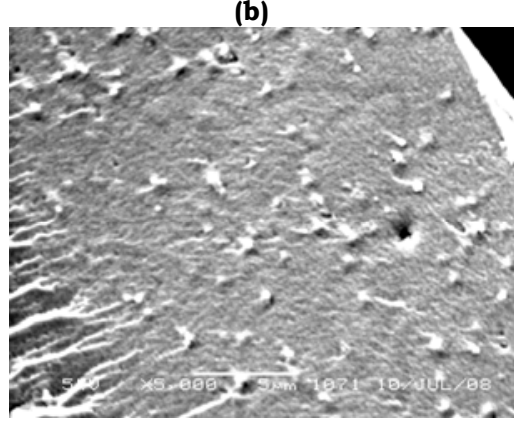

DEZ25-3

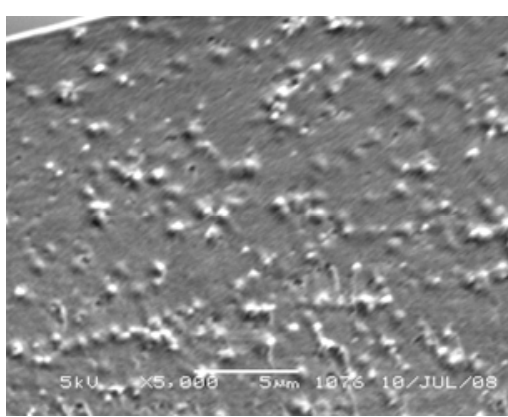

DEZ25-5

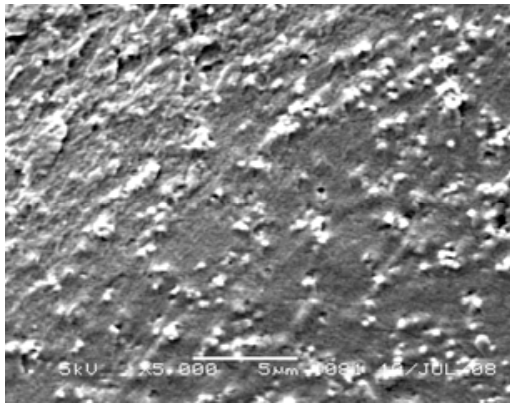

Figure 4. Cross-section SEM images of the DEZ25-1, DEZ25-3 and DEZ25-5 composite membranes. (a) magnification x3000 and (b) magnification x5000. 
(a)
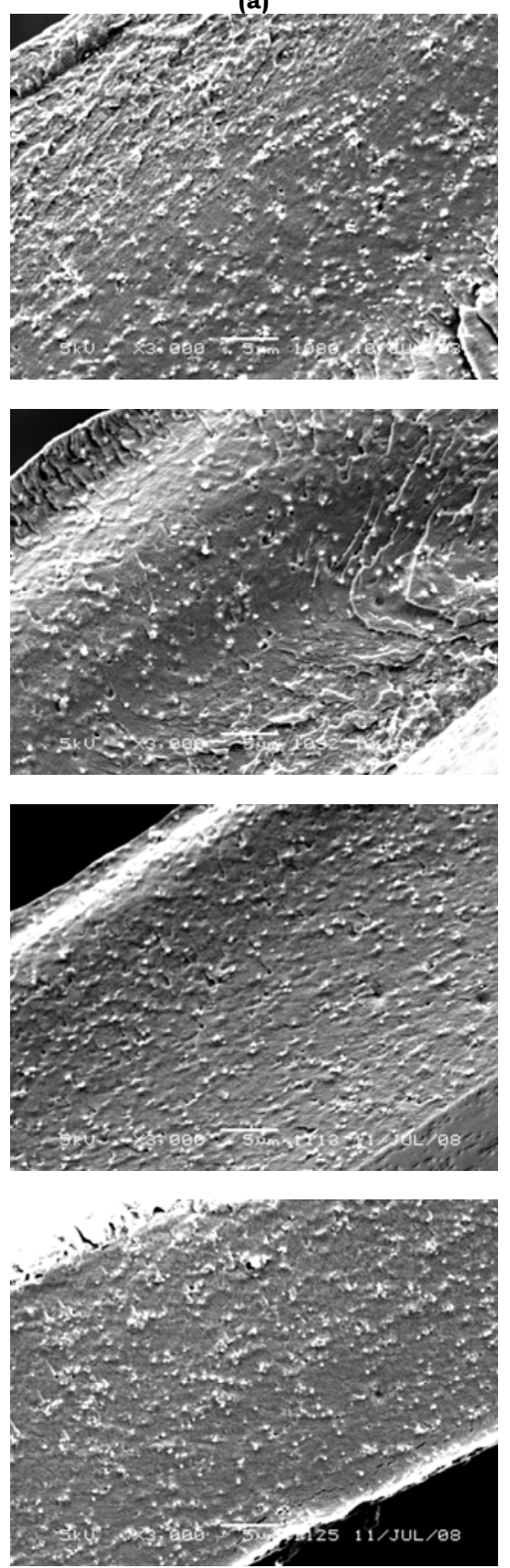

Figure 5. Cross-section SEM images of the DEZ25-5, DEZ50-5, DEZ75-5 and DEZ100-5 composite membranes. (a) Magnification x3000 and (b) Magnification x5000. (b)

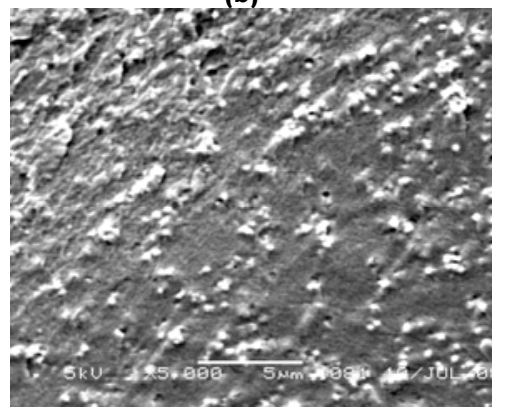

DEZ50-5

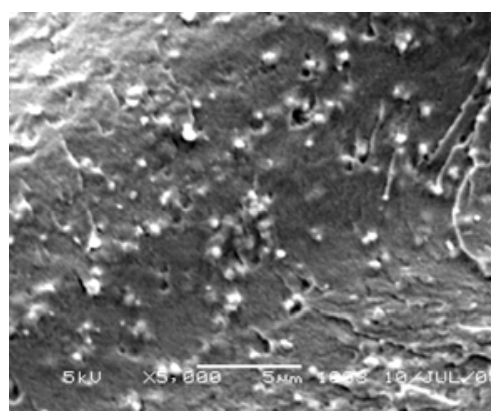

DEZ75-5

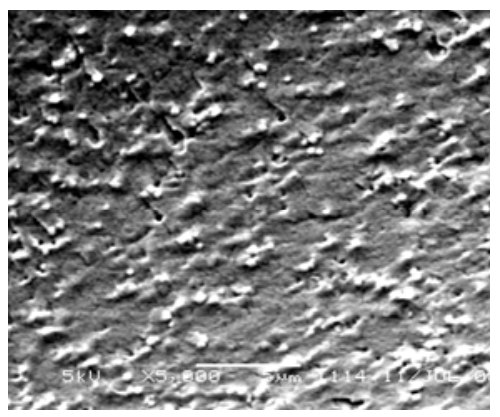

DEZ100-5

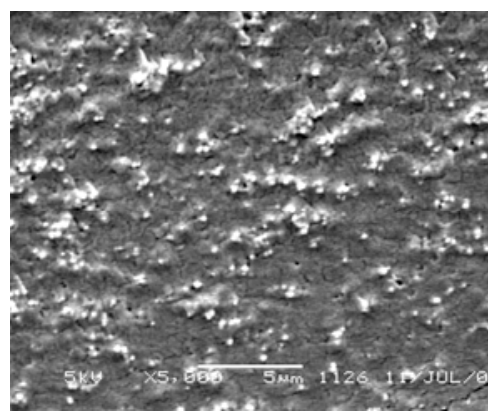




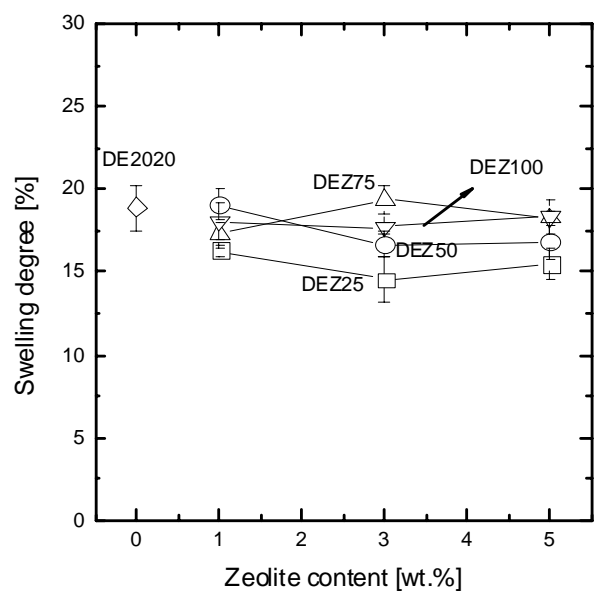

Figure 6. Swelling degrees of DE2020 and DEZ membranes as a function of zeolite content.

\subsection{Methanol permeability}

Figure $7 \mathrm{a}$ shows that the methanol permeabilities of the composite membranes are lower than pure DE2020 membrane, consistent with earlier study of Byun et al. [17] with Nafion/H-ZSM-5 composite membrane $(\mathrm{Si} / \mathrm{Al}=28)$. For most of the composite membranes, there is no effect of zeolite content or composition to the methanol cross-over. Interestingly, the methanol permeability of the DEZ25-5 is significantly lower than the others.

In the literature, Maxwell model is often used to describe transport properties in heterogeneous polymer systems. The simple form of Maxwell analyzes the steady-state dielectric properties of a dilute suspension of spheres where the permeability of a composite, $P$, made by dispersing of nonporous, impermeable filler in a continuous polymer matrix is expressed as

$$
P=P_{P} \cdot\left(\frac{1-\varphi_{f}}{1+\frac{\varphi_{f}}{2}}\right),
$$

where $P_{\mathrm{p}}$ is the permeability of the pure polymer and $\varphi_{f}$ is the volume fraction of filler. Eq. 2 suggests that the permeability of the filled polymer is lower than of the pure polymer and decreases with increasing of filler con- 
centration. The decreased permeability is the result of a reduction in penetrant solubility due to (i) the replacement of polymer through which transport may occur with filler particles and (ii) an increase in tortuosity of the diffusion path through which the penetrant molecules cross the polymeric film [23].
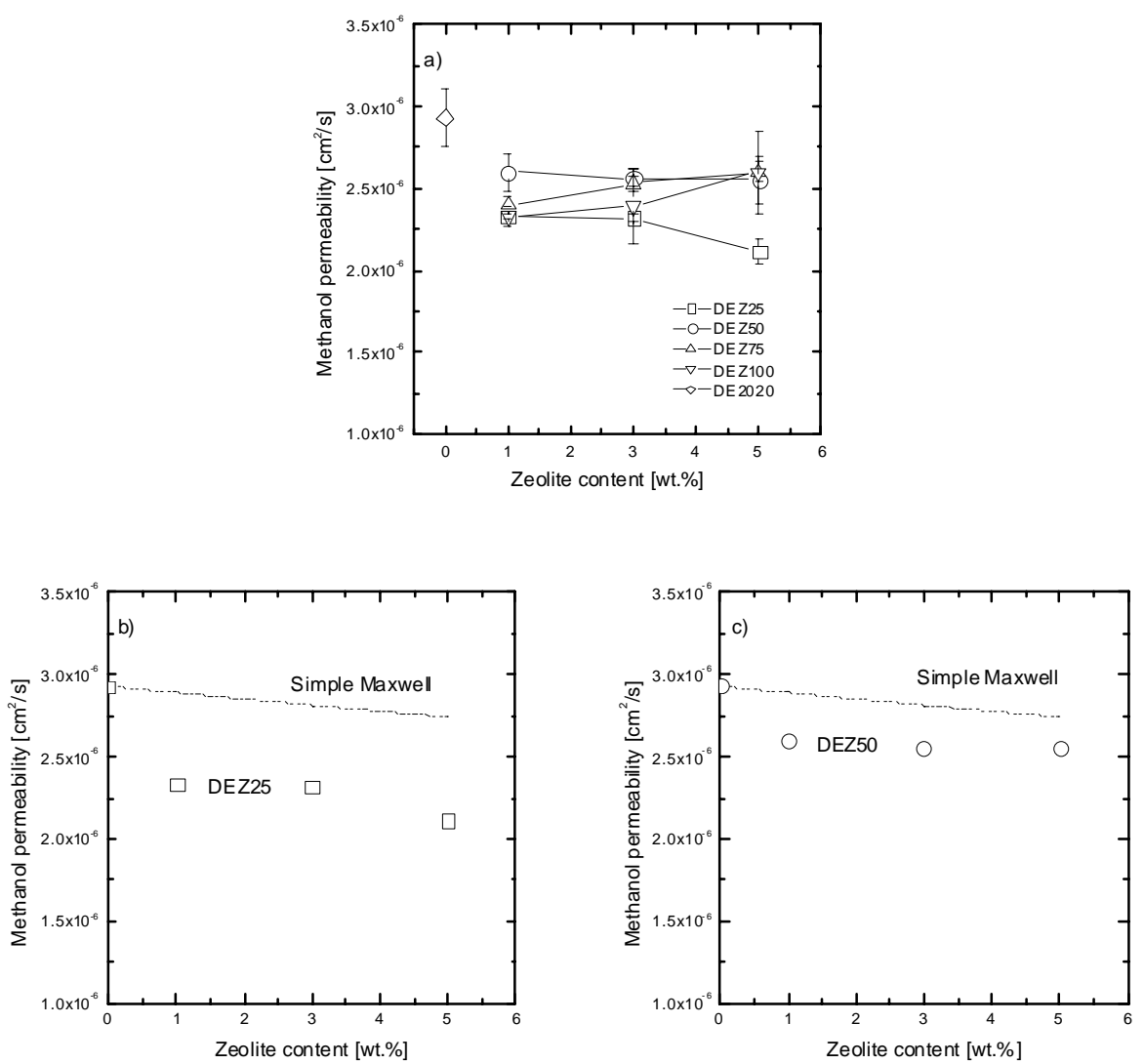

Figure 7. Methanol permeabilities of DE2020 and DEZ membranes as a function of zeolite content. The dashed line represents the prediction of simple Maxwell model.

Figure $7 \mathrm{~b}, 7 \mathrm{c}$ compares the experimental permeability results of two of the composite membranes (DEZ25 and DEZ50) with the theoretical prediction of a simple Maxwell model. The simple Maxwell model obviously fails to predict the experimental results, which are much lower than this predic- 
tion. Often aggregation of the particle, or phase separation occurs, causing significant change in the membrane morphology in comparison to pure polymer [23]. Besides, the morphology of the interface between the filler and polymer can be a critical determination of the overall transport properties [24]. Perhaps there is a rigidified polymer layer around the filler causing decrease in the permeability of the methanol through the composite membrane. The low cross-over of the DEZ25-5 membrane may be due to rigidification of the polymer around the particle in conjunction with particle aggregation.

\subsection{Proton conductivity}

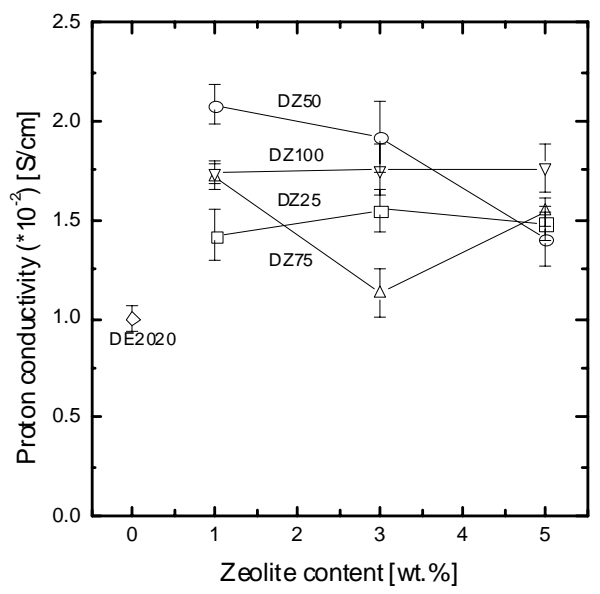

Figure 8. Proton conductivities of DE2020 and DEZ membranes as a function of zeolite content.

Figure 8 presents the proton conductivities of DE2020 and DEZ membranes as a function of zeolite content. Proton conductivities of all composite membranes are higher than the pure DE2020 membrane, consistent with earlier study [18]. DEZ50-1 shows the highest proton conductivity among the DEZ50 membranes while the conductivities of DEZ25 and DEZ100 do not change significantly with the zeolite content. On the other hand, the conductivity of DEZ75 somewhat scatters with zeolite content in the membrane. 


\subsection{Single cell performance}

In literature $[8,15-17]$ studies, which are dealing with polymer-zeolite composite membranes for DMFCs, use the characteristic number, $\beta$ (proton conductivity/methanol permeability), for prediction of DMFC performance instead of the real fuel cell. In this study, we combine the regular characterization methods with DMFC measurements. The DEZ25-5 and DEZ50-1 composite membranes were selected for further tests in DMFC due to their low methanol cross-over and high proton conductivity, respectively. Their performance is compared to that of pure DE2020. MEAs were prepared by hot pressing two E-TEK commercial electrodes on both sides of the membranes at 10bar. At least two MEAs were prepared and measured for each type of membrane. Every day minimum 20 polarization curves made for each MEA and then the system switched off and no methanol and oxygen fed to the system. The next day the system was switched on again and another 20 polarization curves were obtained. This procedure was followed for 5 days.

Figure 9 presents typical results of maximum power density of each polarization curve as a function of time for DE2020, DEZ50-1, DEZ25-5 and N117 membranes. The concentration of methanol at the anode side was $1 \mathrm{M}$. Each symbol in the graphs corresponds to a different MEA. All three composite membranes show an increase in their maximum power density (MPD) up to $400^{\text {th }}$ minute. It seems that in the beginning of the experiment, maximum power densities increase due to the activation of all catalyst particles and also due to wetting of the membrane. From that point on DE2020 shows an increase in its MPD in the beginning of the measurement and then decreases continuously till the end of the measurement for that Next day, it again shows high MPD value and then decreases again and if one waits long enough, MPD reaches around $275 \mathrm{~mW} / \mathrm{cm}^{2}$ (Figure 9a), which is in agreement with our previous study for DE2020 membrane [18]. DEZ50-1 shows similar phenomena, perhaps, due to its low zeolite loading. Its MPD reaches $250-275 \mathrm{~mW} / \mathrm{cm}^{2}$ (Figure 9b). The DEZ25-5 shows same trends (high MPD in the beginning and drop later) like the other two membranes. However, the drop is less sharp than the other two and most importantly reaches high MPD in the end of the $5^{\text {th }}$ day at around $300 \mathrm{~mW} / \mathrm{cm}^{2}$. One can see that the performance of N117 MEA (taken from our earlier work [18], prepared under the same conditions as DEZ MEAs) is very stable without drop throughout the day (Figure 9d). It seems that those fluctua- 
tions are characteristic of the specific DE2020 material and can be improved when significant amount (5wt.\%) of H-ZSM-5 is added.
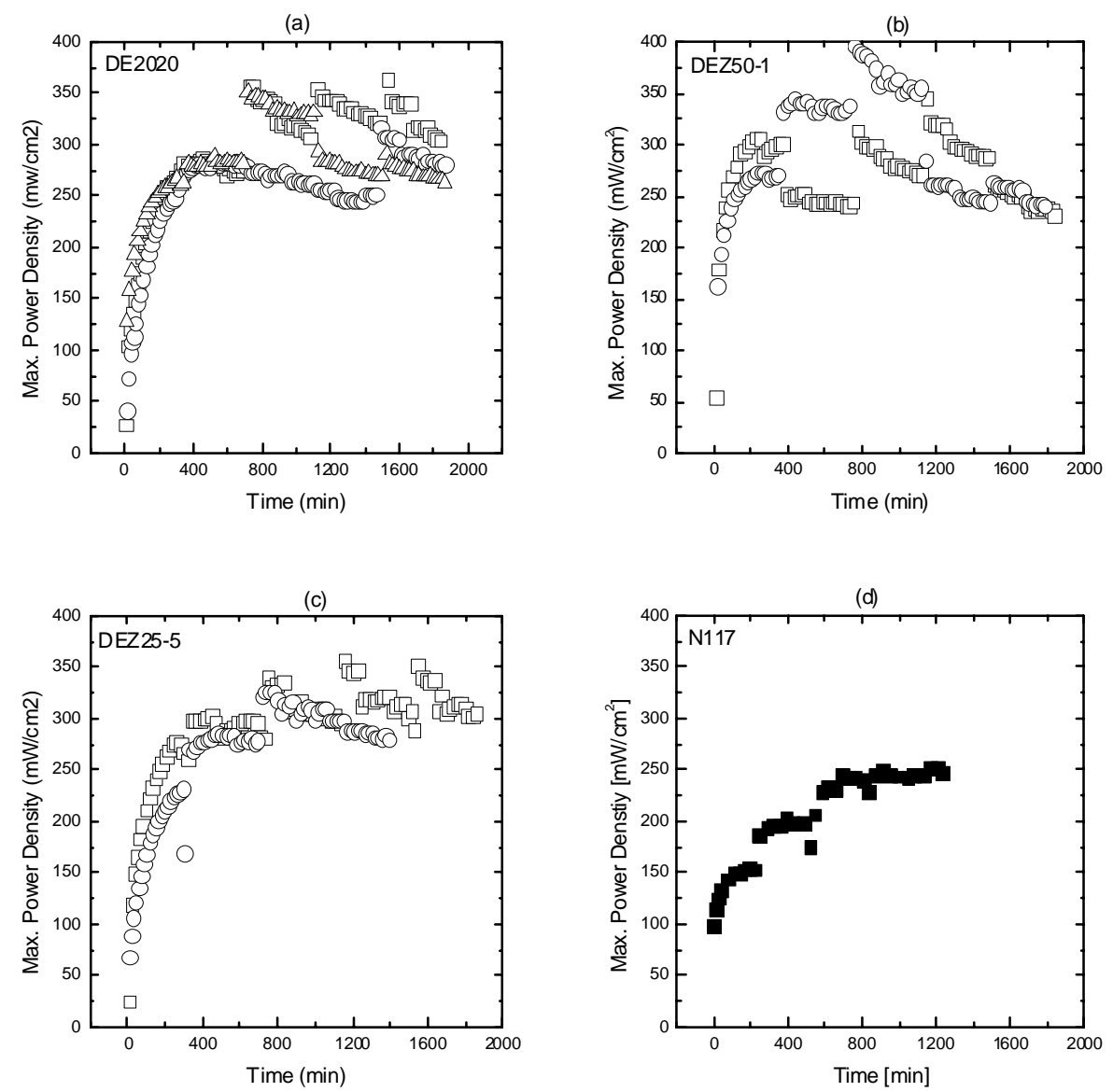

Figure 9. Maximum power densities of (a) DE2020, (b) DEZ50-1, (c) DEZ25-5 and (d) N117 membranes [18] as a function of time. The different symbols in each case correspond to a different MEA.

Figure 10 compares typical polarization and power density curves of the membranes in the end of the $5^{\text {th }}$ day. In the polarization curves, there are clear regions of activation, ohmic and concentration polarization. Open cell voltages of all membranes are in the same range and they are about $0.85 \mathrm{~V}$. The DEZ25-5 composite membrane with the lowest methanol crossover 
shows the best performance. This is shown clearly at the power density curves (Figure 10b). DEZ25-5 composite membrane shows better performance than DE2020 and DEZ50-1 membrane at low and high current density regions. Our results suggest that the methanol cross-over seems to be more critical and/or important to achieve better DMFC performance. This is consistent with our earlier work for Nafion-PE (N-PE) composite membrane [18]. N-PE with lower methanol cross-over than Nafion shows better DMFC performance than Nafion even though it has lower proton conductivity than Nafion.
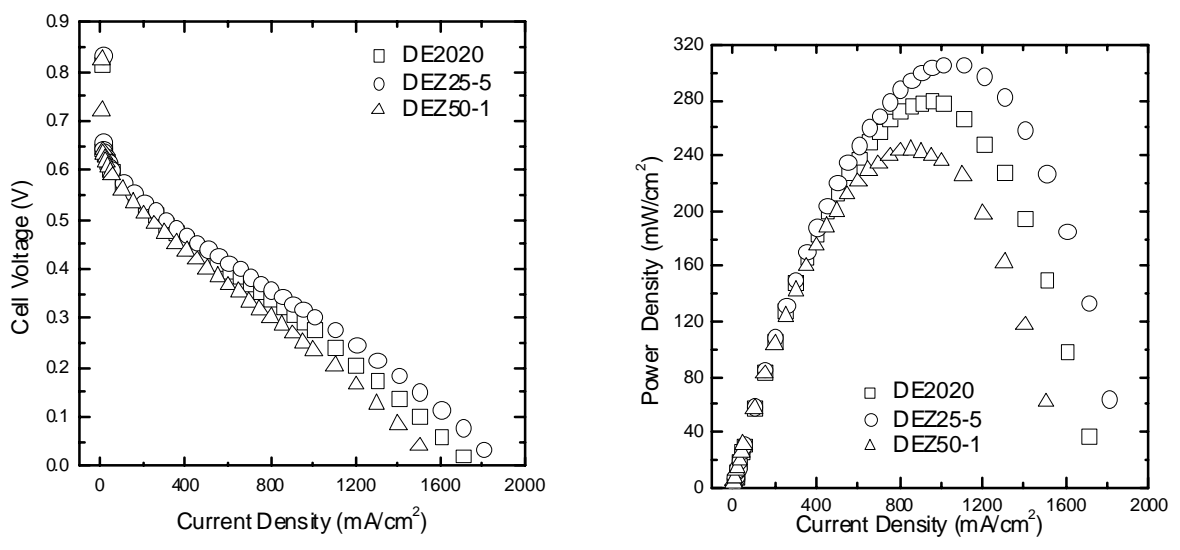

Figure 10. Typical (a) polarization and (b) power density curves of DE2020, DEZ50-1 and DEZ25-5 membranes on the $5^{\text {th }}$ measurement day in the DMFC.

\section{Conclusions}

In this study, composite membranes were prepared by mixing H-ZSM-5 zeolites with DE2020 dispersion and thoroughly characterized. All composite membranes have lower methanol permeabilities and higher proton conductivities than pure DE2020 membrane. Two of the membranes: DEZ25-5 and DEZ50-1 were further tested in DMFC due to their low methanol cross-over and high proton conductivity, respectively. The DEZ25-5 membrane showed the best DMFC results. Its maximum power density (MPD) was more stable throughout the measurements and it reached the highest MPD at the end of the $5^{\text {th }}$ day. 


\section{Acknowledgements}

This research was financially supported by the Dutch Technology Foundation STW (Project no: 5713). The authors wish to thank:

- Dr. Gijs Calis (DSM Solutech, The Netherlands), Dr. Bernd Bauer (FumaTech GmbH, Germany) and Dr. Ronald Mallant (ECN, The Netherlands) for discussions and suggestions concerning this work.

- Dr. Suzana Pereira Nunes and Dr. Mauricio Schieda, (Department of Membranes for Energy, GKSS Research Centre Geesthacht GmbH, Germany) for offering their proton conductivity set-up for our measurements.

\section{References}

1. Blum, A., Duvdevani, T., Philosoph, M., Rudoy, N., and Peled, E., Water-neutral micro direct-methanol fuel cell (DMFC) for portable applications. Journal of Power Sources, 2003. 117(1-2): p. 22.

2. Simoglou, A., Argyropoulos, P., Martin, E. B., Scott, K., Morris, A. J. and Taama, W. M., Dynamic modelling of the voltage response of direct methanol fuel cells and stacks Part I: Model development and validation. Chemical Engineering Science, 2001. 56(23): p. 6761.

3. Chen, C.Y. and Yang, P., Performance of an air-breathing direct methanol fuel cell. Journal of Power Sources, 2003. 123(1): p. 37.

4. Surampudi, S., Narayanan, S. R., Vamos, E., Frank, H., Halpert, G., LaConti, A., Kosek, J., Prakash, G. K. Surya, and Olah, G. A., Advances in direct oxidation methanol fuel cells. Journal of Power Sources, 1994. 47(3): p. 377.

5. Kelly, S.C., Deluga, G.A. and Smyrl, W.H., A Miniature Methanol/Air Polymer Electrolyte Fuel Cell. Electrochem. Solid-State Lett., 2000. 3: p. 407.

6. Bowen, T.C., Noble, R.D., and Falconer, J.L., Fundamentals and applications of pervaporation through zeolite membranes. Journal of Membrane Science, 2004. 245(1-2): p. 1.

7. Huang, Z., Guan, H.-m., Tan, W.1., Qiao, X.-Y., and Kulprathipanja, S., Pervaporation study of aqueous ethanol solution through zeoliteincorporated multilayer poly(vinyl alcohol) membranes: Effect of zeolites. Journal of Membrane Science, 2006. 276(1-2): p. 260. 
8. Libby, B., Smyrl, W.H., and Cussler, E.L., Polymer-Zeolite Composite Membranes for Direct Methanol Fuel Cells. AIChE Journal, 2003. 49(4): p. 991.

9. Berry, M.B., Libby, B.E., Rose, K., Haas, K.H., and Thompson, R.W., Incorporation of zeolites into composite matrices. Microporous and Mesoporous Materials, 2000. 39(1-2): p. 205.

10. Rieke, P.C. and Vanderborgh, N.E., Temperature dependence of water content and proton conductivity in polyperfluorosulfonic acid membranes. Journal of Membrane Science, 1987. 32(2-3): p. 313.

11. Scibona, G., Fabiani, C., and Scuppa, B., Electrochemical behaviour of nafion type membrane. Journal of Membrane Science, 1983. 16: p. 37.

12. Hsu, W.Y., Barkley, J.R., and Meakin, P., Ion Percolation and Insulator-to-Conductor Transition in Nafion Perfluorosulfonic Acid Membranes. Macromolecules, 1980. 13(1): p. 198-200.

13. Vanderborgh, N. and Nguyen, T.V., The rate of isothermal hydration of polyperfluorosulfonic acid membranes. J. Membr. Sci., 1998. 143: p. 235.

14. Yeager, H.L. and Yeo, R.S., Structural and transport properties of perfluorinated ion-exchange membrane. Mod. Aspects Electrochem., 1985. 16: p. 437.

15. Gribov, E.N., Parkhomchuk, E.V., Krivobokov, I.M., Darr, J.A., and Okunev, A.G., Supercritical $\mathrm{CO} 2$ assisted synthesis of highly selective nafion-zeolite nanocomposite membranes for direct methanol fuel cells. Journal of Membrane Science, 2007. 297(1-2):

16. Wang, J., Zheng, X., Wu, H., Zheng, B., Jiang, Z., Hao, X., and Wang, B., Effect of zeolites on chitosan/zeolite hybrid membranes for direct methanol fuel cell. Journal of Power Sources, 2008. 178(1): p. 9.

17. Byun, S.C., Jeong, Y.J., Park, J.W., Kim, S.D., Ha, H.Y., and Kim, W.J., Effect of solvent and crystal size on the selectivity of ZSM5/Nafion composite membranes fabricated by solution-casting method. Solid State Ionics, 2006. 177(37-38): p. 3233.

18. Yildirim, M.H., Stamatialis, D., and Wessling, M., Dimensionally stable Nafion-polyethylene composite membranes for direct metha- 
nol fuel cell applications. Journal of Membrane Science, 2008. $321(2)$ : p. 364.

19. Tantekin-Ersolmaz, S.B., Atalay-Oral, Ç., Tatller, M., ErdemSenatalar, A., Schoeman, B., and Sterte, J., Effect of zeolite particle size on the performance of polymer-zeolite mixed matrix membranes. Journal of Membrane Science, 2000. 175(2): p. 285.

20. Li, Q., Mihailova, B., Creaser, D., and Sterte, J., The nucleation period for crystallization of colloidal TPA-silicalite-1 with varying silica source. Microporous and Mesoporous Materials, 2000. 40(1-3): p. 53.

21. Motuzas, J., Julbe, A., Noble, R.D., Guizard, C., Beresnevicius, Z.J., and Cot, D., Rapid synthesis of silicalite-1 seeds by microwave assisted hydrothermal treatment. Microporous and Mesoporous Materials, 2005. 80(1-3): p. 73.

22. Gomes, D., Roeder, J., Ponce, M.L., and Nunes, S.P., Characterization of partially sulfonated polyoxadiazoles and oxadiazole-triazole copolymers. Journal of Membrane Science, 2007.

23. S95(1-2): p 121. Stamatialis, D.F., Mendes, E., Wubbenhorst, M., and Wessling, M., Fullerene-Modified Poly(2,6-dimethyl-1,4phenylene oxide) Gas Separation Membranes: Why Binding Is Better than Dispersing. Macromolecules, 2006. 39(26): p. 9234-9242.

24. Moore, T.T. and Koros, W.J., Non-ideal effects in organic-inorganic materials for gas separation membranes. Journal of Molecular Structure, 2005. 739(1-3): p. 87. 



\section{Chapter 5}

\section{Micro-structured Nafion membranes for DMFC applications}

M. Hakan Yildirim, J oost te Braake, H. Can Aran, Dimitris Stamatialis,

\section{Matthias Wessling}

\section{Abstract}

In this work, Nafion ${ }^{\circledR} 117$ (N117), heat and pressure treated (hp) N117 and micro-structured ( $\mu \mathrm{s})$ N117 membranes (prepared by hot embossing) are thoroughly characterized with respect to their swelling degree, methanol flux, membrane resistance and DMFC performance.

Heat and pressure treatment during hot embossing probably makes the membrane structure more compact. This inhibits infiltration of water and methanol into the hydrophobic polymer zones harder and leads to decrease in water content and methanol flux for the hp N117 and $\mu$ s N117 membranes. Nonetheless, all three membranes have similar resistances. The densification of the structure may facilitate transport of $\mathrm{H}^{+}$through the membrane due to decrease of tortuosity.

In the DMFC, the hp N117 has similar performance with normal N117 membrane despite its low methanol crossover. The $\mu \mathrm{s}$ N117, however, has better performance than normal N117 probably due to better catalyst utilization due to microstructure. In DMFC stacks, which contain multiple MEAs, this can lead to a higher power output gain and/or lower system volume. 


\section{Introduction}

Direct methanol fuel cells (DMFCs) are attracting an increasing interest because of the highly efficient power generation by using sustainable energy sources. DMFCs can be used mainly as power sources to portable electronic devices [1-5]. They have advantages over other battery technologies (e.g. lithium-ion batteries) for portable electronic devices where high power-toweight ratios, fast start up times and an easy-to-recharge character are needed $[6,7]$. However, DMFCs are still not commercially attractive because of the high catalyst loadings required and large system volumes.

One of the aspects which is often addressed in the literature to improve DMFC performance is the improvement of the polymer electrolyte membrane, itself. The Nafion ${ }^{\circledR}$ membrane which is currently being used broadly has excellent proton conductivity, mechanical strength and thermal and chemical stability but has rather high methanol crossover [8-12]. Researchers made already several attempts to improve the performance of Nafion membranes by impregnating them into porous supports [13-14] or by adding inorganic fillers to the polymer matrix [15-17].

Another aspect for improvement of fuel cell is better catalyst utilization by micro-structuring of the membrane surface. This interesting concept which has been applied for hydrogen fuel cells [7] and micro-DMFCs [18] (using nano-imprinted membranes) aims to achieve enhanced catalyst surface area without increase of geometric surface area of the membrane electrode assembly. In this work, we explore further the concept of micro-structuring Nafion membranes for DMFC at larger surface areas. We, in fact, investigate the effect of micro-structuring and heat and pressure treatment during hot embossing procedure on the overall DMFC performance of Nafion membranes. All membranes are characterized with respect to their swelling degree, methanol flux, membrane resistance and DMFC performance.

\section{Experimental}

\subsection{Materials}

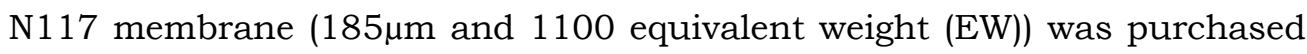
from Aldrich (Germany). E-TEK electrodes with standard $5.0 \mathrm{mg} / \mathrm{cm}^{2} \mathrm{TM}$ loading using unsupported HP Pt:Ru Alloy $(1: 1 \mathrm{a} / \mathrm{o})$ Black for the anode and $5.0 \mathrm{mg} / \mathrm{cm}^{2}$ Pt Black for the cathode were purchased from E-TEK DeNora (U.S.A.). 


\subsection{Preparation of micro-structured and heat/pressure treated Nafion membranes}

Hot embossing is a fast method for the replication of structures at the micro- and nano-scale. This technology, in principle, has the capability of patterning sub $10 \mathrm{~nm}$ features [19]. Identical structures can be produced as required over large surfaces. It is a simple, low cost process which creates patterns by mechanical deformation of imprint resist and subsequent processes. A schematic drawing of this process can be seen in Figure 1. Hot embossing can be used to pattern the membranes. A great variety of nanoscale features is possible, so different patterns can be made.

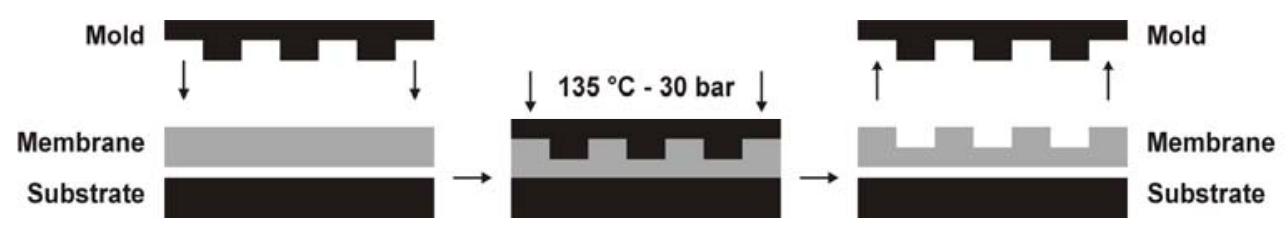

Figure 1. Hot embossing process.

In this work the membranes were patterned with hot embossing in a cleanroom. Prior to hot embossing, the membranes were kept in a vacuum oven at $30{ }^{\circ} \mathrm{C}$ for at least 24 hours. To distinguish the effect of heat and pressure alone during the hot embossing process, membranes were embossed using a non patterned mold so no structure was embossed onto the membrane, leaving it smooth. The membranes were hot embossed at a temperature of $135{ }^{\circ} \mathrm{C}$ for 6 minutes at pressure of 30 bars. After this, the membranes were cooled down under pressure to $60{ }^{\circ} \mathrm{C}$ in about 15 minutes and were easily peeled off from the mold.

\subsection{Membrane characterization}

Scanning electron microscopy (SEM)

Membranes were visualized by a scanning electron microscope (Jeol JSM $5600 \mathrm{LV})$. The membrane samples were sputtered with a thin layer of gold (30 nm) using a Balzers Union SCD 040 sputtering device prior to the SEM observation. 
Swelling degree (SD)

Membranes were dried in the vacuum oven at $30^{\circ} \mathrm{C}$ for 1 day and then immersed in ultra pure water. The weight of wet (Weightwet) and dry (Weightdry) samples were measured. The SD of the membrane was calculated using:

$$
S D(\%)=\left(\frac{\text { Weight }_{\text {wet }}-\text { Weight }_{d r y}}{W e i g h t_{d r y}}\right) \cdot 100,
$$

Methanol flux

Methanol flux, F $\left[\mathrm{mol} \cdot \mathrm{cm}^{-2} \cdot \mathrm{min}^{-1}\right]$, at $25^{\circ} \mathrm{C}$ was measured using a two compartment diffusion cell following the procedure described elsewhere [13].

\section{Membrane resistance}

Membrane resistance measurements were carried out at $25^{\circ} \mathrm{C}$ and $100 \%$ relative humidity, in cells with two-probe configuration following the procedure described elsewhere [20]. Prior to all experiments, membranes were equilibrated in ultra pure water for $24 \mathrm{~h}$.

\subsection{Fabrication of membrane-electrode assemblies}

E-TEK commercial electrodes were used to fabricate the membraneelectrode assemblies (MEAs). Both anode and cathode contain $5 \mathrm{mg} / \mathrm{cm}^{2} \mathrm{Pt}$ $\mathrm{Ru}$ and Pt, respectively. The geometric area of each electrode was $6.25 \mathrm{~cm}^{2}$. The MEAs were prepared by hot pressing of the anode and cathode on both sides of the membrane at 2 bars for 5 minutes at $125^{\circ} \mathrm{C}$. Comparing to our previous work [13], where MEAs were prepared at 10bar, the MEAs at this study were prepared at low pressure (2bar) to avoid damage at the microstructure during MEA preparation.

\subsection{Single cell DMFC performance}

The performance of the MEAs was evaluated following the procedure described elsewhere [13]. 


\section{Results and discussion}

3.1. SEM study of micro-structured Nafion composite membranes
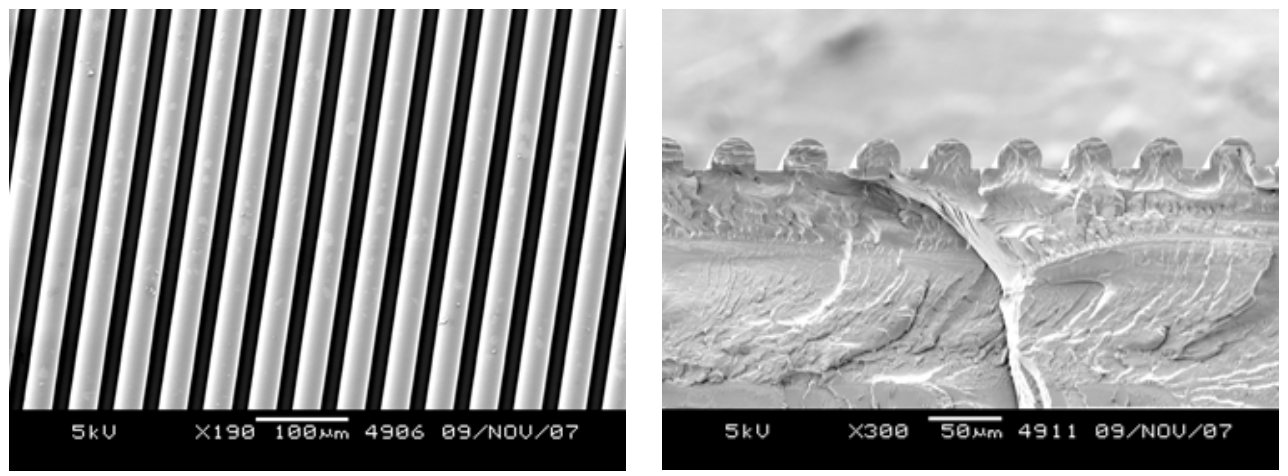

Figure 2. Surface and cross-section SEM images of the micro-structured Nafion membrane.

Figure 2 shows surface and cross-section SEM images of the microstructured Nafion membrane. Only one side of the membrane is hot embossed and the other side is flat. The dimensions of the structure were determined using the program SemAfore. The height of the channel structures is $20 \mu \mathrm{m}$, the width is $19 \mu \mathrm{m}$ and the distance between two features is $25 \mu \mathrm{m}$. Hot embossing the specific membrane should theoretically result in increased surface area of $45 \%$.

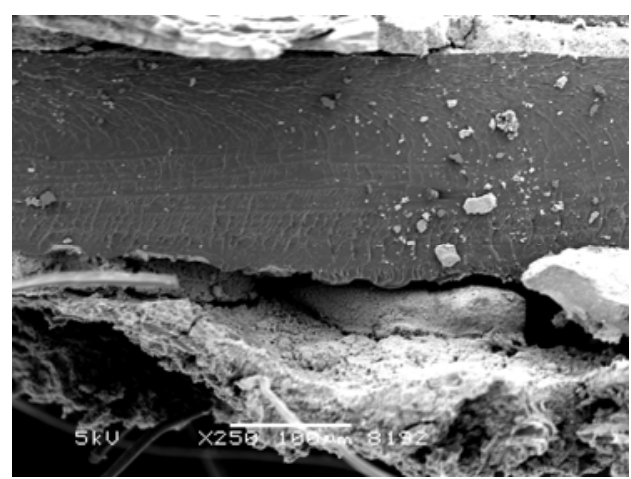

Figure 3. Cross section of the line structured Nafion ${ }^{\circledR} 117$ MEA.

Figure 3 shows the result after hot pressing $\left(125^{\circ} \mathrm{C}, 2\right.$ bars for 5 minutes $)$ the electrodes onto the channel structured membrane. The catalyst layer is 
adhering well to the non-structured side, whereas it is not always adjacent to the structured side of the membrane. It seems however that the structure could not be fully preserved after the MEA preparation procedure.

\subsection{Swelling experiments}

Figure 4 shows the results of the swelling experiments of as received, heat and pressure treated (hp) (hot embossed on a flat mold) and line structured ( $\mu$ s) N117 membranes. All values in Figure 4 are the average of three samples. After keeping the samples in ultra pure water, the swelling degree in weight for $\mathrm{Nafion}^{\circledR} 117$ is approximately $23 \%$, in agreement with our previous study [13]. However, the swelling of $\mu$ s N117 and hp N117 membranes is lower than the normal N117. This change in water uptake suggests that the membrane structure changed during hot embossing. Annealing at high temperature which causes rearrangements of the free volume in combination with the high pressure may caused compaction of the polymer network [21]. As a result, water may not be able to infiltrate into the hydrophobic zone resulting in decrease of swelling.

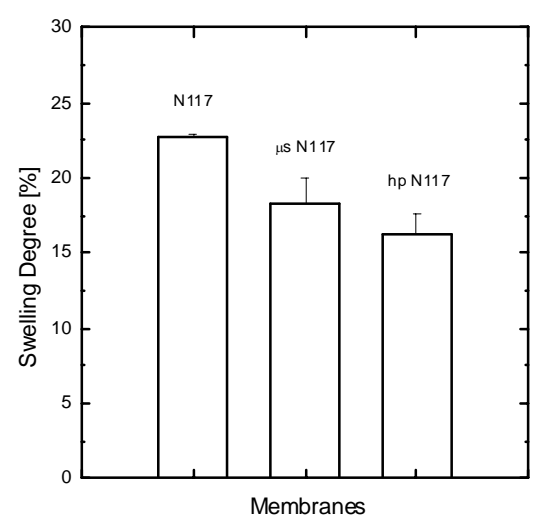

Figure 4. Swelling degrees of line structured ( $\mu \mathrm{s})$, heat and pressure treated $(\mathrm{hp})$ and as received N117 membranes.

\subsection{Methanol flux}

Figure $5 \mathrm{a}$ and $5 \mathrm{~b}$ show the methanol amount passing through the membranes in time and the methanol fluxes through line structured $(\mu \mathrm{s})$, 
heat and pressure treated (hp) and normal N117 membranes, respectively. The methanol fluxes in Figure $5 \mathrm{~b}$ are calculated from the slope of the graphs in Figure $5 \mathrm{a}$ divided by the geometric surface area of the membranes. The hp N117 (non structured) membrane has much lower flux than the normal N117 membrane although both membranes have the same geometric surface area. This decrease may be due to changes in membrane structure (compaction) as explained in the section of swelling. Interestingly, the $\mu \mathrm{s}$ N117 and hp N117 membranes have similar methanol transport (Figure 5a). Although one would expect higher methanol transport through the $\mu$ s N117 due to the increased micro-structured surface area. Perhaps, due to swelling in methanol, the microstructure is partly lost or the effect of the microstructure on the methanol flux is rather small and basically masked by the strong effect of the heat and pressure treatment.
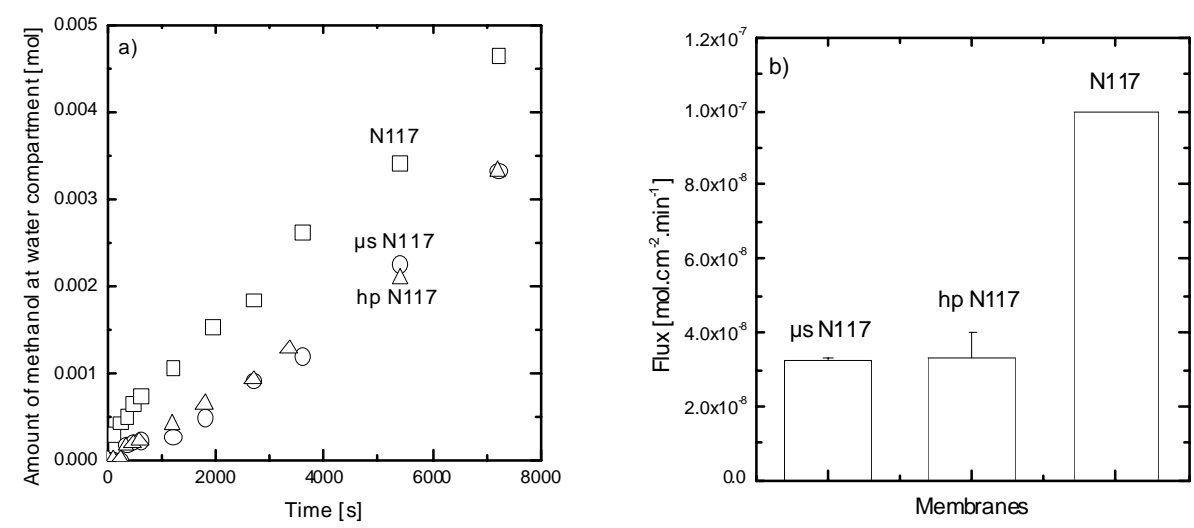

Figure 5. a) Methanol amount passing through the membrane and b) methanol fluxes of line structured ( $\mu \mathrm{s})$, heat and pressure treated (hp) and normal N117 membranes.

\subsection{Membrane resistance}

Figure 6 presents the resistances of $\mu$ s N117, hp N117 and normal N117 membranes. Unlike methanol flux, the heat and pressure treatment doesn't have any effect on membrane resistance. All three membranes have similar resistances. In the literature there are few articles discussing the effect of heat treatment to the $\mathrm{Nafion}^{\circledR}$ resistance with rather conflicting messages. Sone et al. for example reported that heat treatment of $\mathrm{Nafion}^{\circledR}$ increases 
membrane resistance due to a change in structure [22]. According to them, the heat treatment creates smaller ionic clusters, smaller pores and longer or tortuous transport channels. All these factors can cause increase in resistance. Liang et al. however, found an increase in concentration of sulfonic acid groups at the surface of a Nafion ${ }^{\circledR} 115$ membrane after heat treatment [23]. According to them, the heat treatment (150-230 ${ }^{\circ} \mathrm{C}$ for 1,5 hours) sets free sulfonic groups that were previously buried in the backbone and side chains forming more compact clusters [21]. A high concentration of sulfonic acid groups near the surface decreases the contact resistance between membrane and impedance measuring electrodes causing the conductivity to approach that of the actual bulk conductivity [24]. Concerning our membranes, on first site one would expect increase of membrane resistance due to the densification of the structure and lower amount of water adsorbed by the membrane (see earlier section). Nonetheless, the densification itself may also increase the transport of $\mathrm{H}^{+}$through the membrane due to decrease of tortuosity. The overall observed resistances (Fig. 6) may be result of counterbalancing of these two mechanisms.

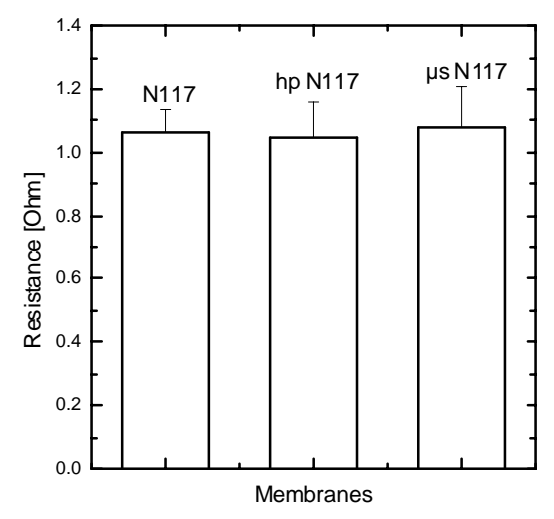

Figure 6. Resistances of line structured ( $\mu \mathrm{s})$, heat and pressure treated (hp) and normal N117 membranes.

\subsection{Single cell performance}

Figure 7 shows maximum power density values of $\mu$ s N117, hp N117 and normal N117 membranes as a function of time. MEAs were prepared using 
2 bars of pressure in order to preserve the micro-structures on the membrane. Each symbol in the graph corresponds to a different membrane. Plotted values were the average of minimum 2 measurements. For all membranes, the maximum power density increases in time during the first day due to the activation of the catalyst particles and the membrane and later reaches a plateau, in agreement with our previous study [13]. The power densities of $\mu \mathrm{s} \mathrm{N} 117$, hp N117 and normal N117 membranes, after 800min of operation, are $230 \pm 14 \mathrm{~mW} / \mathrm{cm}^{2}, 215 \pm 7 \mathrm{~mW} / \mathrm{cm}^{2}$ and $205 \pm 7$ $\mathrm{mW} / \mathrm{cm}^{2}$, respectively.

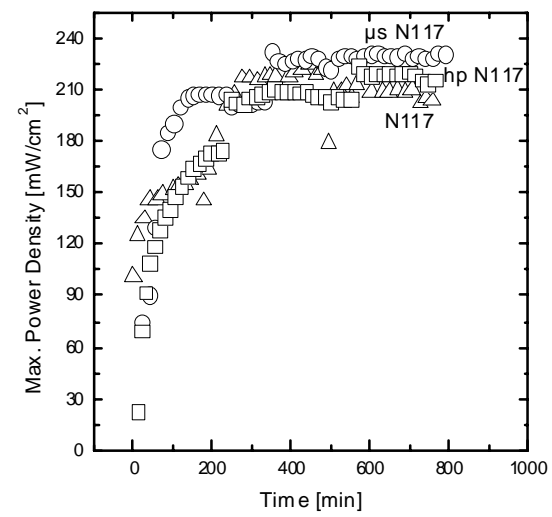

Figure 7. Maximum power density values of various N117 membranes as a function of measurement time.

Figure 8 shows the polarization and power density curves of each membrane at the end of the last measurement day. The hp N117 and $\mu \mathrm{s}$ N117 have higher open cell voltages than the normal N117 membrane due to their low methanol fluxes. Power densities of all membranes are similar at current densities below $600 \mathrm{~mA} / \mathrm{cm}^{2}$. When the current density increases further, then the performance of membranes differs from one another. In fact, the performance of $\mu$ s N117 membrane is better than both hp N117 and normal N117 membrane probably due to better electrocatalyst utilization due to increased effective surface area. However, the performance of hp N117 is not significantly better than normal N117 membrane despite its low methanol crossover. 
In conclusion, it seems that the $\mu$ s N117 is better than hp N117 and N117 due to better catalyst utilization. In DMFC stacks, which contain multiple MEAs, this improvement can lead to a higher power output gain and/or lower system volume. It is finally important to note that besides $\mu$ s N117 with lined microstructure, we also prepared squared micro-structured membranes by embossing the line structure on the membrane twice; once normal and once in $90^{\circ}$ to the previous. The power density of this microstructured membrane was also around $230 \mathrm{~mW} / \mathrm{cm}^{2}$; very similar to that of line structured one. We think that more work needs to be done to obtain even better DMFC performance. The preparation of MEA without damaging the microstructure of the membrane and one of the critical issues to be resolved.
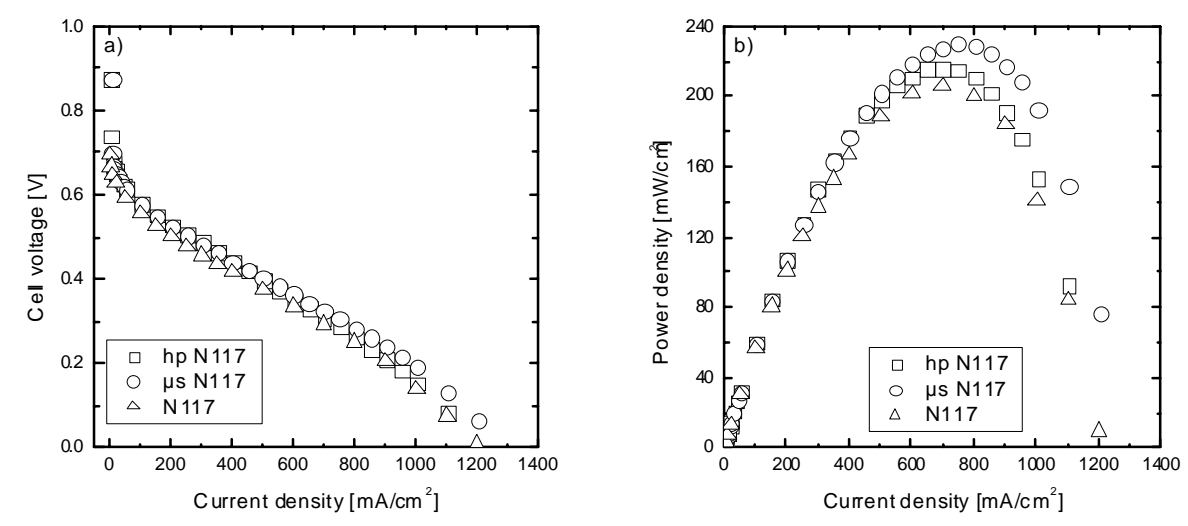

Figure 8 (a) Polarization and (b)power density curves of line structured ( $\mu \mathrm{s})$, heat and pressure treated (hp) and normal N117 membranes.

\section{Conclusions}

In the present work, $\mathrm{N} 117, \mathrm{hp} \mathrm{N} 117$ and $\mu \mathrm{s}$ N117 membranes were prepared and characterized to understand the effect of heat and pressure treatment and also the micro-structuring on the overall membrane performance.

Methanol fluxes through hp N117 and $\mu$ s N117 membranes are factor of 3 lower than normal N117 membrane probably due to compaction of membrane structure leading to decrease in water content and methanol flux of 
hp N117 and $\mu$ s N117 membranes. However, the membrane resistances of all three membranes were similar.

In the DMFC, $\mu$ s N117 performed the best and reached higher power densities than hp N117 and normal N117 membranes.

\section{Acknowledgements}

This research was financially supported by the Dutch Technology Foundation STW (Project no: 5713). The authors wish to thank:

- Dr. Ronald Mallant (ECN, The Netherlands), Dr. Bernd Bauer (FumaTech GmbH, Germany) and Dr. Gijs Calis (DSM Solutech, The Netherlands) for discussions and suggestions concerning this work.

- Dr. Suzana Pereira Nunes and Dr. Mauricio Schieda, (Department of Membranes for Energy, GKSS Research Centre Geesthacht GmbH, Germany) for offering their proton conductivity set-up for our measurements.

\section{References}

1. Surampudi, S., Narayanan, S. R., Vamos, E., Frank, H., Halpert, G., LaConti, A., Kosek, J., Prakash, G. K. Surya, and Olah, G. A., Advances in direct oxidation methanol fuel cells. Journal of Power Sources, 1994. 47(3): p. 377.

2. Chen, C.Y. and Yang, P., Performance of an air-breathing direct methanol fuel cell. Journal of Power Sources, 2003. 123(1): p. 37.

3. Simoglou, A., Argyropoulos, P., Martin, E. B., Scott, K., Morris, A. J. and Taama, W. M., Dynamic modelling of the voltage response of direct methanol fuel cells and stacks Part I: Model development and validation. Chemical Engineering Science, 2001. 56(23): p. 6761.

4. Kelly, S.C., Deluga, G.A. and Smyrl, W.H., A Miniature Methanol/Air Polymer Electrolyte Fuel Cell. Electrochem. Solid-State Lett., 2000. 3: p. 407.

5. Blum, A., Duvdevani, T., Philosoph, M., Rudoy, N., and Peled, E., Water-neutral micro direct-methanol fuel cell (DMFC) for portable applications. Journal of Power Sources, 2003. 117(1-2): p. 22. 
6. Taylor, A.D., Lucas, B.D., Guo, L.J., and Thompson, L.T., Nanoimprinted electrodes for micro-fuel cell applications. Journal of Power Sources, 2007. 171(1): p. 218.

7. Zhou, Z., Dominey, R.N., Rolland, J.P., Maynor, B.W., Pandya, A.A., and DeSimone, J.M., Molded, high surface area polymer electrolyte membranes from cured liquid precursors. Journal of the American Chemical Society, 2006. 128(39): p. 12963.

8. Rieke, P.C. and Vanderborgh, N.E., Temperature dependence of water content and proton conductivity in polyperfluorosulfonic acid membranes. Journal of Membrane Science, 1987. 32(2-3): p. 313.

9. Scibona, G., Fabiani, C., and Scuppa, B., Electrochemical behaviour of nafion type membrane. Journal of Membrane Science, 1983. 16: p. 37.

10. Hsu, W.Y., Barkley, J.R., and Meakin, P., Ion Percolation and Insulator-to-Conductor Transition in Nafion Perfluorosulfonic Acid Membranes. Macromolecules, 1980. 13(1): p. 198-200.

11. Vanderborgh, N. and Nguyen, T.V., The rate of isothermal hydration of polyperfluorosulfonic acid membranes. J. Membr. Sci., 1998. 143: p. 235.

12. Yeager, H.L. and Yeo, R.S., Structural and transport properties of perfluorinated ion-exchange membrane. Mod. Aspects Electrochem., 1985. 16: p. 437.

13. Yildirim, M.H., Stamatialis, D., and Wessling, M., Dimensionally stable Nafion-polyethylene composite membranes for direct methanol fuel cell applications. Journal of Membrane Science, 2008. $321(2):$ p. 364.

14. Lin, H.-L., Yu, T.L., Huang, L.-N., Chen, L.-C., Shen, K.-S., and Jung, G.-B., Nafion/PTFE composite membranes for direct methanol fuel cell applications. Journal of Power Sources, 2005. 150: p. 11.

15. Gribov, E.N., Parkhomchuk, E.V., Krivobokov, I.M., Darr, J.A., and Okunev, A.G., Supercritical $\mathrm{CO} 2$ assisted synthesis of highly selective nafion-zeolite nanocomposite membranes for direct methanol fuel cells. Journal of Membrane Science, 2007. 297(1-2):

16. Wang, J., Zheng, X., Wu, H., Zheng, B., Jiang, Z., Hao, X., and Wang, B., Effect of zeolites on chitosan/zeolite hybrid membranes 
for direct methanol fuel cell. Journal of Power Sources, 2008. 178(1): p. 9.

17. Byun, S.C., Jeong, Y.J., Park, J.W., Kim, S.D., Ha, H.Y., and Kim, W.J., Effect of solvent and crystal size on the selectivity of ZSM5/Nafion composite membranes fabricated by solution-casting method. Solid State Ionics, 2006. 177(37-38): p. 3233.

18. Zhang, Y., Lu, J., Shimano, S., Zhou, H., and Maeda, R., Development of MEMS-based direct methanol fuel cell with high power density using nanoimprint technology. Electrochemistry Communications, 2007. 9(6): p. 1365.

19. Guo, L.J., Recent progress in nanoimprint technology and its applications. Journal of Physics D: Applied Physics, 2004. 37(11): p. R123.

20. Gomes, D., Roeder, J., Ponce, M.L., and Nunes, S.P., Characterization of partially sulfonated polyoxadiazoles and oxadiazole-triazole copolymers. Journal of Membrane Science, 2007.

21. 295(1-2): Puan, Phang, Y., Zhang, H., Li, L., Li, H., and Liu, Y., Annealing effect of perfluorosulfonated ionomer membranes on proton conductivity and methanol permeability. Journal of Applied Polymer Science, 2008. 107(1): p. 396.

22. Sone, Y., Ekdunge, P., and Simonsson, D., Proton Conductivily of Nafion 117 as Measured by a Four-Electrode AC Impedance Method. Journal Electrochemical Soc., 1996. 143(4): p. 1254-1259.

23. Liang, Z., W.Chen, J.Liu, S.Wang, Z.Zhou, W.Li, G.Sun, and Q.Xin, FT-IR study of the microstructure of Nafion membrane. Journal of Membrane Science, 2004. 233(39).

24. J.E.Hensley, J.D.Way, S.F.Dec, and K.D.Abney, The effects of thermal annealing on commercial Nafion membranes. Journal of Membrane Science, 2007. 298: p. 190-201. 


\section{Chapter 6 \\ Reflections and outlook}

This thesis dealt with the development of new membrane materials for DMFCs. New membrane materials were prepared by impregnating ionomers into porous substrates (Chapter 2-3), adding zeolites into the bulk phase of the polymer (Chapter 4) and micro-structuring the surface of the polymer with hot embossing technique (Chapter 5) in order to achieve the ultimate goal of the project: membranes with low methanol cross-over, high proton conductivity and high DMFC performance.

In Chapter $\mathbf{2}$ and Chapter 3, impregnated membranes were tested for DMFC applications. In Chapter 2 a product of DSM Solutech (The Netherlands) was used and in Chapter 3 impregnation was done in house to prepare the composite membranes. In both cases the porous substrate was PE (Solupor ${ }^{\circledR}$ ) from DSM Solutech. The results of both chapters clearly showed that impregnating these polymers into the porous substrate increases their dimensional stability, decreases water content and methanol cross-over resulting into higher DMFC performance in comparison to the free standing polymer.

(a)

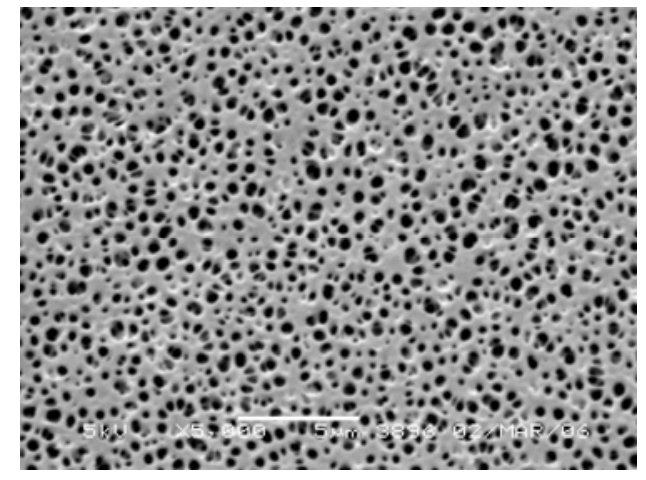

(b)

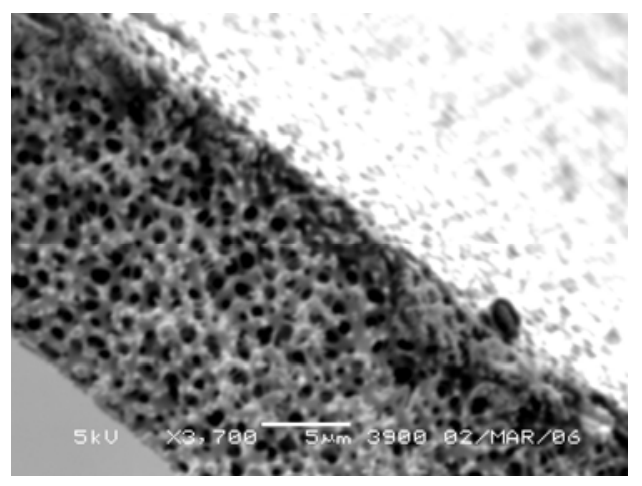

Figure 1. (a) Surface and (b) cross-section SEM images of PEI membranes.

Besides, PE material, which was provided by DSM Solutech, we also prepared our own substrates using poly(ether imide) (PEI) for impregnation of 
fluorocarbon and hydrocarbon materials. PEI membranes with different pore sizes ranging from $1 \mu \mathrm{m}$ to $10 \mu \mathrm{m}$ were prepared. Figure 1 shows the surface and cross-section SEM images of PEI substrates.

Different methods were tried to impregnate the polymer solutions into the pores of the PEI film i.e, brushing, dipping and casting solution layers on both sides of the substrate. None of these methods gave a fully impregnated membrane. The PEI material was very porous and too open to impregnate. Membranes with smaller pore size maybe better for impregnation. Besides, increase of affinity of the material and of impregnated polymer solution [1] and/or multiple impregnations, using surfactants in the impregnation polymer solution to increase the possibility of impregnation level can be used.

In Chapter 4, composite membranes were prepared by mixing H-ZSM-5 zeolites with DE2020 dispersion. This study showed that composite membranes have indeed lower methanol permeability and higher proton conductivity than pure DE2020 membrane. DEZ25-5 has the best performance namely high power density and stable performance in time with low fluctuations. This is, in fact, the membrane with the best DMFC performance in this thesis.

For further improvement of performance of these composite membranes, several new strategies can be followed. A wider $\mathrm{Si} / \mathrm{Al}$ range may be investigated. In addition to that, modified zeolites, i.e. acid functionalized zeolites [2], can be used in order to increase the conductivity and the fuel cell performance.

In Chapter 5, micro-structured Nafion membranes were prepared using hot embossing technique and characterized for DMFC applications. Besides hot embossing, DE2020 Nafion dispersion was also cast on a micro-structured silicon mold. Unfortunately the adhesion between the membrane and the mold was strong and release of the membrane film from the mold was problematic. Two methods were tried to prevent this: (1) By vapor depositing perfluorinated octyltrichlorosilane (FOTS), surface of the silicon mold was chemically hydrophobized as a first method. (2) Membranes were immersed into water or alcohol to keep the membrane in a swollen state prior to release. Both methods didn't achieve easier release from the mold.

In addition to these, new methods can be tried to make micro-structured membranes with higher fuel cell performance. One of them could be first making a micro-structured membrane and then coating the micro- 
structured side of the membrane with catalyst layer. Dry techniques are desirable for catalyst coating the membrane in order to avoid swelling of the membrane. Sputtering can be a choice of a dry technique. In the case of DMFC, there are two major difficulties for this: (i) Finding the appropriate $\mathrm{Pt}-\mathrm{Ru}$ target for the anode and (ii) High loadings of the catalyst $\left(5 \mathrm{mg} / \mathrm{cm}^{2}\right)$, which is needed for high DMFC performance. The chance of getting cracks in the catalyst layer increases with increasing catalyst loading. This method is more appropriate for hydrogen fuel cells where lower loadings $\left(0.5 \mathrm{mg} / \mathrm{cm}^{2}\right)$ are used.

Another method can be hot embossing the micro-structure on the membrane together with the gas diffusion electrode (GDE). Instead of placing the membrane on the silicon mold and hot embossing, GDE can be placed in between the silicon mold and the membrane and in one step microstructure can be made and MEA can be prepared by hot pressing the GDE on the membrane. One difficulty of this process is the stability of the fibers of the gas diffusion layer (GDL). If the fibers are broken then the electrical conductivity of the material decreases and the performance of the MEA decreases as well. Hot embossing process parameters (temperature, pressure and time) have to be optimized to get the best structure and still keeping the fibers of the GDL intact.
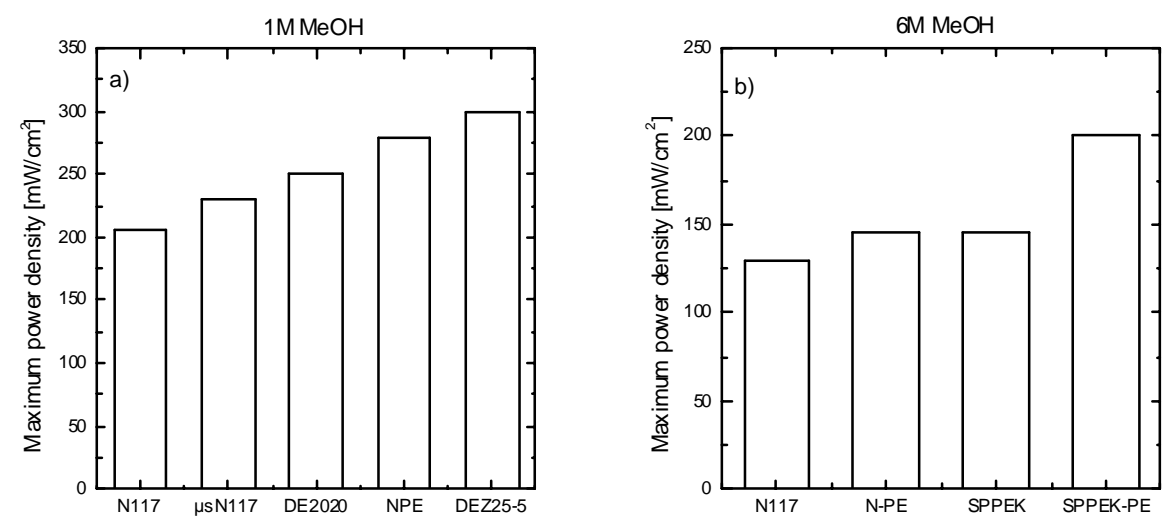

Figure 2. DMFC performances of various membranes at a) $1 \mathrm{M}$ and b) $6 \mathrm{M} \mathrm{MeOH}$ concentrations.

Figure $2 \mathrm{a}$ and $2 \mathrm{~b}$ summarizes the main findings of the DMFC measurements of this thesis. It hopefully gives indication in which direction the de- 
velopment of new DMFC membranes should go in the future. The performance of $\mu$ s N117 is higher than normal N117 membrane due to its lower methanol cross-over and higher polymer-catalyst interaction zone (Fig. 2a.). The solution cast membrane, DE2020, has higher DMFC performance than extruded one (N117) due to its higher ion-exchange capacity. The N-PE composite membrane performs better than pure DE2020 membrane due to its high dimensional stability, low methanol cross-over and reasonable proton conductivity. The composite membrane prepared by mixing DE2020 dispersion with H-ZSM-5 type zeolites has the best DMFC performance of all membranes studied in this thesis due to its lower methanol cross-over and higher proton conductivity.

Figure $2 \mathrm{~b}$ compares the DMFC performances at $6 \mathrm{M}$ methanol concentration. The performances of perfluorinated membranes (N117 and N-PE) are similar to SPPEK and lower than SPPEK-PE due to their significantly high methanol cross-over in comparison to SPPEK-PE composite membrane. SPPEK membrane has already low methanol cross-over and it is further decreased by impregnation into PE substrate. SPPEK-PE is the membrane of choice for DMFCs at high methanol concentrations. Depending on the operating conditions, the best membranes are composite (SPPEK-PE and N-PE) and hybrid (Nafion-Zeolite) membranes. It seems that composite membrane containing materials with optimized properties may be the future direction of development of membranes for DMFC. Combining the best characteristics in one membrane material increases the potential in developing a very good membrane for DMFC [3-6].

\section{References}

1. Santoso, F., Albrecht, W., Schroeter, M., Weigel, T., Paul, D. and Schomäcker, R., A Novel technique for preparation of aminated polymide membranes with microfiltration characterisatics. J. Membr. Sci., 2003. 223(9): p. 171.

2. Holmberg, B. A., Wang, X. and Yan, Y., Nanocomposite fuel cell membranes based on Nafion and acid functionalized zeolite beta nanocrystals. J. Membr. Sci., 2008. 320(1-2): p. 86.

3. Sancho, T., Lemus, J., Urbiztondo, M., Soler, J. and Pina, M. P., Zeolites and zeotype materials as efficient barriers for methanol 
cross-over in DMFCs. Microporous and Mesoporous Materials, 2008. 115: p. 206.

4. Chen, L. C., Yu, T. L., Lin, H. L. and Yeh, S. H., Nafion/PTFE and zirconium phosphate modified Nafion/PTFE composite membranes for direct methanol fuel cells. J. Membr. Sci., 2008. 307(1): p. 10.

5. Nasef, M. M., Zubir, N. A., Ismail, A. F., Khayet, M., Dahlan, K. Z. M., Saidi, H., Rohani, R., Ngah, T. I. S. and Sulaiman, N. A., PSSA pore-filled PVDF membranes by simultaneous electron beam irradiation: Preparation and transport characteristics of protons and methanol. J. Membr. Sci., 2006. 268(1): p. 96.

6. Su, Y.-H., Liu, Y.-L., Sun, Y.-M., Lai, J.-Y., Guiver, M. D. and Gao, Y., Using silica nanoparticles for modifying sulfonated poly(phthalazinone ether ketone) membrane for direct methanol fuel cell: A significant improvement on cell performance. Journal of Power Sources, 2006. 155(2): p. 111. 



\section{Summary}

This thesis describes the development of new membrane materials for DMFCs. Various strategies were employed:

- Impregnation of conductive polymer into a porous support to obtain composite membranes with low methanol crossover and long term stability

- Incorporation of inorganic fillers into the bulk phase of conductive polymer to increase the proton conductivity and at the same time decrease the methanol cross-over

- Surface micro-structuring of the conductive polymer by hot embossing to increase the effective catalytic surface area without increasing the geometric one.

In the first part of this thesis (Chapter 2 and 3), we focus on impregnation concept to develop low methanol permeable membranes for DMFCs.

In Chapter 2, 'Dimensionally stable Nafion-polyethylene composite membranes for direct methanol fuel cell applications', Nafion ${ }^{\circledR}$ impregnated Solupor ${ }^{\circledR}$, microporous UHMWPE film, (N-PE), Nafion ${ }^{\circledR} 117$ (N117) and a membrane prepared using a DE2020 Nafion ${ }^{\circledR}$ dispersion (DE2020) were prepared and characterized. Introducing Nafion ${ }^{\circledR}$ into the pores of Solupor ${ }^{\circledR}$ causes reduction of both methanol cross-over and proton conductivity. Low proton conductivity of the N-PE membrane is compensated by its significantly low methanol cross-over resulting to better DMFC performance at 1 and $6 \mathrm{M}$ concentrations in comparison to N117 and DE2020 membranes. Besides, N-PE composite membrane has high dimensional stability, low membrane thickness, good performance using less Nafion ${ }^{\circledR}$ ionomer, with reduced cost. In addition to the real fuel cell measurements, characteristic $\beta$ values of the membranes were also calculated using both thickness dependent and independent methods. All characteristic values failed to predict the real fuel cell performance and should be used with caution. 
In Chapter 3, 'Impregnated membranes for direct methanol fuel cells at high methanol concentrations', Sulfonated poly(phthalazinone ether ketone) (SPPEK) impregnated Solupor ${ }^{\circledR}$, microporous film, (SPPEK-PE) and pure SPPEK membranes with two different ion-exchange capacities (IECs), were prepared and characterized. Impregnating SPPEK into PE decreases swelling degree, methanol permeability and proton conductivity of the membranes.. Unlike perfluorinated membranes, SPPEK-PE shows an increase in its DMFC performance at high methanol concentration and that makes it more attractive for mobile DMFC applications where high methanol concentrations are needed to compete with Li-Ion batteries.

In the second part of this thesis (Chapter 4 and 5) we focus on modification of commercially available Nafion membranes (N117) and in house made solution cast Nafion membranes (DE2020).

\section{In Chapter 4, 'Nafion ${ }^{\circledR} / \mathrm{H}-Z S M-5$ composite membranes with superior performance for direct methanol fuel cells, solution cast composite di-} rect methanol fuel cell membranes (DEZ) based on DE2020 Nafion ${ }^{\circledR}$ dispersion and in house prepared H-ZSM-5 zeolites with different Si/Al ratios were investigated. All composite membranes have indeed lower methanol permeability and higher proton conductivity than pure DE2020 membrane. The composite membranes with $\mathrm{Si} / \mathrm{Al}$ ratio 25 and $5 \mathrm{wt} . \%$ of zeolites (DEZ25-5) having the lowest methanol permeability and the membrane with $\mathrm{Si} / \mathrm{Al}$ ratio 50 and $1 \mathrm{wt}$ \% of zeolites (DEZ50-1) having the highest proton conductivity are tested in the direct methanol fuel cell (DMFC) for several days. The DEZ25-5 membrane has the best performance; namely high power density and stable performance in time with low fluctuations.

In Chapter 5, 'Micro-structured Nafion membranes for direct methanol fuel cell applications', Nafion ${ }^{\circledR} 117$ (N117), heat and pressure treated (hp) N117 and micro-structured ( $\mu \mathrm{s})$ N117 membranes (prepared by hot embossing) are thoroughly characterized with respect to their swelling degree, methanol flux, membrane resistance and DMFC performance. Heat and pressure treatment during hot embossing probably makes the membrane structure more compact. This inhibits infiltration of water and methanol into the hydrophobic polymer zones harder and leads to decrease in water content and methanol flux for both hp N117 and $\mu$ s N117 membranes. 
Nonetheless, all three membranes have similar resistances. The densification of the structure for the hp N117 and $\mu$ s N117 membranes may facilitate transport of $\mathrm{H}^{+}$through them due to decrease of tortuosity. In the DMFC, the hp N117 has similar performance with normal N117 membrane despite its low methanol crossover. The $\mu \mathrm{s}$ N117, however, has better performance than normal N117 probably due to better catalyst utilization due to microstructure. In DMFC stacks, which contain multiple MEAs, this can lead to a higher power output gain and/or lower system volume. 



\section{Samenvatting}

Dit proefschrift beschrijft de ontwikkeling van nieuwe membraanmaterialen voor DMFC's. Verschillende strategieën zijn gevolgd:

- Het impregneren van geleidend polymeer in een poreuze drager om composietmembranen met een lage oversteek van methanol en een lange termijn stabiliteit te verkrijgen.

- Het gebruik van anorganische vulmiddelen in de bulk van het geleidende polymeer om de protongeleiding te verhogen en tegelijkertijd de oversteek van methanol te verminderen.

- Het aanbrengen van microstructuren aan het oppervlak van het geleidend polymeer door heet vervormen om de effectieve katalytische oppervlakte te vergroten zonder vergroting van de geometrie.

In het eerste gedeelte van dit proefschrift (Hoofdstuk 2 en 3) richten we ons op een impregnatieconcept om membranen voor DMFC's te ontwikkelen met lage methanolpermeabiliteit.

In hoofdstuk 2, "Dimensionally stable Nafion-polyethylene composite membranes for direct methanol fuel cell applications", met Nafion ${ }^{\circledR}$ geimpregneerd Solupor ${ }^{\circledR}$, microporeuze UHMWPE film (N-PE), Nafion ${ }^{\circledR} 117$ (N117) en een membraan geproduceerd met een DE2020 Nafion ${ }^{\circledR}$ dispersie zijn geprepareerd en gekarakteriseerd. Het inbrengen van Nafion ${ }^{\circledR}$ in de porieën van het Solupor ${ }^{\circledR}$ veroorzaakt een reductie van zowel methanoloversteek als protongeleiding. De lage protongeleiding van het N-PE membraan wordt gecompenseerd door de significant lage methanoloversteek, hetgeen resulteert in betere DMFC prestatie bij concentraties van 1 en $6 \mathrm{M}$ in vergelijking met N117 en DE2020 membranen. Overigens, het N-PE composiet membraan heeft een hoge dimensionele stabiliteit, lage membraandikte en een goede prestatie bij gebruik van minder Nafion ${ }^{\circledR}$ ionomeer en dus met lagere kosten. Naast de echte brandstofcelmetingen, zijn ook de karakteristieke -waarden van de membranen berekend, volgens beide, dikte afhankelijke en onafhankelijke, methoden. Met geen enkele waarde kon de echte brandstofcelprestatie voorspeld worden. Deze waarden dienen daarom waardes met voorzichtigheid gebruikt worden. 
In hoofdstuk 3, "Impregnated membranes for direct methanol fuel cells at high methanol concentrations", zijn, met gesulfoneerde poly(ftalazinone ether keton) (SPPEK) geïmpregneerd Solupor ${ }^{2}$, microporeuze film (SPPEK-PE), en pure SPPEK membranen geprepareerd en gekarakteriseerd. Impregnatie van PE met SPPEK verlaagt de zwellingsgraad, methanolpermeabiliteit en protongeleiding van de membranen. In tegenstelling tot geperfluoreerde membranen toont SPPEK-PE een verbetering in DMFC prestatie bij hoge methanolconcentratie en dat maakt dit aantrekkelijker voor mobiele DMFC-toepassingen, waar hoge methanolconcentraties nodig zijn, om te kunnen concurreren met Li-ion batterijen.

In het tweede deel van dit proefschrift (Hoofdstuk 4 en 5) richten we ons op modificatie van commercieel verkrijgbare Nafion-membranen (N117) en eigengemaakte, uit oplossing gegoten Nafion membranen (DE2020).

In hoofdstuk 4, zijn "Nafion ${ }^{\circledR} / \mathrm{H}-Z S M-5$ composiet membranen met superieure prestatie voor direct methanol brandstofcellen", uit oplossing gegoten composiet direct methanol brandstofcelmembranen (DEZ) gebaseerd op de DE2020 Nafion ${ }^{\circledR}$ dispersie en eigengemaakte H-ZSM-5 zeolieten met verschillende $\mathrm{Si} / \mathrm{Al}$ verhoudingen onderzocht. Alle composietmembranen hebben inderdaad een lagere methanolpermeabiliteit en hogere protongeleiding dan het pure DE2020-membraan. Het composiet-membraan met $\mathrm{Si} / \mathrm{Al}$ verhouding 25 en 5\% (massa) zeolieten (DEZ25-5) met de laagste methanolpermeabiliteit en het membraan met Si/Al verhouding 50 en $1 \%$ (massa) zeolieten (DEZ50-1) met de hoogste protongeleiding zijn getest in de direct methanol brandstofcel (DMFC) gedurende enkele dagen. Het DEZ25-5 membraan heeft de beste prestatie namelijk, een hoge vermogensdichtheid en stabiele prestatie in de tijd met kleine fluctuaties.

In hoofdstuk 5, "Micro-structured Nafion membranes for direct methanol fuel cell applications", zijn Nafion ${ }^{\circledR} 117$ (N117), hitte en drukbehandelde (hp) N117 en micro-gestructureerde ( $\mu \mathrm{s})$ N117 membranen (geprepareerd door aandrukken van een hete mal) grondig gekarakteriseerd wat betreft hun zwellingsgraad, methanolflux, membraanweerstand en DMFCprestatie. De hitte- en drukbehandeling tijdens aanbrengen van de microstructuur maakt de membraanstructuur waarschijnlijk meer compact. Dit 
verhindert indringen van het water en methanol in de hydrofobe polymeerzones meer en leidt tot een lager watergehalte en methanoltransport voor zowel hp N117 als us N117 membranen. Desalniettemin hebben alle 3 membranen vergelijkbare weerstanden. De verdichting van de structuur van de hp N117 en $\mu$ s N117 membranen zou $\mathrm{H}^{+}$transport in die membranen kunnen faciliteren vanwege een minder tortueuze structuur. In de DMFC heeft het hp N117 mebraan een prestatie vergelijkbaar met die van het normale N117 membraan, ondanks zijn lagere methanoloversteek. Het $\mu$ s N117 membraan daarentegen, vertoont een betere prestatie dan normaal $\mathrm{N} 117$, waarschijnlijk dank zij een betere katalysator-utilisatie veroorzaakt door de microstructuur. In DMFC stacks, die meerdere MEA's bevatten, kan dit leiden tot een hogere vermogensproductie en/of een lager systeemvolume. 



\section{Acknowledgements}

After four and a half years working on my master and $\mathrm{PhD}$ thesis, it is now time to say thank you to many people.

First of all, I'd like to thank my promoter Prof. Matthias Wessling, who has given me the chance to do my $\mathrm{PhD}$ at this wonderful group and on this great topic. Thank you Matthias for your encouragement and faith in me and on this project. Furthermore, I'd like to thank my professor from FH Steinfurt Prof. Volkmar Jordan, who has believed in me and sent me to Twente to do my master assignment here on monopolor electrodialysis membranes. Thank you Prof. Jordan without you, I could not be here writing these words.

My daily supervisor, my favorite supervisor (I know you are the only supervisor I have) Dimitris Stamatialis. Even if I thank you one million times it won't be enough for all your help, support, input, power of motivating me, patience and this list goes on like this for couple of more pages. Still, many many thanks Dimitris for everything. If I consider all your help and input, it won't be unfair if we share the 'Dr.' title I can give you the ' $\mathrm{D}$ ' and can get the ' $r$ ' for myself.

How can I forget my lovely supervisor, when I was doing my master assignment at Twente. We have had lots of fun and I had lots of training in the corridors of the Langezijds building. I was $65 \mathrm{~kg}$ at that time and it was with the help of you Joerg. Thank you very much for your help and support during my master and PhD work.

Since I have the chance, I also would like to thank Greet, the secretary of our group. I guess I was the one who has the most questions to you in the group history. Thank you for your patience and endless help Greet.

I also would like to use this opportunity to thank my students. Nilesh for his porous PEI films, Alex for his impregnation work, Anna for her zeolite study and Joost for his micro-structured membranes. Thank you guys, witout your contribution this thesis will not be complete.

I want to thank to the users committee members of my project (Dr. Gijs Calis, Ir. Harold Smelt, Dr. Bernd Bauer and Ir. Ronald Mallant) for the fruitful discussions and their suggestions concerning my work. 
I want to thank to my office mates as well. First we had offices in Langezijds and I shared the office with Tymen, Wilbert and Zeynep. And then we moved to Meander and I had new office mates: Karina, Joost and Wika. Thank you guys for the nice atmosphere and the friendly environment. I especially wanted to thank to Karina, but unfortunately I won't be able to do that. Why didn't you type at least one chapter of my thesis Karina, why?

I also would like to thank Rob and Kitty for their suggestions, all the EMI guys for their help on every scientific topic, My man Marcel for solving all kinds of computer problems (even the ones I created to bug him) and also lending his handsome son to help me with the typing phase of my $\mathrm{PhD}$, John for always having time for me and building all kinds of set-ups for not only me, but for all of us, Herman for his help on focusing on the images and usage of stigma (or whatever the name is, I can't even say it and he is using it), Harmen for electrodialysis problems, Antoine for social life and drinking problems, Zandrie for monthly computer virus delivery and weekly Turkish lessons, Erik (R) for his help and patience.

Of course we spent most of our time inside the langezijds or meander building, but we also went out. I'd like to thank all the Rauchen Group (Can, Mate, Jens, Maiky, Katja, Joao (additional thanks to you Dr. Andre for the thesis layouting), Jutta, Koray, Fuat, Karina, Srivatsa, Ikenna, Mayur and Jigar - Core group and the part-time members) for accepting me as a part of their group. Since I am not smoking, it was really hard to make them accept me, but I got in there in the end. We have shared good and bad, happy and sad stuff, long story short, we have shared life. Thank you guys for taking me in.

I would like to thank to my new colleagues as well for their encouragement and support during the writing phase. I'd like to thank to Erik, Stef, Martijn, Menno and all the others from NedStack. I also want to thank once more to Martijn for translating the summary in Dutch.

Last but not least, I would like to thank my wife Tugba and my family. Canlarim benim sizlerin sonsuz destegi olmasaydi ne bu gunlere gelebilirdim ne de bu guzel gunu yasayabilirdim. Canim esim Tugba, senin yaptigin o turk kahveleri, o motive edici sohbetlerin, o sabrin olmasaydi bu kadar stresin ustesinden gelemezdim. Askim, esim ve daima yanimda oldugun icin sana sonsuz tesekkurler. Seni canimdan cok seviyorum. Ve tabiki canim annem ve babam Nedret ve Huseyin YILDIRIM. Guzellerim benim 
sizlerin sayesinde bu yaslara geldim, bu okullari okudum, yurt disina sizin fedakarliklarinizla cikabildim. Eger bu mutlu gunu burada birlikte yasayabiliyorsak bu sizin ve tabiki Tugbamin sayesin. Iyi ki varsiniz iyi ki benim ailmesiniz. Sizleri canimdan cok seviyorum hersey icin sonsuz tesekkur ediyorum. Tabi Mustafa babam ve Mukerem anneme de verdikleri destek ve gosterdikleri sevgi icin sonsuz tesekkurler ediyorum. Esim ve buyuk ailem; sizler beni cok mutlu ettiniz umarim sizler de en az benim kadar mutlu olursunuz. HERSEY ICIN SONSUZ TESEKKURLER.

Hakan 
